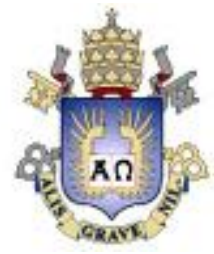

Alan Costa Carneiro Silva

\title{
Avaliação de Maturidade do Processo de Gestão Estratégica em Entidades Públicas Federais
}

Dissertação de Mestrado

Dissertação apresentada ao Programa de PósGraduação em Administração de Empresas da PUCRio como requisito parcial para obtenção do grau de Mestre em Administração de Empresas.

Orientadora: Profa. Maria Angela Campelo de Melo 


\section{Pontifícia $U_{\text {Miversidade }}$ C Atólica

\section{Alan Costa Carneiro Silva}

\section{Avaliação de Maturidade do Processo de Gestão Estratégica em Entidades Públicas \\ Federais}

Dissertação apresentada como requisito parcial para obtenção do grau de Mestre pelo Programa de PósGraduação em Administração de Empresas do Departamento de Administração da PUC-Rio. Aprovada pela Comissão Examinadora abaixo assinada.

Profa. Maria Angela Campelo de Melo

Orientadora

Departamento de Administração - PUC-Rio

Profa. Teresia Diana Lewe van Aduard de Macedo

Soares

Departamento de Administração - PUC-Rio

Prof. Joaquim Rubens Fontes Filho

FGV

Prof ${ }^{\text {. }}$. Mônica Herz

Vice-Decana de Pós-Graduação do CCS - PUC-Rio

Rio de Janeiro, 10 de maio de 2017 
Todos os direitos reservados. É proibida a reprodução total ou parcial do trabalho sem autorização da universidade, do autor e do orientador.

\section{Alan Costa Carneiro Silva}

Graduação em Administração Pública e de Empresas pela Fundação Getúlio Vargas (2012). Analista de Planejamento, Gestão e Infraestrutura em Informações Geográficas e Estatísticas no Instituto Brasileiro de Geografia e Estatística (IBGE).

Ficha Catalográfica

\section{Silva, Alan Costa Carneiro}

Avaliação de maturidade do processo de gestão estratégica em entidades públicas federais / Alan Costa Carneiro Silva ; orientadora: Maria Angela Campelo de Melo. - 2017.

$$
126 \text { f. : il. color. ; } 30 \mathrm{~cm}
$$

Dissertação (mestrado)-Pontifícia Universidade Católica do Rio de Janeiro, Departamento de Administração, 2017.

Inclui bibliografia

1. Administração - Teses. 2. Gestão estratégica. 3. Avaliação de maturidade. 4. Gestão estratégica em organizações públicas federais. I. Melo, Maria Angela Campelo de. II. Pontifícia Universidade Católica do Rio de Janeiro. Departamento de Administração. III. Título.

CDD: 658 
Para meus pais, Sandra e

Carlos e minha noiva, Manuela, pelo apoio e confiança. 


\section{Agradecimentos}

À Professora Maria Angela Campelo de Melo pela empatia e orientação, sem as quais não teria sido possível o desenvolvimento deste trabalho;

Aos respondentes das entidades públicas federais analisadas, pela disposição em contribuir com este trabalho;

Aos meus gestores da Fundação Instituto Brasileiro de Geografia e Estatística IBGE, que, na medida do possível, foram flexíveis, possibilitando a conciliação das minhas demandas acadêmicas com as demandas profissionais;

À Coordenação Central de Pós-Graduação da PUC e à Coordenação de Aperfeiçoamento de Pessoal de Nível Superior - CAPES pelas bolsas concedidas;

Aos professores que contribuíram com o desenvolvimento desta pesquisa, através de críticas, elogios e sugestões;

À minha família e aos meus amigos, que me auxiliaram e motivaram para a realização deste trabalho;

Ao Presidente e Chief Executive Officer do Balanced Scorecard Institute, Howard Rohm, pela resposta enviada sobre a questão metodológica do Strategic Management Maturity Model;

Aos membros da Banca Examinadora, que aceitaram dedicar seu tempo e seus conhecimentos para julgar e aprimorar este trabalho. 


\section{Resumo}

Silva, Alan Costa Carneiro; Campelo, Maria Angela Campelo (Orientadora). Avaliação de Maturidade do Processo de Gestão Estratégica em Entidades Públicas Federais. Rio de Janeiro, 2017. 126p. Dissertação de Mestrado - Departamento de Administração, Pontifícia Universidade Católica do Rio de Janeiro.

As organizações públicas, como gestoras de recursos públicos, devem pautar suas ações em princípios relativos à eficiência, eficácia e efetividade. Ciente de tal necessidade, as antigas filosofias de gestão dos bens públicos foram alteradas, a partir da introdução do conceito de New Public Management. Com a adoção dessa nova forma de gestão da coisa pública, permitiu-se a apropriação de um conceito anteriormente utilizado somente na iniciativa privada, conhecido como gestão estratégica. Esse tipo de gestão permite que as organizações, de forma sistêmica e contínua, planejem, monitorem e avaliem as ações estratégicas visando o alcance dos seus objetivos. Pela importância do processo de gestão estratégica ligado às organizações públicas, este estudo tem como objetivo principal a avaliação do nível de maturidade do processo de gerenciamento estratégico nas entidades públicas federais estudadas de forma a subsidiar os gestores com informações úteis para a melhoria do processo e da tomada de decisão cotidiana. Para esse propósito, o Strategic Management Maturity Model $^{\mathrm{TM}}$, desenvolvido pela consultoria norte-americana Balanced Scorecard Institute, foi selecionado e adaptado, possibilitando a formulação do questionário de pesquisa, aplicado em 12 respondentes, quatro por instituição pública federal. Tal instrumento, possibilitou a análise e a indicação do nível de maturidade das oito dimensões presentes no modelo, mesmo que sem validade estatística, de forma individual e conjunta, representando o processo de gestão estratégica.

\section{Palavras-chave}

Gestão estratégica; avaliação de maturidade; gestão estratégica em organizações públicas federais. 


\section{Abstract}

Silva, Alan Costa Carneiro; Campelo, Maria Angela Campelo (Advisor). Maturity Assessment of the Strategic Management Process in Federal Public Entities. Rio de Janeiro, 2017. 126p. Dissertação de Mestrado Departamento de Administração, Pontifícia Universidade Católica do Rio de Janeiro.

Public organizations, as managers of public resources, should guide their actions in terms of efficiency, efficacy and effectiveness. Aware of such need, the old philosophies of public management were altered, from the introduction of the concept of New Public Management. With the adoption of this new way of managing the public thing, it was allowed the appropriation of a concept previously used only in the private initiative, known as strategic management. This type of management allows organizations, in a systemic and continuous way, to plan, monitor and evaluate the strategic actions aiming the achievement of its objectives. Due to the importance of the strategic management process related to public organizations, this study will have as main objective the evaluation of the maturity level of the strategic management process in the federal public entities studied in order to subsidize managers with useful informations to improve the process and the decision-making process on a daily basis. For this purpose, the Strategic Management Maturity Model ${ }^{\mathrm{TM}}$, developed by a well-known american consultancy called Balanced Scorecard Institute, was selected and adapted, enabling the formulation of the research questionnaire, applied in 12 respondents, four by federal public institution. This instrument made possible to analyze and indicate the level of maturity of the eight dimensions present in the model, even without statistical validity, individually and jointly, representing the strategic management process.

\section{Keywords}

Strategic management; maturity assessment; strategic management in federal public organizations. 


\section{Sumário}

1 Introdução 16

$\begin{array}{ll}\text { 1.1. Problema de Pesquisa } & 17\end{array}$

1.2. Objetivos 18

1.3. Delimitações de Escopo 18

$\begin{array}{ll}\text { 1.4. Estrutura da Dissertação } & 19\end{array}$

2 Referencial Teórico $\quad 21$

2.1. Administração Pública $\quad 21$

2.1.1. O Modelo Gerencial de Administração Pública 25

2.1.2. Boas Práticas de Gestão em Órgãos e Entidades

Públicas Brasileiras 26

2.2. Gestão Estratégica 29

2.3. Avaliação de Maturidade em Gestão Estratégica 33

2.3.1. Strategic Management Maturity Model ${ }^{\mathrm{TM}} 35$

2.3.1.1. Liderança 38

2.3.1.2. Cultura e Valores 40

2.3.1.3. Pensamento Estratégico e Planejamento 42

2.3.1.4. Alinhamento 46

2.3.1.5. Mensuração de Desempenho 47

2.3.1.6. Gerenciamento de Desempenho 50

2.3.1.7. Melhoria de Processos 52

2.3.1.8. Sustentabilidade do Gerenciamento Estratégico 55

3 Metodologia 58

3.1. Delineamento da Pesquisa 58

3.2. Procedimentos de Coleta e Tratamento de Dados 61

3.3. Procedimentos de Análise de Dados 63

4 Avaliação do Nível de Maturidade em Gestão Estratégica das Organizações Estudadas 
4.1. Caracterização das Organizações Analisadas

65

4.2. Análise Comparativa dos Resultados por Dimensão 66

4.2.1. Liderança 67

4.2.2. Cultura e Valores 71

4.2.3. Pensamento Estratégico e Planejamento 75

4.2.4. Alinhamento 80

4.2.5. Mensuração de Desempenho 83

4.2.6. Gerenciamento de Desempenho 87

4.2.7. Melhoria de Processos 91

4.2.8. Sustentabilidade do Gerenciamento Estratégico 95

4.3. Análise Comparativa dos Resultados em Gestão

Estratégica 99

5 Conclusão 104

$\begin{array}{ll}\text { Referências bibliográficas } & 107\end{array}$

$\begin{array}{ll}\text { Anexo } & 112\end{array}$

Anexo A - Tradução do Questionário do Strategic Management Maturity Model ${ }^{\mathrm{TM}} \quad 112$

Anexo B - Transcrição de E-mail enviado por Howard Rohm 115

$\begin{array}{ll}\text { Apêndice } & 116\end{array}$

Apêndice A - Questionário de Pesquisa 116 


\section{Lista de figuras}

Figura 1 - Sistema de Gestão Pública $\quad 27$

Figura 2 - Dimensões e níveis de maturidade em gestão

estratégica 36

Figura 3 - Delineamento da pesquisa 60 


\section{Lista de quadros}

Quadro 1 - Definições e características das entidades públicas pertencentes à administração indireta 23

Quadro 2 - Princípios administrativos 24

Quadro 3 - Características das fases da Administração Pública 26

Quadro 4 - Definições de estratégia 30

Quadro 5 - Definições de gestão estratégica 32

Quadro 6 - Níveis de maturidade em gestão estratégica 37

Quadro 7 - Boas práticas em Liderança 39

Quadro 8 - Boas práticas em Cultura e Valores 42

Quadro 9 - Boas práticas em Pensamento Estratégico e

Planejamento 45

Quadro 10 - Boas práticas no Alinhamento 46

Quadro 11 - Boas práticas na Mensuração de Desempenho 49

Quadro 12 - Boas práticas no Gerenciamento de Desempenho 51

Quadro 13 - Boas práticas em Melhoria de Processos 54

Quadro 14 - Boas práticas na Sustentabilidade do

Gerenciamento Estratégico $\quad 56$

Quadro 15 - Níveis de maturidade Intra-Dimensão 63

Quadro 16 - Níveis de maturidade em gestão estratégica 64

Quadro 17 - Principais dificuldades na dimensão Liderança 68

Quadro 18 - Soluções de melhorias na dimensão Liderança $\quad 70$

Quadro 19 - Principais dificuldades na dimensão Cultura e

Valores

Quadro 20 - Soluções de melhorias na dimensão Cultura e

Valores

Quadro 21 - Principais dificuldades na dimensão Pensamento

Estratégico e Planejamento

Quadro 22 - Soluções de melhorias na dimensão Pensamento

Estratégico e Planejamento $\quad 79$

Quadro 23 - Principais dificuldades na dimensão Alinhamento 81

Quadro 24 - Soluções de melhorias na dimensão Alinhamento 82 
Quadro 25 - Principais dificuldades na dimensão Mensuração de Desempenho

Quadro 26 - Soluções de melhorias na dimensão Mensuração de Desempenho

Quadro 27 - Principais dificuldades na dimensão

Gerenciamento de Desempenho

Quadro 28 - Soluções de melhorias na dimensão

Gerenciamento de Desempenho

Quadro 29 - Principais dificuldades na dimensão Melhoria de

Processos

Quadro 30 - Soluções de melhorias na dimensão Melhoria de

Processos

Quadro 31 - Principais dificuldades na dimensão

Sustentabilidade do Gerenciamento Estratégico

Quadro 32 - Soluções de melhorias na dimensão

Sustentabilidade do Gerenciamento Estratégico

Quadro 33 - Níveis de maturidade em gestão estratégica conforme os respondentes da unidade de gerenciamento estratégico

Quadro 34 - Níveis de maturidade em gestão estratégica conforme os respondentes das demais áreas das organizações 


\section{Lista de tabelas}

Tabela 1 - Respostas dos questionários na dimensão Liderança

Tabela 2 - Respostas dos questionários na dimensão Cultura e Valores

Tabela 3 - Respostas dos questionários na dimensão

Pensamento Estratégico e Planejamento

Tabela 4 - Respostas dos questionários na dimensão

Alinhamento

Tabela 5 - Respostas dos questionários na dimensão

Mensuração de Desempenho

Tabela 6 - Respostas dos questionários na dimensão

Gerenciamento de Desempenho

Tabela 7 - Respostas dos questionários na dimensão Melhoria de Processos

Tabela 8 - Respostas dos questionários na dimensão

Sustentabilidade do Gerenciamento Estratégico

Tabela 9 - Nível de maturidade em gestão estratégica 


\section{Abreviaturas e siglas}

ANCINE

Agência Nacional do Cinema

ANVISA

Agência Nacional de Vigilância Sanitária

BB

Banco do Brasil S.A.

BCB

Banco Central do Brasil

BNDES

Banco Nacional de Desenvolvimento Econômico e Social

BPM

Business Process Management

BPM CBOK

Business Process Management Common Body of Knowledge

BPMN

Business Process Model Notation

BSI

Balanced Scorecard Institute

CEF

Caixa Econômica Federal

CEO

Chief Executive Officer

$\mathrm{CMB}$

Casa da Moeda do Brasil

CMM

Capability Maturity Model

CNJ

Conselho Nacional de Justiça

CNPq

Conselho Nacional de Desenvolvimento Científico e Tecnológico

ECT

Empresas Brasileira de Correios e Telégrafos

Eletrobras

Centrais Elétricas Brasileiras S.A.

IBGE

Fundação Instituto Brasileiro de Geografia e Estatística

INCRA

Instituto Nacional de Colonização e Reforma Agrária

IPEA

Instituto de Pesquisa Econômica Aplicada

FUNASA

Fundação Nacional da Saúde

MPF

Ministério Público Federal

MP

Ministério do Planejamento, Desenvolvimento e Gestão

NPM

New Public Management

$S M M M^{\mathrm{TM}}$

Strategic Management Maturity Mode/ ${ }^{\mathrm{TM}}$ 
SUSEP

PDRAE

Petrobras

TIC
Superintendência de Seguros Privados

Plano Diretor de Reforma do Aparelho do Estado

Petróleo Brasileiro S.A.

Tecnologia da Informação e Comunicação 


\section{1 \\ Introdução}

As organizações, independentemente de tamanho, estrutura de propriedade, ou nível de internacionalização, atuam em um ambiente altamente incerto, sistêmico e complexo (SANTOS, 2011). Nesse universo de instituições, destacam-se o conjunto de organizações públicas, por sua finalidade de atendimento ao interesse público e por sua atuação ora como ator, ora como regulador do sistema. Essas instituições advêm da descentralização ou desconcentração das competências administrativas pertencentes ao Estado, devendo pautar suas ações em princípios constitucionais explícitos (legalidade, impessoalidade, moralidade, publicidade e eficiência) e em princípios implícitos, que incluem, dentre outros, os conceitos de eficácia e efetividade.

Objetivando melhorar a qualidade da gestão dos recursos públicos, alcançando padrões mais altos dos princípios acima mencionados, foi desenvolvido o modelo de gestão intitulado New Public Management - NPM, como um contraponto aos antigos modelos de gestão dos bens públicos. O NPM tem como filosofia a adaptação e transferência de conhecimentos e técnicas gerenciais do setor privado para o setor público, baseando-se em critérios como accountability, competição, controle de resultados e redução do tamanho e dos custos da máquina pública (PECI, PIERANTI e RODRIGUES, 2008).

Inicialmente desenvolvido pelo setor privado em grandes corporações, o conceito de gestão é entendido como o ato de administrar recursos. Essa gestão de recursos é atribuída, pelos acionistas, aos executivos da firma, contratados por aqueles para agir em seu nome. Uma questão a ser tratada aqui é como esse conceito pode ser apropriado para a utilização em organizações públicas? (LANE e WALLIS, 2009).

Ao contrário da origem do conceito de gestão, o conceito de estratégia teve seu desenvolvimento em instituições públicas, mais especificamente as organizações militares, nas quais era entendido como a ação de comandar ou conduzir exércitos em tempo de guerra (GHEMAWAT, 2000). Esse conceito foi 
apropriado pela área de administração visando melhorar o desempenho das organizações e, não obstante possua definições muito diversificadas, dispõe de palavras-chaves que ajudam a sintetizar esse conceito, sendo elas competitividade, mudanças, desempenho, posicionamento, missão, objetivos, resultados, integração, adequação organizacional (CAMARGOS e DIAS, 2003).

Os conceitos de gestão e estratégia, fundidos, deram origem ao conceito de gestão estratégica, que pode ser definido como um processo sistêmico e contínuo, que visa o planejamento, a execução e o acompanhamento das ações estratégicas definidas por uma dada organização visando o atingimento de seus objetivos. Esse conceito é entendido como uma forma de gestão que auxilia as organizações em geral, inclusive as públicas, a pensarem de forma estruturada e inovativa, possibilitando um salto de qualidade na gestão dos recursos.

\section{1. Problema de Pesquisa}

A necessidade da utilização e do aprimoramento do processo de gestão estratégica como forma de administrar as organizações vem aumentando por ser essencial o acompanhamento das ações estratégicas previstas na fase de planejamento de forma contínua e sistêmica. Essa exigência deve-se ao aumento da competitividade nos mercados, ao aumento da incerteza global e, no caso de organizações públicas, à maior pressão exercida pela sociedade por uma gestão pública profissional e adaptável às demandas em constante mudança.

Entretanto, conforme pacificado na literatura de mapeamento de processos, antes da aplicação de medidas corretivas visando o aprimoramento de um dado processo, deve-se, primeiro, conhecer sua estrutura e pontos críticos.

Apesar da relevância do tema, existe na literatura pouca pesquisa científica sobre a avaliação da maturidade em gestão estratégica. Os estudos sobre avaliação de maturidade têm se focado em processos e projetos prioritariamente voltados à área de Tecnologia da Informação e Comunicação - TIC. Ademais, não foram encontrados estudos científicos sobre o tema, se consideradas as organizações públicas como ponto focal de observação.

Por essa razão, esse estudo foca a análise do processo já existente, buscando responder às seguintes perguntas: 
- Qual é o nível de maturidade do processo de gestão estratégica, e das dimensões que o compõe, nas entidades públicas federais estudadas?

- Quais são as principais dificuldades e soluções de melhorias encontradas nas instituições estudadas? Esses pontos se repetem?

- Essas instituições possuem níveis semelhantes ou dessemelhantes de maturidade?

\section{2.}

\section{Objetivos}

Este estudo possui como objetivo geral:

- Avaliar o nível de maturidade do processo de gestão estratégica nas entidades públicas federais estudadas, de forma a subsidiar os gestores com informações úteis para a melhoria do processo e da tomada de decisão.

Como objetivos específicos, pretende-se:

- Desenvolver ou adaptar um modelo que permita a avaliação de maturidade do processo de gestão estratégica;

- Avaliar as dimensões que fazem parte do processo de gestão estratégica de forma individualizada e global;

- Identificar e categorizar as principais dificuldades e as soluções de melhorias indicadas pelos respondentes participantes nas dimensões analisadas;

- Analisar, comparativamente, os resultados obtidos, tanto em relação às dimensões, quanto em relação às entidades.

\section{3.}

\section{Delimitações de Escopo}

O presente estudo volta-se para o processo de gestão estratégica, mais especificamente em entidades públicas federais brasileiras, tendo como ponto principal a avaliação de maturidade desse processo nas organizações pesquisadas. No âmbito dessas avaliações, as informações são cruzadas buscando a análise das dimensões que fazem parte da gestão estratégica de forma, primeiramente, 
individualizada - em que são observadas, dentre outras questões, as principais dificuldades e soluções de melhorias, assim como as semelhanças nos processos examinados e, posteriormente, de forma global, pela qual se busca avaliar o nível de maturidade no processo de gestão estratégica nas organizações pesquisadas.

Diante do exposto e do foco desse estudo, é relevante ressaltar as seguintes delimitações de escopo:

- Esta dissertação aborda apenas organizações públicas classificadas como fundações, autarquias e empresas públicas. As empresas privadas e as sociedades de economia mista não são alvo de análise, devido à participação de capital privado em sua estrutura de propriedade. Os órgãos públicos, participantes da Administração Direta, também não são foco dessa análise, pois não possuem autonomia administrativa e financeira, nem a titularidade e execução de determinado serviço público. Logo, as expressões utilizadas nesse trabalho, como organizações públicas, instituições públicas, entidades públicas consideram apenas os três tipos de organizações destacadas.

- São alvos do estudo apenas instituições do governo federal. As especificidades, no que tange à gestão estratégica, de cada estado ou município, poderiam alterar o nível de maturidade encontrado, dificultando a análise comparativa dos resultados.

- Nesta dissertação, são abordadas apenas entidades públicas brasileiras. Assim como a justificativa do tópico acima, as especificidades, no que tange à gestão estratégica, de cada país poderiam alterar o nível de maturidade encontrado, dificultando a análise comparativa dos resultados.

\section{4.}

\section{Estrutura da Dissertação}

Esta dissertação está organizada em 5 capítulos. O Capítulo 1, introdutório, apresenta o problema de pesquisa, os objetivos do estudo, a delimitação de escopo e este tópico referente à estrutura da dissertação. O Capítulo 2 é dividido em três seções. Na primeira, são tratados, de forma sumária, os conceitos relacionados à Administração Pública, a evolução conceitual no que diz respeito aos modelos de 
gestão utilizados pela Administração Pública, e as boas práticas atualmente utilizadas pelas organizações públicas no que tange ao processo de gestão. $\mathrm{Na}$ segunda parte, é dado foco no processo de gestão estratégica, apresentando, dentre outras informações, diversos conceitos para estratégia e gestão estratégica. Além disso, é discutida nessa seção a avaliação de maturidade no processo de gestão estratégica. Na última seção desse Capítulo, o modelo utilizado como base para este estudo é explicado e complementado com contribuições de diversos autores. O Capítulo 3 tem como objetivo discorrer sobre o tipo de pesquisa, as organizações selecionadas e seus respectivos respondentes e o procedimento adotado para a análise das informações, dentre outros aspectos metodológicos importantes para a consecução deste estudo. No Capítulo 4, os resultados são descritos e analisados, inicialmente, por dimensão e, posteriormente, de forma global, envolvendo o processo de gestão estratégica como um todo. O Capítulo 5 apresenta a conclusão, incluindo as limitações e as oportunidades de estudos futuros sobre a temática abordada no estudo. 


\section{2 Referencial Teórico}

Este Capítulo subdivide-se em três seções. Na primeira, que discorre sobre a Administração Pública, são apresentados os conceitos básicos referentes a essa temática, a evolução histórica dos modelos de gestão pública, em termos de melhorias nas práticas de gestão e o Modelo de Excelência em Gestão Pública MEGP (BRASIL, 2014), desenvolvido pelo Ministério do Planejamento, Desenvolvimento e Gestão - MP, com base no paradigma da administração pública gerencial. Já na segunda seção, que trata da gestão estratégica, discute-se o surgimento desse conceito, suas definições, sua interligação com a gestão pública e a avaliação de maturidade no gerenciamento estratégico. Na última seção, são apresentadas as dimensões que afetam a gestão estratégica, segundo o Strategic Management Maturity Model ${ }^{\mathrm{TM}}$ - SMMM ${ }^{\mathrm{TM}}$, escolhido como base para a avaliação realizada neste trabalho. Para a realização deste referencial teórico foram utilizados materiais disponíveis até novembro de 2016.

\section{1. \\ Administração Pública}

Antes da definição do conceito de Administração Pública, é interessante que as funções atribuídas a cada um dos Poderes de Estado sejam entendidas. Conforme descrito por Carvalho Filho (2015), as funções estatais estão distribuídas, de forma preponderante, mas não exclusiva, entre os Poderes Legislativo (função normativa ou legislativa); Executivo (função administrativa); e Judiciário (função legislativa). Ainda segundo o autor, enquanto o ponto central da função legislativa está na criação de novas normas de direito e o da função judiciária na resolução de litígios, a função administrativa tem como foco a gestão dos interesses coletivos nas mais variadas dimensões.

Segundo Di Pietro (2013), o conceito de Administração Pública é mais comumente utilizado em dois sentidos: 
a) Em sentido objetivo, material ou funcional, ele designa a natureza da atividade exercida pelos sujeitos. Nesse sentido, portanto, focase na função administrativa imputada.

b) Em sentido subjetivo, formal ou orgânico, ele compreende as pessoas jurídicas, órgãos e agentes públicos que têm a incumbência de exercer uma das funções da atividade estatal, a função administrativa. Esse sentido, portanto, foca-se nos atores que realizam as obrigações administrativas estatais.

No sentido objetivo, as atividades exercidas pela administração pública abrangem o fomento, incentivo à iniciativa privada de utilidade pública; a polícia administrativa, atividade de execução das restrições impostas por lei ao exercício de direitos individuais em benefício do interesse coletivo; o serviço público, toda atividade que a Administração Pública executa para satisfazer à necessidade coletiva; e a intervenção, regulamentação e fiscalização da atividade econômica de natureza privada, bem como a atuação direta do Estado no domínio econômico.

Já no sentido subjetivo, as instituições que compõem o Estado visando à execução da função administrativa, podem ser divididas em dois subconjuntos:

a) Administração Direta. Decorrente do fenômeno de desconcentração do Estado, pelo qual a prestação de um determinado serviço público é feito de forma direta pelo Estado, através da criação de órgãos públicos. Não pressupõe a criação de uma nova pessoa jurídica.

b) Administração Indireta. Decorrente do fenômeno de descentralização do Estado, em qual a prestação de um determinado serviço público é feita de forma indireta pelo Estado, por meio da criação de autarquias, fundações, empresas públicas ou sociedades de economia mista. Pressupõe a criação de uma nova pessoa jurídica, que receberá da pessoa jurídica pública (União, Estados ou Municípios) a titularidade e a execução do serviço público, possuindo autonomia administrativa e financeira.

Conforme explicitado por Alexandrino e Paulo (2015), a Constituição Federal de 1988 e diversos dispositivos legais tratam da conceituação e diferenciação entre autarquias, empresas públicas, sociedades de economia mista e fundações públicas. Apesar de apresentarem diversas características distintivas, pode-se 
definir essas entidades e sumariar suas principais características, conforme indicado no Quadro 1.

Quadro 1 - Definições e características das entidades públicas pertencentes à administração indireta

Entidades Públicas $\quad$ Descrição

\begin{tabular}{|c|c|}
\hline Autarquias & $\begin{array}{l}\text { Serviço autônomo, criado por lei, com personalidade jurídica de direito público, } \\
\text { patrimônio e receita próprios para executar atividades típicas da Administração } \\
\text { Pública, que requeiram, para seu melhor funcionamento, gestão administrativa e } \\
\text { financeira descentralizada. Além disso, essas instituições não se submetem ao } \\
\text { regime falimentar e seus bens são impenhoráveis. Exemplos: Banco Central do } \\
\text { Brasil - BCB; Agência Nacional do Cinema - ANCINE; e Agência Nacional de } \\
\text { Vigilância Sanitária - ANVISA. }\end{array}$ \\
\hline Fundações & $\begin{array}{l}\text { Entidades criadas para a prestação de atividades de interesse público, sem fins } \\
\text { lucrativos, em áreas como saúde, educação, assistência social e produção científica, } \\
\text { podendo ser de direito público - assemelhando-se às autarquias - ou privado, com } \\
\text { patrimônio próprio, autonomia financeira e administrativa. Tais quais as } \\
\text { autarquias, não se submetem ao regime falimentar e seus bens são impenhoráveis. } \\
\text { Exemplos: Fundação Instituto Brasileiro de Geografia e Estatística - IBGE; } \\
\text { Fundação Nacional da Saúde - FUNASA; Conselho Nacional de Desenvolvimento } \\
\text { Científico e Tecnológico - CNPq. }\end{array}$ \\
\hline Empresas Públicas & $\begin{array}{l}\text { Entidades criadas por meio de autorização legislativa, com personalidade jurídica } \\
\text { de direito privado, com patrimônio próprio e autonomia financeira e } \\
\text { administrativa, para prestar serviço público ou explorar atividade econômica, } \\
\text { podendo adotar qualquer forma societária, possuindo em sua estrutura capital } \\
\text { inteiramente público. Ao contrário das autarquias e fundações, seus bens são } \\
\text { penhoráveis, não gozam de nenhum benefício fiscal não extensivo ao setor } \\
\text { privado. } \\
\text { Exemplos: Banco Nacional de Desenvolvimento Econômico e Social - BNDES; } \\
\text { Caixa Econômica Federal - CEF; Casa da Moeda do Brasil - CMB; e Empresa } \\
\text { Brasileira de Correios e Telégrafos - ECT. }\end{array}$ \\
\hline $\begin{array}{c}\text { Sociedades de } \\
\text { Economia Mista }\end{array}$ & $\begin{array}{l}\text { Criadas por meio de autorização legislativa para prestar serviços públicos ou } \\
\text { explorar a atividade econômica, possuem personalidade jurídica de direito privado, } \\
\text { patrimônio próprio e autonomia financeira e administrativa. Tais quais, as } \\
\text { empresas públicas, possuem bens penhoráveis e não gozam de nenhum benefício } \\
\text { fiscal não extensivo ao setor privado. Tem como principais diferenças em relação } \\
\text { às empresas públicas: capital misto, público e privado, em sua estrutura de } \\
\text { propriedade, com controle acionário por parte da Administração Pública; e } \\
\text { possibilidade de adotar somente a forma jurídica de Sociedade Anônima (S.A.). } \\
\text { Exemplos: Petróleo Brasileiro S.A. - Petrobras; Banco do Brasil S.A. - BB; e } \\
\text { Centrais Elétricas Brasileiras S.A. - Eletrobras. }\end{array}$ \\
\hline
\end{tabular}

Fonte: Elaborado pelo autor com base em Alexandrino e Paulo (2015). 
Conforme Carvalho Filho (2015), no âmbito do Direito Administrativo, definido como "o conjunto de normas e princípios que, visando sempre o interesse público, regem as relações jurídicas entre as pessoas e órgãos do Estado e entre este e as coletividades a que devem servir", uma série de princípio que orientam as ações das entidades participantes da Administração Pública é evidenciada. Esses princípios podem ser expressos ou explícitos (caso apareçam no texto da Constituição Federal); ou reconhecidos ou implícitos (caso, embora não descritos no texto da Constituição Federal, sejam reconhecidos pela doutrina e jurisprudência). Os princípios reconhecidos ou implícitos podem sofrer variações dependendo do autor que os enumera. Os princípios e suas definições, de forma ampla, são evidenciados no Quadro 2. Vale ressaltar que os cinco primeiros são expressos e os demais, reconhecidos.

Quadro 2 - Princípios administrativos

\begin{tabular}{|c|c|}
\hline Princípios & Descrição \\
\hline Legalidade & $\begin{array}{l}\text { Qualquer atividade administrativa deve ser autorizada por lei. Caso contrário, a } \\
\text { atividade é ilícita. }\end{array}$ \\
\hline Impessoalidade & $\begin{array}{l}\text { A Administração Pública deve dispensar aos administrados que se encontram em } \\
\text { igual situação jurídica tratamento igualitário. }\end{array}$ \\
\hline Moralidade & O Administrador Público não pode dispensar os preceitos éticos em sua conduta. \\
\hline Publicidade & $\begin{array}{l}\text { Os atos da Administração Pública devem ter a mais ampla divulgação possível } \\
\text { entre os administrados. }\end{array}$ \\
\hline Eficiência & $\begin{array}{l}\text { A Administração Pública e seus agentes devem ser produtivos e econômicos, } \\
\text { objetivando reduzir os desperdícios de dinheiro público. }\end{array}$ \\
\hline $\begin{array}{l}\text { Supremacia do Interesse } \\
\text { Público }\end{array}$ & Em caso de conflito, o interesse público deve prevalecer sobre o privado. \\
\hline Autotutela & A Administração Pública deve rever seus atos quando ilegais ou inconvenientes. \\
\hline Indisponibilidade & $\begin{array}{l}\text { A Administração Pública não dispõe dos bens públicos e interesses públicos, pois } \\
\text { atua em nome da coletividade. }\end{array}$ \\
\hline $\begin{array}{l}\text { Continuidades dos } \\
\text { Serviços Públicos }\end{array}$ & $\begin{array}{l}\text { Os serviços públicos não devem ser interrompidos, pois representam necessidades } \\
\text { prementes e inadiáveis da sociedade. }\end{array}$ \\
\hline Segurança Jurídica & $\begin{array}{l}\text { A Administração Pública deve respeitar a irretroatividade da lei e o direito } \\
\text { adquirido, salvo os casos previstos em lei. }\end{array}$ \\
\hline Precaução & A Administração Pública deve agir buscando se precaver de eventuais catástrofes. \\
\hline Razoabilidade & $\begin{array}{l}\text { A Administração Pública deve agir com bom senso, prudência, moderação e } \\
\text { tomando atitudes adequadas e coerentes. }\end{array}$ \\
\hline Proporcionalidade & $\begin{array}{l}\text { Os atos da Administração Pública devem ser adequados, evitando o excesso de } \\
\text { poder. }\end{array}$ \\
\hline
\end{tabular}

Fonte: Elaborado pelo autor com base em Carvalho Filho (2015). 
Não obstante apenas a eficiência ter sido citada como princípio da Administração Pública, a literatura, principalmente no que tange a gestão, também identifica a eficácia e a efetividade como princípios balizadores, como pode ser observado em estudos diversos, tais quais: Plano Diretor de Reforma do Aparelho do Estado - PDRAE (BRASIL, 1995); Modelo de Excelência em Gestão Pública MEGP (BRASIL, 2014); e Gestão por Resultados e Eficiência na Administração Pública: uma análise à luz da experiência de Minas Gerais (GOMES, 2009). Segundo o Guia Referencial para Medição de Desempenho e Manual para Construção de Indicadores (BRASIL, 2009) pode-se entender esses princípios como: (1) "Eficácia é a quantidade e qualidade de produtos e serviços entregues ao usuário"; (2) "Efetividade são os impactos gerados pelos produtos/serviços, processos e projetos".

\subsection{1. \\ O Modelo Gerencial de Administração Pública}

Ao longo da trajetória histórica da Administração Pública brasileira, três diferentes modelos marcantes referentes à organização pública das instituições brasileiras foram revelados. Esses modelos, embora se sucedam no tempo, não são abandonadas por completo, coexistindo como forma inerente do processo evolutivo (SILVA, PEREIRA e ALCÂNTARA, 2012). Corroborando essa visão, o PDRAE explicita as características dos modelos, conforme observado no Quadro 3.

No mundo desenvolvido, o modelo gerencial, também conhecido como New Public Management, tornou-se realidade, quando, por meio da descentralização, da mudança de estruturas organizacionais, da definição clara de objetivos para cada unidade da administração e da adoção de comportamentos e valores modernos pelo Estado, destacou-se com maior capacidade de promover o aumento da eficácia, efetividade e eficiência dos serviços sociais ofertados pelo setor público (BRASIL, 1995).

Peci, Pieranti e Rodrigues (2008) discorrem sobre a evolução de conceitos dentro do contexto da administração pública brasileira, pela Reforma do Aparelho de Estado (BRASIL, 1995). Nesse documento, segundo os autores, houve separação entre a administração e a política, maior autonomia no processo 
decisório, além da inclusão do conceito de cidadão-cliente e aumento da transparência na administração pública.

\section{Quadro 3 - Características das fases da Administração Pública}

\begin{tabular}{|c|c|c|}
\hline $\begin{array}{l}\text { Administração Pública } \\
\text { Patrimonialista }\end{array}$ & $\begin{array}{c}\text { Administração Pública } \\
\text { Burocrática }\end{array}$ & $\begin{array}{c}\text { Administração Pública } \\
\text { Gerencial }\end{array}$ \\
\hline $\begin{array}{l}\text { Aparelho do Estado como } \\
\text { extensão de poder do } \\
\text { soberano. }\end{array}$ & $\begin{array}{l}\text { Surge na metade do século } \\
\text { XIX, como forma de combater } \\
\text { a corrupção e o nepotismo. }\end{array}$ & $\begin{array}{l}\text { Surge na segunda metade do } \\
\text { século XX, como forma de } \\
\text { aumentar a eficiência do } \\
\text { estado, buscando tratar o } \\
\text { cidadão como cliente. }\end{array}$ \\
\hline $\begin{array}{l}\text { Os bens do governante são } \\
\text { confundidos com os bens } \\
\text { públicos. }\end{array}$ & $\begin{array}{l}\text { Utiliza princípios como } \\
\text { profissionalismo, } \\
\text { impessoalidade e hierarquia } \\
\text { funcional. }\end{array}$ & $\begin{array}{l}\text { Embora busque aumento de } \\
\text { eficiência, não rompe } \\
\text { inteiramente } \\
\text { administração } \\
\text { burocrática. A pública } \\
\text { diferença encontra-se na } \\
\text { mudança do controle por } \\
\text { processo para o controle por } \\
\text { resultados. }\end{array}$ \\
\hline \multirow[t]{2}{*}{$\begin{array}{l}\text { Corrupção e nepotismo } \\
\text { inerente a esse tipo de } \\
\text { administração. }\end{array}$} & $\begin{array}{l}\text { Parte-se de uma desconfiança } \\
\text { prévia nos administradores } \\
\text { públicos e nos cidadãos que a } \\
\text { eles dirigem demandas. }\end{array}$ & $\begin{array}{l}\text { A estratégia volta-se para a } \\
\text { definição precisa de objetivos, } \\
\text { garantia de autonomia do } \\
\text { gestor na administração dos } \\
\text { recursos e controle a posteriori } \\
\text { dos resultados. }\end{array}$ \\
\hline & $\begin{array}{l}\text { Buscando o controle máximo, o } \\
\text { Estado perde eficiência, sendo } \\
\text { incapaz de atender aos } \\
\text { cidadãos de maneira efetiva. }\end{array}$ & $\begin{array}{l}\text { Esse tipo de gestão inspira-se } \\
\text { na iniciativa privada, porém } \\
\text { não deve haver confusão } \\
\text { devido aos fins dos serviços } \\
\text { prestados. }\end{array}$ \\
\hline
\end{tabular}

Fonte: Elaborado pelo autor com base no Plano Diretor de Reforma do Aparelho do Estado (BRASIL, 1995).

\subsection{2.}

\section{Boas Práticas de Gestão em Órgãos e Entidades Públicas Brasileiras}

A partir do ponto de partida dado pelo PDRAE, baseado na administração pública gerencial, outros documentos oficiais foram gerados buscando tornar a 
administração pública brasileira mais eficiente, eficaz e efetiva. O mais recente deles é intitulado de Modelo de Excelência em Gestão Pública.

Esse modelo tem como premissa básica que a administração pública deve ser excelente, respeitando os princípios que a regem e os conceitos e linguagens que caracterizam a natureza pública das organizações, ou seja, que impactam sua gestão. O MEGP está baseado em onze fundamentos considerados vitais para a gestão de excelência contemporânea, sendo eles pensamento sistêmico, aprendizado organizacional, cultura de inovação, liderança e constância de propósitos, orientação por processos e informações, visão de futuro, geração de valor, comprometimento com as pessoas, foco no cidadão e na sociedade, desenvolvimento de parcerias e gestão participativa.

Ainda nesse documento, estão descritas as oito dimensões que fazem parte do MEGP. Essas dimensões, expostas na Figura 1, são divididas em quatro blocos, os quais representam o Ciclo PDCA.

Figura 1 - Sistema de Gestão Pública

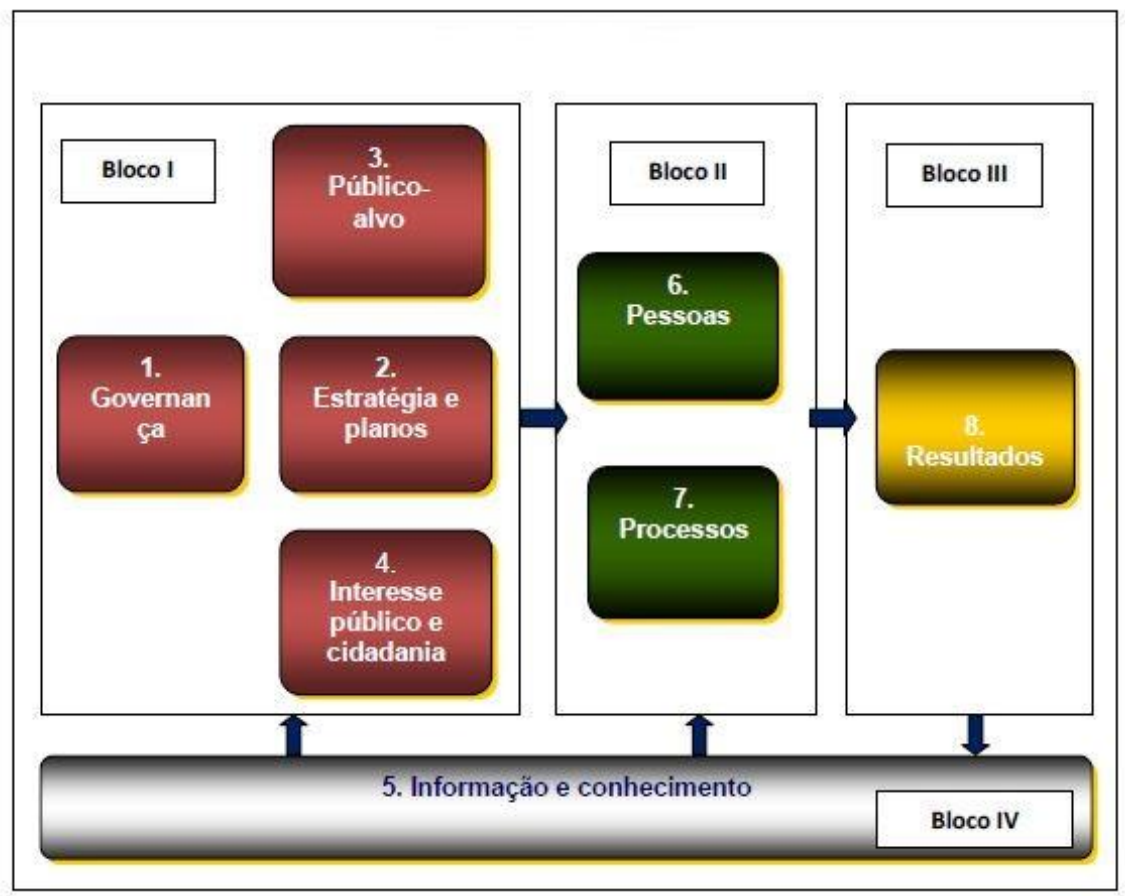

Fonte: Modelo de Excelência em Gestão Pública (BRASIL, 2014).

A forma de organização do documento é descrita a seguir:

O Bloco I é constituído pela etapa de Planejamento, em que são abrangidas as dimensões de Governança, Estratégia e Planos, Sociedade, Interesse Público e 
Cidadania. Essas partes possuem o objetivo de mover a organização conferindolhes direção.

- Governança - Diz respeito ao exercício de autoridade, controle, gerenciamento e poder do governo. Relaciona-se, também, com recursos de pessoal, tecnológicos, de infraestrutura, dentre outros de que os órgãos dispõem para formular, planejar e implantar as políticas públicas, assim como acompanhar, avaliar e fiscalizar a sua execução e resultados obtidos.

- Estratégia e Planos - Refere-se à formulação e implementação da estratégia, tendo como fundamento o exercício reflexivo sobre o futuro e a integração ao processo decisório.

- Público Alvo - Diz respeito às práticas gerenciais direcionadas ao relacionamento do órgão com os cidadãos, abrangendo questões como imagem institucional, conhecimento que a sociedade possui sobre o órgão e indução à participação social.

- Interesse Público e Cidadania - Refere-se à observância do interesse público e ao regime administrativo e o controle e participação social.

O Bloco II é constituído pela etapa de Execução, contemplando as dimensões de Pessoas e Processos. Essas partes são os responsáveis por transformar finalidades e objetivos em resultados.

- Pessoas - Refere-se à importância de padrões remuneratórios adequados, gestão por competência, gestão do desempenho e processos de capacitação e desenvolvimento continuados aos agentes públicos.

- Processos - Diz respeito à adequação dos processos finalísticos e de apoio à estratégia institucional, considerando os recursos disponíveis, os requisitos dos públicos alvos e as possibilidades jurídico-legais.

O Bloco III é constituído pela etapa de Controle, em que está contida a dimensão Resultado. Essa parte possui o objetivo de analisar a qualidade do sistema de gestão e do nível de desempenho institucional.

- Resultado - Diz respeito ao acompanhamento das ações efetuadas pelos gestores públicos, possibilitando correção nos rumos dos processos de 
trabalho e propiciando oportunidades de desenvolver estratégias de acompanhamento aos cidadãos.

O Bloco IV é constituído pela etapa de Ação, que abrange a dimensão Informação e Conhecimento. Essa dimensão dá à entidade a capacidade de corrigir, melhorar ou inovar suas práticas de gestão e, consequentemente, o desempenho.

- Informação e Conhecimento - Diz respeito à capacidade de gestão das informações e do conhecimento por parte do Estado aos usuários internos e externos da forma mais atualizada, precisa e segura possível.

Não obstante a dimensão Estratégia e Planos estar alocada no bloco de Planejamento, é simples constatar a presença do tema estratégia em todos os blocos descritos no MEGP. A preocupação recorrente nos estágios de formulação, implementação, avaliação e retroalimentação deixa claro, mesmo que de forma implícita, o objetivo do modelo de implementar um processo de gestão estratégica dentro das instituições públicas, como forma de aprimoramento do processo de gestão pública.

\section{2. \\ Gestão Estratégica}

Com o objetivo de contextualizar o conceito de gestão estratégica, é interessante elucidar, inicialmente, a concepção básica por trás dessa forma de gestão, a estratégia. $\mathrm{O}$ conceito de estratégia está fundamentado nos conceitos militares sobre como vencer os inimigos, tendo sido, após a Segunda Guerra Mundial, transposto e ampliado para o meio empresarial. Essa ampliação passou a considerar não somente a vitória sobre o inimigo como objetivo, mas também a concretização de uma situação futura desejada por parte da empresa, tendo em vista, por um lado, as oportunidades oferecidas pelos mercados e, por outro, os recursos à disposição da organização (FERNANDES e BERTON, 2012). A definição de estratégia, no contexto empresarial, é diversificada, embora palavraschaves possam ajudar na sintetização desse conceito, sendo elas competitividade, mudanças, desempenho, posicionamento, missão, objetivos, resultados, integração, adequação organizacional (CAMARGO e DIAS, 2013). Algumas definições de estratégia podem ser observadas no Quadro 4. 
Quadro 4 - Definições de estratégia

\section{Definição}

\section{Autor}

Procura deliberada por um plano de ação que irá desenvolver uma vantagem competitiva para um negócio.

Henderson (1989, p.3)

Conjunto de regras de tomada de decisão, visando à orientação do comportamento de uma organização. Abrange objetivos e metas, regras de desenvolvimento da relação entre

o ambiente externo e a empresa, regras para o Ansoff e McDonnel (1993, p.70) estabelecimento das relações e dos processos internos na organização e regras das atividades do dia-a-dia conduzidas pela empresa.

Conjunto dos grandes propósitos, dos objetivos, das metas, das políticas e dos planos para concretizar uma situação futura desejada, considerando as oportunidades oferecidas pelo Fernandes e Berton (2012, p. 4) ambiente e os recursos da organização.

Teoria da firma sobre como atingir altos níveis de desempenho nos mercados e nas indústrias nas quais opera.

Barney (2014, p.3)

Outro conceito anterior ao de gestão estratégica é o planejamento estratégico convencional. Desenvolvido na década de 1950, com o objetivo de solucionar a falta de sintonia entre a oferta de produtos pelas corporações e o mercado que se destinava a consumi-los, esse conceito pode ser compreendido como a análise racional das oportunidades e ameaças proporcionadas pelo ambiente, dos pontos fortes e fracos existentes dentro das organizações e da escolha de uma forma de compatibilização (estratégia) entre os dois opostos satisfazendo da melhor forma possível os objetivos das organizações. Uma vez escolhida a estratégia ideal, as empresas deveriam implementá-la (ANSOFF, DECLERCK e HAYES, 1990).

Apesar do objetivo inicial, devido às mudanças rápidas e radicais ocorridas no ambiente, esse tipo de planejamento estratégico mostrou-se ineficaz pela sua abordagem essencialmente cartesiana, sem considerar que as mudanças externas e internas influenciam de forma constante o processo. Ademais, as etapas de implementação e avaliação das estratégias pré-estabelecidas são consideradas tarefas secundárias no processo (ANSOFF, DECLERCK e HAYES, 1990).

Segundo Ansoff e Mcdonnel (1993), visando o aprimorando desse processo, a gestão estratégica foi desenvolvida e agregou três elementos significativos ao planejamento estratégico convencional. Esses elementos são explicitados abaixo: 
1. Planejamento de potencialidades;

a. Verificação das potencialidades necessárias por parte da organização para a execução da estratégia.

2. Administração das questões estratégicas;

a. Foco no monitoramento e avaliação contínua das tendências ambientais nas áreas empresariais.

3. Gestão sistemática da resistência à mudança.

a. Preparação da organização para as mudanças que ocorrerão decorrentes das escolhas estratégicas efetuadas.

Não obstante a diferenciação entre planejamento estratégico e gestão estratégica ser clara na opinião de Ansoff, Declerck e Hayes (1990) e Ansoff e Mcdonnel (1993), o mesmo não pode ser dito sobre a literatura concernente a esses temas em geral. Melo (1997) ressalta a evolução que o conceito de planejamento estratégico obteve desde a década de 1950, transformando-se em planejamento adaptativo e envolvendo elementos relacionados à aprendizagem organizacional e a adoção da metodologia de pesquisa-ação; adaptação e participação ativa; domínio interorganizacional e transformação do sistema; flexibilidade e avaliação contínua das ações implementadas, dentre outros que demonstram a adaptação do conceito de planejamento estratégico às mudanças exigidas pelo mercado contemporâneo de maior agilidade, inovação e conhecimento do negócio e dos clientes. Corroborando essa visão, Fernandes e Berton (2012) afirmam não existir consenso quanto à diferenciação entre planejamento estratégico e gestão estratégica, tendo alguns autores considerado como termos idênticos e outros procurado estabelecer diferenças sutis.

Assim como as obras de Bryson (2010) e Fernandes e Berton (2012), esse estudo entende a gestão estratégica como um processo mais amplo que engloba o planejamento, a execução e o monitoramento, enquanto o planejamento estratégico, nessa concepção, limita-se, exclusivamente, ao ato de planejar.

Nos dias atuais, o processo de gestão estratégica é uma das áreas relacionadas à gestão com maior relevância e destaque. Essa importância está contida no fato de que esse processo é constituído por uma série de ações gerenciais que possibilitam aos gestores de uma organização mantê-la integrada ao seu ambiente 
e no caminho correto para seu desenvolvimento, garantindo-lhes o atingimento de seus objetivos e de sua missão (CAMARGOS e DIAS, 2003).

A definição do processo de gestão estratégica, tal qual do conceito estratégia, também é diversificada. A partir da análise da Tabela 5 e da literatura concernente àquele tema, porém, pode-se encontrar similaridades que possibilitam entender a gestão estratégica como um processo sistêmico e contínuo de formulação, implementação e avaliação das ações estratégicas visando o alcance dos objetivos organizacionais. Algumas definições desse processo podem ser observadas no Quadro 5.

\section{Quadro 5 - Definições de gestão estratégica}

\begin{tabular}{|c|c|}
\hline Definição & Autor \\
\hline $\begin{array}{l}\text { Abordagem sistemática à gestão de mudanças } \\
\text { estratégicas, compreendendo o posicionamento da } \\
\text { empresa através da estratégia e do planejamento de } \\
\text { potencialidades, resposta estratégica em tempo real } \\
\text { através da administração de questões e a gestão } \\
\text { sistemática da resistência durante a implantação da } \\
\text { estratégia. }\end{array}$ & Ansoff e Mcdonnel (1993, p. 16) \\
\hline $\begin{array}{l}\text { Uma série de passos em que a alta administração deve } \\
\text { realizar as tarefas a seguir: (1) analisar oportunidades e } \\
\text { ameaças ou limitações que existem no ambiente externo; } \\
\text { (2) analisar os pontos fortes e fracos do seu ambiente } \\
\text { interno; (3) estabelecer a missão organizacional e os } \\
\text { objetivos gerais; (4) formular estratégias que permitam à } \\
\text { organização combinar os pontos fortes e fracos da } \\
\text { organização com as oportunidades e ameaças do } \\
\text { ambiente; (5) implementar as estratégias; (6) realizar } \\
\text { atividades de controle estratégico para assegurar que os } \\
\text { objetivos gerais da organização sejam atingidos. Os } \\
\text { passos, embora mostrados sequencialmente, são } \\
\text { altamente inter-relacionados. }\end{array}$ & Wright, Kroll e Parnell (2000, p. 24). \\
\hline $\begin{array}{l}\text { É o conjunto de compromissos, decisões e ações } \\
\text { necessários para que a empresa obtenha vantagem } \\
\text { competitiva e retornos acima da média. }\end{array}$ & Hitt, Ireland e Hoskisson $(2011$, p. 6) \\
\hline $\begin{array}{l}\text { Processo de análises e escolhas sequenciais que } \\
\text { aumentam a possibilidade da firma escolher uma } \\
\text { estratégia que melhore seu desempenho. }\end{array}$ & Barney $(2014, p .5)$ \\
\hline
\end{tabular}


Tais quais as empresas privadas, as organizações públicas vêm enfrentando um grande nível de incerteza e interconectividade entre seus produtos e serviços. Por essa razão, as formas de gestão utilizadas no passado não mais se adéquam as necessidades dessas organizações. Assim, o processo de gestão estratégica oferece uma solução adequada e viável para lidar com esses imperativos ambientais. Para Bryson (2011), as organizações públicas, conforme o contexto acima descrito, devem:

1. Pensar e aprender estrategicamente;

2. Traduzir os insights estratégicos em estratégias efetivas;

3. Fornecer os recursos necessários para que as estratégias definidas ocorram de maneira adequada;

4. Formar coalizões fortes e amplas para protegê-las durante a implementação;

5. Construir as capacidades necessárias para implementar, aprender e mudar estrategicamente, caso necessário.

\section{3.}

\section{Avaliação de Maturidade em Gestão Estratégica}

Conforme Lockamy e McCormark (2004), o conceito de maturidade pressupõe a existência de diferentes estágios de desenvolvimento de um dado processo. Nesses estágios, os processos são avaliados pela forma que são definidos, gerenciados, mensurados e controlados. Siqueira (2005) expõe que organizações com processos maduros atingem seus objetivos de qualidade, prazos e custos com consistência e eficiência.

Os modelos de maturidade são definidos por Santos et al. (2010) como meios de comparação e avaliação de processos na busca pela melhoria necessária ao acréscimo da capacidade e competência da organização. Gabryelczyk (2016) acrescenta que os modelos de maturidade são usados como forma de mensuração de performance e de maturidade seja em processos, em áreas funcionais individuais ou na organização como um todo. Esses modelos, segundo Siqueira (2005), são referenciais usados para: (1) analisar a capacidade dos processos na realização de seus objetivos; (2) identificar oportunidades de melhoria nos 
quesitos de custos, qualidade e produtividade; (3) formular e avaliar as ações de melhoria contínua dos processos organizacionais.

O conceito de maturidade, tal qual as definições concernentes aos modelos de maturidade, foram delimitados no âmbito de processos. Não obstante, entendese que as informações acima seja extensíveis, em sua totalidade, ao estudo de projetos.

Os estudos sobre a questão da avaliação de maturidade em projetos e em processos são numerosos na literatura, como se pode observar pelos estudos de Grant e Pennypacker (2006), Rad e Levin (2006), Hammer (2007), Kundler (2012), Serek (2013), Cholez e Girard (2013) e Souza e Gomes (2015). Nesses tipos de trabalho, o setor que vem ganhando maior relevância é o TIC, em que aparecem estudos como os de Sarfaraz, Sauser e Bauer (2012), Kyriakidou, Michalakelis e Sphicopoulos (2013) e Redecker e Johannessen (2013).

Existem ainda estudos que buscam a avaliação da maturidade da gestão organizacional como um todo. Na administração pública, merece destaque a Autoavaliação da Gestão Pública, desenvolvida no âmbito do Programa Nacional de Gestão Pública e Desburocratização - GESPÚBLICA, cuja função é medir e avaliar a evolução da gestão pública em determinada instituição pública. Tal documento se baseia no MEGP como forma de estruturação do modelo e do questionário de mensuração, porém como citado anteriormente tem como foco a gestão de forma completa, comtemplando apenas uma dimensão referente a estratégias e planos.

No que diz respeito ao foco deste trabalho, a avaliação de maturidade em gestão estratégica, foram encontrados apenas dois artigos que tratam do tema. No primeiro deles, é abordado o Modelo de Maturidade em Gestão Estratégica (SMMMTM - Strategic Management Maturity Model $\left.{ }^{\mathrm{TM}}, 2010\right)$. Desenvolvido pelo Balanced Scorecard Institute - BSI, por seu Presidente e Chief Executive Officer CEO, Howard Rohm, esse modelo de avaliação em gestão estratégica é dividido em oito dimensões, pelas quais se busca definir o grau de maturidade da organização no processo de gerenciamento estratégico. O segundo artigo, escrito por Corneliu e Diana (2013), trata a avaliação da qualidade do processo de gestão estratégica, utilizando como base do estudo o $S M M M^{\mathrm{TM}}$. 


\subsection{1. \\ Strategic Management Maturity Model ${ }^{\mathrm{TM}}$}

O $S M M M^{\mathrm{TM}}$ tem como objetivo proporcionar aos gestores uma avaliação rápida sobre o grau de maturidade de sua organização no processo de gestão estratégica, possibilitando o monitoramento do progresso nesse processo e permitindo o benchmarking entre organizações e departamentos internos. Tal monitoramento e benchmarking permite aos gestores identificar problemas e posteriormente desenvolver um conjunto de ações para melhoria do desempenho organizacional no âmbito da gestão estratégica. A escolha do $S M M M^{\mathrm{TM}}$ como base para a construção desta pesquisa deu-se (1) pela completude que esse modelo proporciona, uma vez que abrange oito dimensões da gestão estratégica, apontando para cada uma delas um conjunto de recomendações com vistas ao alcance do mais alto nível de maturidade; (2) pela simplicidade e facilidade de entendimento, podendo ser aplicado, em sua maioria, em funcionários de diversos níveis organizacionais; (3) pela base informacional sob o qual foi construído (mais de 200 consultorias e treinamentos, em organizações públicas e privadas, ao longo de 15 anos); e (4) por tratar-se de um modelo genérico, aplicável tanto em organizações públicas quanto privadas.

Conforme exposto por Howard Rohm, via e-mail, transcrito no Anexo B, o $S M M M^{\mathrm{TM}}$ teve como base o Modelo de Maturidade de Capacidade (CMM Capability Maturity Model) desenvolvido, na década de 1980, por um estudo financiado pelo Departamento de Defesa dos Estados Unidos com o objetivo de melhorar os processos de desenvolvimento de software que vinham sendo usados por contratados do governo. Assim, baseado no CMM, o foco de avaliação foi trocado para a análise de efetividade da gestão estratégica, utilizando níveis e dimensões de maturidade fundamentados em mais de 200 consultorias e treinamentos realizados - em organizações como Blue Man Group, Cisco, Departamento de Comércio dos Estados Unidos, Força Aérea dos Estados Unidos, Fundo das Nações Unidas para a Infância - UNICEF, Mary Kay etc. em 40 países ao longo de mais de 15 anos de atividade. Ainda segundo Rohm, o modelo foi refinado para ajudar as organizações a criarem linhas de base que possibilitem acompanhar o progresso do seu gerenciamento de desempenho à medida que 
sejam implementadas várias iniciativas de mudança de desempenho em suas organizações.

O $S M M M^{\mathrm{TM}}$ divide-se em oito dimensões, consideradas como partes integrantes do processo de gestão estratégica, tendo cada uma delas cinco níveis possíveis de maturidade. As dimensões e os níveis de maturidade estão apresentados na Figura 2.

Figura 2 - Dimensões e níveis de maturidade em gestão estratégica

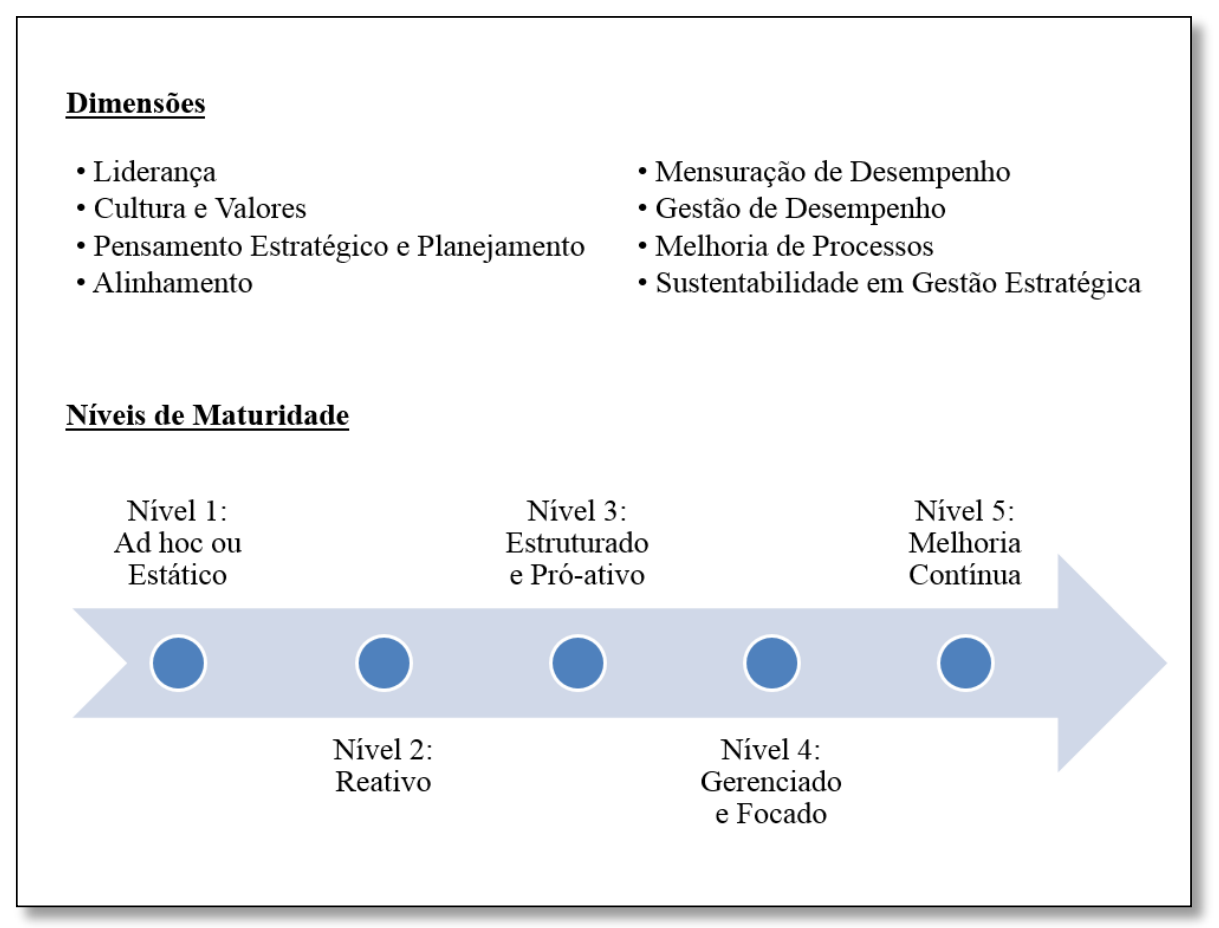

Fonte: Elaborado pelo autor com base no Strategic Management Maturity Model ${ }^{\mathrm{TM}}$, Balanced Scorecard Institute (2010).

Os níveis de maturidade, no âmbito do modelo, podem ser divididos em dois grupos: (1) níveis de maturidade do processo de gestão estratégica e (2) níveis de maturidade dentro de cada dimensão. As características do primeiro grupo estão descritas no Quadro 6, e as características do segundo são abordadas nos subtópicos correspondentes.

A coleta de dados para avaliação do nível de maturidade em gestão estratégica da entidade é realizada com base na resposta ao questionário disponibilizado pelo modelo, no qual em cada dimensão apenas um nível de maturidade é assinalado. Esse questionário é apresentado no Anexo A deste estudo. 
Para cálculo da pontuação final visando à verificação do nível de maturidade em gestão estratégica, é importante salientar que cada resposta, por dimensão, vale de 1 a 5 pontos, dependendo da marcação do entrevistado. Após todas as marcações efetuadas dentro das dimensões, o valor total é somado e o nível de maturidade em gestão estratégica é verificado segundo as seguintes regras: de 8 a 11 pontos, nível 1; de 12 a 19 pontos, nível 2; de 20 a 27 pontos, nível 3; de 28 a 35 pontos, nível 4; de 35 a 40 pontos, nível 5.

\section{Quadro 6 - Níveis de maturidade em gestão estratégica}

\begin{tabular}{|c|l|}
\hline \multicolumn{1}{|c|}{ Nível de Maturidade } & \multicolumn{1}{|c|}{ Descrição } \\
\hline Nível 1: Ad Hoc e Estático & $\begin{array}{l}\text { As organizações deste nível não realizam a gestão } \\
\text { estratégica no sentido formal. O planejamento tende a } \\
\text { focar somente ações táticas e operacionais de maneira } \\
\text { ad hoc e descontrolada, sendo realizado, normalmente, } \\
\text { pela alta liderança de maneira isolada. Os líderes não } \\
\text { se concentram em estratégias de longo prazo, focando } \\
\text { a maioria do seu tempo em atividades operacionais e } \\
\text { problemas de curtíssimo prazo. }\end{array}$ \\
\hline Nível 2: Reativo & $\begin{array}{l}\text { As organizações deste nível aplicam alguns elementos } \\
\text { efetivos de gestão estratégica, porém, de forma } \\
\text { inconsistente, e com poucos resultados. O } \\
\text { planejamento não é rigoroso, ocorrendo de forma } \\
\text { reativa ou para agradar algum líder temporariamente. } \\
\text { Essas organizações podem medir o desempenho e usá- } \\
\text { lo, talvez, para punir seus colaboradores com baixa } \\
\text { performance. Essa medição de desempenho, } \\
\text { normalmente, é realizada por indivíduos e busca } \\
\text { atender a uma atividade política rotineira, não sendo } \\
\text { levada à sério. }\end{array}$ \\
\hline
\end{tabular}


Quadro 6 - Níveis de maturidade em gestão estratégica (continuação)

\begin{tabular}{|c|c|}
\hline Nível de Maturidade & Descrição \\
\hline Nível 4: Gerenciado e Focado & $\begin{array}{l}\text { As organizações deste nível são guiadas pela } \\
\text { estratégia. Os padrões e métodos organizacionais são } \\
\text { amplamente utilizados para implementar a gestão } \\
\text { estratégica. Os líderes envolvem formalmente os } \\
\text { colaboradores no processo e a mensuração e a cultura } \\
\text { de responsabilidade auxiliam no sucesso estratégico } \\
\text { da organização. }\end{array}$ \\
\hline Nível 5: Melhoria Contínua & $\begin{array}{l}\text { As organizações desse nível têm o processo de gestão } \\
\text { estratégica profundamente enraizado nas suas culturas } \\
\text { e em estado de melhoria contínua. Isso significa que, à } \\
\text { medida que o desempenho é avaliado, as organizações } \\
\text { buscam, primeiramente, analisar como foi o } \\
\text { desempenho em comparação com os objetivos } \\
\text { estratégicos e, em segundo lugar, o quão efetivo o } \\
\text { planejamento estratégico e a gestão de processos são, } \\
\text { adaptando-os como necessário. A excelência em } \\
\text { gestão estratégica guia as organizações em direção à } \\
\text { vantagem competitiva e ao desempenho superior. }\end{array}$ \\
\hline
\end{tabular}

Fonte: Elaborado pelo autor com base no Strategic Management Maturity Model ${ }^{\mathrm{TM}}$ (Balanced Scorecard Institute, 2010).

As dimensões abrangidas pelo modelo serão discutidas nos itens seguintes, conforme disposto no $S M M M^{\mathrm{TM}}$ e na literatura sobre a gestão estratégica.

\subsubsection{1. Liderança}

Wright, Kroll e Parnell (2000) conceituam liderança, na ótica estratégica, como o estabelecimento de orientação para a empresa, com o desenvolvimento e comunicação de uma visão de futuro, buscando motivar e incentivar os funcionários a se moverem nessa direção. Corroborando essa ideia, Hitt, Ireland e Hoskisson (2011) destacam que o processo de gestão estratégica só pode ser utilizado com sucesso caso os líderes estratégicos da organização estejam envolvidos. Segundo os autores, esse comprometimento da liderança ocorre de maneiras diversas no processo, focando em: (1) modelar a formulação da visão e 
da missão; (2) influenciar nas ações estratégicas; (3) gerar retornos acima da média com a competitividade estratégica.

Rodrigues e Santos (2001) expõem a importância do empowerment para a gestão estratégica e para o sucesso empresarial contemporâneo. Segundo eles, esse conceito pode ser definido como um processo de trabalho cujo objetivo se concentra na delegação de poder, participação e autonomia dos funcionários na administração das empresas. Ghosh (2013) aponta, ainda, a necessidade de utilização do empowerment como uma ferramenta estratégica para atingimento dos objetivos organizacionais.

Em consonância com o exposto acima, o $S M M M^{\mathrm{TM}}$ entende que uma gestão estratégica eficaz começa com a liderança. Os líderes questionam premissas e observam os problemas por uma nova ótica, além de criarem e articularem a visão de futuro da organização. No contexto da gestão estratégica, as boas práticas apontadas pelo modelo nessa dimensão estão identificadas no Quadro 7.

\section{Quadro 7 - Boas práticas em Liderança}

Líderes definem uma visão de futuro clara e consistente sobre a organização.

Líderes são pró-ativos na preparação da organização para o futuro.

Líderes são acessíveis e engajados para garantir o entendimento, por parte dos funcionários, de uma

visão comum e para que eles consigam traduzi-la em termos relevantes para a execução dos

trabalhos.

Líderes são consistentes entre o que dizem e o que fazem no que diz respeito aos valores, à ética e às políticas da organização.

Líderes não microgerenciam, preferem confiar e encorajar os funcionários a contribuir com ideias e estimular o crescimento em suas carreiras.

Líderes interagem e trabalham lado a lado com os funcionários, estimulando o trabalho em equipe.

Fonte: Elaborado pelo autor com base no Strategic Management Maturity Model ${ }^{\mathrm{TM}}$ (Balanced Scorecard Institute, 2010).

Os níveis de maturidade alcançados nesta dimensão, conforme o $S M M M^{\mathrm{TM}}$, são:

- Nível 1: Ad Hoc e Estático

○ Os líderes são ditatoriais, preocupando-se exclusivamente com as atividades de comando e controle. 
- Nível 2: Reativo

○ Os líderes são ditatoriais, mas preocupam-se esporadicamente em darfeedbacks.

- Nível 3: Estruturado e Pró-ativo

- Os líderes engajam-se apenas com seus reportantes diretos, mas modelam os valores e comportamentos desejados.

- Nível 4: Gerenciado e Focado

- Os líderes empoderam os funcionários, buscando seus engajamentos contínuos.

- Nível 5: Melhoria Contínua

- Os líderes e os funcionários estão completamente engajados, utilizando o diálogo contínuo baseado em uma cultura de equipe.

\subsubsection{2.}

\section{Cultura e Valores}

A cultura organizacional pode ser definida, segundo Fleury (1987, p. 10), como "um conjunto de valores e crenças compartilhados pelos membros de uma organização". Complementando essa visão, Schein (2004) entende que a cultura organizacional pode ser analisada em três diferentes níveis, de acordo com o grau em que o fenômeno cultural é visível para o observador. Esses níveis são subdivididos da seguinte forma: (1) artefatos, que se referem às estruturas e aos processos organizacionais visíveis, como cerimônias, arquitetura física do ambiente, formas de vestimenta etc.; (2) valores e crenças explícitas, características vistas como importantes pelos membros da organização, devendo balizar o comportamento praticado, na maioria das vezes, representando, porém, idealizações ou racionalizações, como estratégias, objetivos e filosofias; (3) suposições básicas, que dizem respeito à internalização das suposições adotadas na organização, como pensamentos, sentimentos e crenças implícitas, representando a real motivação para o comportamento dos indivíduos.

A cultura organizacional, e consequentemente os valores compartilhados, no que diz respeito à gestão estratégica, conforme Estrada e Almeida (2007), é decisiva para a elaboração e implementação de projetos planejados nas organizações, sendo indispensável sua análise prévia e posterior adequação à nova 
estrutura estratégica da instituição. Bethlem (2002) corrobora essa visão entendendo a cultura organizacional como fator vital de sucesso. Segundo a autora, isso deve-se à necessidade do estabelecimento e da internalização de valores comuns e congruentes com as estratégias organizacionais definidas, sem os quais o processo de gestão estratégica se tornaria inviável ou ocorreria da forma inadequada.

Para que a organização tenha sucesso no processo de gestão estratégica, conforme exposto acima, ela deve adequar sua cultura organizacional às estratégias organizacionais definidas. Tal adequação, porém, não ocorre de forma automática e pacífica, sofrendo muitas vezes resistências dentro da própria organização (ROTHARMEL, 2015). Com vistas a realizar essa harmonização, o conceito de gestão de mudança, definido por Hayes (2002) como um processo de modificação e transformação organizacional que visa manter e aprimorar a eficácia institucional, deve ser implementado. Conforme Jones, Aguirre e Calderone (2004), esse conceito possui princípios a serem considerados para sua correta aplicação, sendo eles: (1) envolver o lado humano sistematicamente; (2) iniciar a conscientização com as lideranças; (3) envolver todos os níveis organizacionais; (4) explicitar a mudança formalmente, com a definição da visão, a produção de estudos de caso, reuniões de conscientização etc.; (5) criar um sentimento de propriedade nos líderes do processo de mudança; (6) comunicar a mensagem de forma clara para que todos tenham o mesmo entendimento, evitando ruídos; (7) avaliar previamente a cultura organizacional; (8) guiar a cultura organizacional desejada explicitamente; (9) preparar-se para problemas inesperados; (10) falar diretamente com o indivíduo.

Esta dimensão, segundo o $S M M M^{\mathrm{TM}}$, refere-se à cultura e aos valores praticados dentro da organização que guiam os líderes e os colaboradores para um entendimento compartilhado sobre os valores declarados. Ainda, segundo o modelo, a maioria das organizações possui uma lista com valores virtuosos, porém o que diferencia a maturidade é o nível de comunicação, entendimento e aplicação dos valores previamente estabelecidos. As evidências que pressupõem maturidade na cultura e nos valores organizacionais são expostas no Quadro 8. 
Quadro 8 - Boas práticas em Cultura e Valores

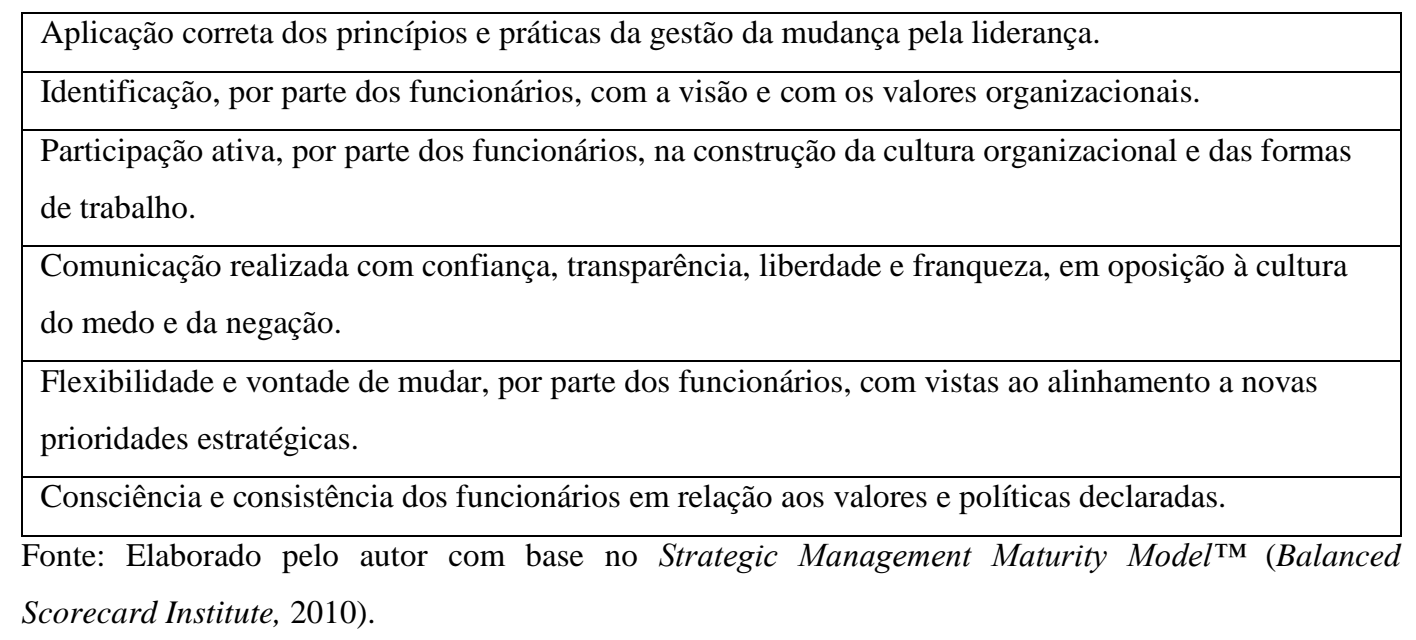

Os diferentes níveis de maturidade dentro desta dimensão, conforme constante no $S M M M^{\mathrm{TM}}$, são:

- Nível 1: Ad Hoc e Estático

○ A visão e os valores são indefinidos ou não são compartilhados.

- Nível 2: Reativo

○ A visão e os valores são publicados, mas não são vividos.

- Nível 3: Estruturado e Pró-ativo

- A visão e os valores são comunicados e entendidos.

- Nível 4: Gerenciado e Focado

○ A visão e os valores são desenvolvidos de forma colaborativa.

- Nível 5: Melhoria Contínua

- A visão e os valores são completamente integrados à cultura organizacional.

\subsubsection{3.}

\section{Pensamento Estratégico e Planejamento}

Conforme Melo (1987), no que concerne ao processo de planejamento, no âmbito estratégico, pode-se observar a evolução das visões dominantes segundo um processo dialético ao longo da segunda metade do século XX. Melo (1997) entende o chamado Planejamento Racional Compreensivo como a proposta inicial com foco na centralização, no sequenciamento e na sistemática do processo de planejamento. Corroborando essa visão e nomeando-a de perspectiva clássica, Volberda (2004) acrescenta que o esse tipo de concepção de planejamento 
envolve o planejamento deliberado (formal), iniciado pelos líderes de cúpula (hierárquico) com foco no desenvolvimento de uma estratégica corporativa ambiciosa e coesa (consistente). O autor afirma, ainda, com base nos estudos de Mitzberg e Waters (1985) e Fredrickson (1984), que essa visão de planejamento ignora a possibilidade das estratégias, as vezes, emergirem de iniciativas de gestores das linhas de frente, da base para o topo, além de se mostrar insuficiente para a atuação em ambientes turbulentos, conduzindo a organização à rigidez, restringindo seu potencial de inovação.

Contrapondo essa visão, encontra-se o incrementalismo disjunto exposto por Lindblom (1959). Essa metodologia enfatiza a busca por melhoramentos marginais, implementados de forma fragmentada, com o objetivo de enfrentar problemas desconexos, considerando assim, o planejamento como artificial. Nessa ótica, o planejamento racional compreensivo é considerado inadequado à realidade, devido, por exemplo, as limitações inerentes à capacidade humana de solucionar problemas (MELO, 1987).

A síntese dessas visões, segundo Melo (1997), deu-se no planejamento adaptativo. Esse tipo de planejamento caracteriza-se por enfatizar o nível normativo e por buscar maneiras inovadoras de produzir mudanças no sistema, devido ao seu alto grau de flexibilidade. Trist (1976) caracteriza o planejamento adaptativo como um processo contínuo de aprendizado, que demanda a participação e o envolvimento de todos os integrantes da organização. Melo (1997) ressalta, ainda, que o planejamento adaptativo é o mais apropriado para tempos de incerteza, complexidade e interdependência, possuindo características únicas, como:

- Estabelecimento de direções comuns, através da extensão do processo de planejamento ao nível normativo;

- Foco no domínio interorganizacional, com o objetivo de entender como essas inter-relações se comportam;

- Visualização do ambiente como passível de mudança, devendo a organização adotar uma postura pró-ativa para transformá-lo em um cenário mais favorável para sua atuação;

- Participação ativa dos membros da organização, buscando um sentimento de responsabilidade sobre o atingimento dos objetivos planejados; 
- Apreciação constante dos objetivos formulados e avaliação das ações implementadas possibilitando a redefinição de rumos;

- Adoção da metodologia de pesquisa-ação, visando o aprendizado por meio da reflexão sobre as ações realizadas;

- Busca de transformação radical do sistema, ocorrendo por meio de inovações, através de processos integrados e coordenados.

Para responder efetivamente ao ambiente e até mudá-lo, Bryson (2010) ressalta a importância da análise dos contextos externo e interno em que as organizações estão inseridas. Para o autor, as organizações atuais vivem em um contexto complexo, dinâmico e interconectado devendo buscar informações que possibilitem criar ideias de intervenções estratégicas que formem e guiem as decisões e ações organizacionais.

Um dos sustentáculos para o planejamento estratégico, e por conseguinte da gestão estratégica, segundo Sertek, Guindani e Martins (2007), é o pensamento estratégico. Segundo os autores, o pensamento estratégico foca a análise global (holística) dos cenários e dos problemas, visando realizar uma avaliação global de recursos e resultados.

No âmbito do planejamento estratégico, Bryson (2010) ressalta, ainda, dentre outros fatores, a importância de classificar adequadamente os assuntos estratégicos e operacionais, mensurando o quão estratégicos e operacionais esses assuntos são; a importância da utilização de vocabulário e formato adequados, possibilitando a todos os integrantes da organização o entendimento das ações referentes à gestão estratégica; a necessidade de alinhamento entre os objetivos do planejamento estratégico e o orçamento para que a implementação das estratégias ocorra de forma adequada; a relevância da construção de cenários de modo a promover o aprendizado por parte da equipe de planejamento, sensibilizando-a para futuros improváveis e desenvolvendo estratégias alternativas para lidar com a maioria das eventualidades.

O $\mathrm{SMMM}^{\mathrm{TM}}$ retrata o desenvolvimento da estratégia como um processo complexo e desafiador, que envolve o pensamento estratégico na busca de opções que ofereçam um melhor desempenho para a organização. No que concerne ao pensamento estratégico e ao planejamento, segundo o Modelo, as boas práticas são identificadas no Quadro 9. 
Quadro 9 - Boas práticas em Pensamento Estratégico e Planejamento

\begin{tabular}{|c|}
\hline $\begin{array}{l}\text { A organização deve possuir a habilidade de usar definições consistentes em termos de planejamento e entender } \\
\text { suas diferenças. }\end{array}$ \\
\hline A diferença entre planejamento de projetos e planejamento estratégico necessita ser entendida pela organização. \\
\hline $\begin{array}{l}\text { A organização deve ser capaz de discutir e descrever os itens em planos com a 'dimensão estratégica' } \\
\text { apropriada. }\end{array}$ \\
\hline A organização precisa ter consciência dos efeitos dinâmicos do sistema. \\
\hline A organização deve ser aberta a novas ideias e encorajar a criatividade e a inovação. \\
\hline O processo de planejamento necessita ser aberto para uma equipe de funcionários de vários níveis e funções. \\
\hline A organização precisa considerar estratégias e cenários alternativos. \\
\hline Deve existir ligação entre o planejamento estratégico e o orçamento. \\
\hline A organização necessita possuir a capacidade de escrever e falar com clareza e simplicida \\
\hline Fonte: Elaborado pelo autor com base no $S t$ \\
\hline
\end{tabular}

Os níveis de maturidade presentes nesta dimensão, conforme exposto pelo $S M M M^{\mathrm{TM}}$, são:

- Nível 1: Ad Hoc e Estático

○ Não existe planejamento estratégico na instituição e nenhum objetivo é definido.

- Nível 2: Reativo

○ O planejamento estratégico é responsabilidade de uma pequena equipe e ordenado à toda organização.

- Nível 3: Estruturado e Pró-ativo

- Um processo de planejamento estruturado e aberto envolve diversos funcionários dentro da organização de tempos em tempos.

- Nível 4: Gerenciado e Focado

- Planos são desenvolvidos e revisados diariamente por uma equipe treinada e multidisciplinar.

- Nível 5: Melhoria Contínua

- Estratégia guia as decisões organizacionais críticas e um processo de planejamento é sustentado. 


\subsubsection{4. \\ Alinhamento}

No âmbito da estratégia, conforme Prieto, Carvalho e Fischmann (2009), o conceito de alinhamento está presente tanto na formulação, quanto na implementação. No que concerne à formulação, o conceito está diretamente ligado ao ajuste da estratégia ao ambiente competitivo. Já no que diz respeito à implementação, é solicitada a integração entre vários elementos organizacionais, com ênfase na estrutura organizacional, pessoas, sistema de informações, métricas e formas de recompensas com o objetivo de alinhar as diversas características organizacionais com a estratégia. Corroborando com essa ideia, Osland (2004) entende que as diversas características organizacionais devem ser alinhadas de forma concomitante para que a estratégia seja implementada de maneira efetiva, uma vez que essas características são interdependentes sendo uma adaptação parcial insuficiente para a implementação estratégica bem sucedida.

No $S M M M^{\mathrm{TM}}$, entende-se alinhamento como o grau de comprometimento das pessoas e dos recursos com a estratégia organizacional. Por essa perspectiva, diversos fatores da organização devem ser alinhados, como: visão, valores, missão, planos estratégicos, orçamentos, políticas, funções, estrutura organizacional etc. Dessa forma, o $S M M M^{\mathrm{TM}}$ aborda, nesta dimensão, o alinhamento sobre a ótica da implementação, sendo o alinhamento na perspectiva da formulação abordado na dimensão denominada "Pensamento Estratégico e Planejamento". As boas práticas no que tange ao alinhamento, conforme o modelo, estão apresentadas no Quadro 10.

\section{Quadro 10 - Boas práticas no Alinhamento}

\begin{tabular}{l}
\hline Os funcionários de todos os níveis devem ser motivados por uma visão comum e pela estratégia. \\
\hline Os funcionários necessitam entender que sua função é dar suporte à estratégia. \\
\hline Os funcionários devem se auto-motivar, não atuando somente pela obediência as regras. \\
Fonte: Elaborado pelo autor com base no Strategic Management Maturity Model \\
Scorecard (Balanced \\
\end{tabular}

Os diferentes níveis de maturidade dentro desta dimensão, conforme constante no $S M M M^{\mathrm{TM}}$, são: 
- Nível 1: Ad Hoc e Estático

- O trabalho é estreitamente baseado na estrutura organizacional, com pequenas contribuições dos consumidores.

- Nível 2: Reativo

- As necessidades dos consumidores e o feedback começam a influenciar nas decisões, tornando-as mais alinhadas.

- Nível 3: Estruturado e Pró-ativo

- Os funcionários conhecem seus consumidores e alinham as estratégias a suas necessidades.

- Nível 4: Gerenciado e Focado

○ Visão, necessidades dos consumidores, estratégia e sistemas de premiação e reconhecimento dos funcionários estão alinhados.

- Nível 5: Melhoria Contínua

- Todas as estruturas e sistemas são alinhados com a estratégia. Além disso, o alinhamento organizacional é continuamente melhorado.

\subsubsection{5. \\ Mensuração de Desempenho}

Conforme o Manual de Orientação para a Gestão do Desempenho (BRASIL, 2013), a mensuração de desempenho deve ser realizada com o intuito de assegurar os objetivos organizacionais, de equipes e individuais, devendo essa mensuração ocorrer por meio de indicadores. Ferreira, Cassiolato e Gonzalez (2009) definem um indicador como:

\footnotetext{
uma medida, de ordem qualitativa ou quantitativa, dotada de significado particular e utilizada para organizar e captar as informações relevantes dos elementos que compõem o objeto da observação. É um recurso metodológico que informa empiricamente sobre a evolução do aspecto observado.
}

No âmbito de estudo dos indicadores, diversas classificações quanto à tipologia são possíveis. Conforme Lacombe e Albuquerque (2008), os indicadores podem ser classificados em operacionais e estratégicos, em que os primeiros são focados na eficiência das atividades tradicionais práticas pela empresa, enquanto no segundo o foco se dá a partir do estabelecimento da estratégia organizacional, 
buscando acompanhar e impulsionar a implementação do processo estratégico. Já consoante com o Guia Referencial para Medição de Desempenho e Manual para Construção de Indicadores (BRASIL, 2009), os indicadores podem ser divididos em seis categorias básicas, quais sejam (1) efetividade, relacionada aos impactos gerados pelos produtos/serviços, processos ou projetos; (2) eficácia, relacionada com a quantidade e qualidade dos produtos entregues aos consumidores; (3) eficiência, referente à relação entre os resultados gerados com os insumos empregados; (4) execução, relacionada à realização dos planos de ação, projetos e processos conforme estabelecidos; (5) excelência, concernente à conformidade a critérios e padrões de excelência na realização de projetos e projetos; (6) economicidade, referente à menor utilização de recursos possíveis, atendendo a requisitos previamente exigidos. Tanto na ótica de Lacombe e Albuquerque (2008) quanto na perspectiva do Guia, é importante que a mensuração de desempenho seja realizada de forma ampla, considerando todas as dimensões, objetivando uma apuração mais fidedigna e abrangente para a tomada de decisão.

Corroborando essa visão e cientes da necessidade de utilização, acompanhamento e integração entre os diversos tipos de indicadores para o sucesso organizacional, Kaplan e Norton (2002) desenvolveram o Balanced Scorecard. Essa metodologia tem como objetivo o acompanhamento de indicadores de diversos níveis organizacionais em perspectivas financeira e nãofinanceiras (processos internos, clientes e aprendizagem e crescimento), possibilitando uma avaliação mais profunda de desempenho da organização.

Para que os indicadores sejam úteis à tomada de decisão, Merchant (2006) afirma que diversas características devem ser observadas. A primeira delas referese à congruência, ou seja, a necessidade de indicadores estarem alinhados com os objetivos organizacionais. A segunda característica diz respeito à controlabilidade, ressaltando a importância do indicador ser influenciável e controlável pelo gestor. Ainda segundo o autor, o terceiro aspecto importante é a tempestividade, ou seja, os indicadores devem gerar resultados a tempo de subsidiar a tomada de decisão. $\mathrm{Na}$ quarta característica, é tratada a necessidade de precisão e objetividade por parte do indicador. A quinta característica está resumida na capacidade dos gestores de entender claramente como o indicador é calculado e o que eles podem fazer para influenciar o resultado daquele indicador. Como última característica vital para os indicadores, Merchant (2006) cita a análise do custo benefício, ou 
seja, um indicador só deve ser utilizado caso possa trazer retornos maiores que os custos empregados para sua construção, coleta e monitoramento.

Bazzotti e Garcia (2006) ressaltam, ainda, a importância de sistemas de informação para a apresentação das informações necessárias em tempo hábil para a tomada de decisão, garantindo-as maior qualidade e pontualidade. Além disso, para os autores, devido ao aumento da complexidade do ambiente, a gestão estratégica das informações é parte integrante de qualquer estrutura gerencial de sucesso.

Concordando com os autores supracitados, o $S M M M^{\mathrm{TM}}$ entende a necessidade da mensuração de desempenho, pois sem indicadores de performance os gerentes não possuem informações suficientes para a tomada de decisão mais adequada. Por esse motivo, segundo o modelo, muitas organizações aprenderam a medir alguns aspectos, sejam voltados à parte operacional ou à alguma parte interessada específica. No que tange à mensuração do desempenho estratégico, o $S M M M^{\mathrm{TM}}$ explicita a ocorrência do alinhamento dos indicadores com o planejamento estratégico e não somente com operações diárias da organização. As boas práticas indicadas pelo Modelo que devem estar presentes na mensuração do desempenho estratégico são apresentadas no Quadro 11.

\section{Quadro 11 - Boas práticas na Mensuração de Desempenho}

\begin{tabular}{l} 
Os indicadores precisam ser derivados e estar alinhados com a estratégia, não estando somente \\
ligados à ótica operacional. \\
\hline Os indicadores necessitam estar focados nos produtos e em resultados, não somente em gastos \\
monetários, tarefas cumpridas ou produção entregue. \\
\hline Os indicadores devem utilizar razões, tamanho de amostra e outras características de forma \\
adequada, visando ser mais significativos. \\
Os indicadores precisam ser mensurados e reportados em tempo hábil para auxiliar a tomada de \\
decisão. \\
Os desempenhos da equipe e da organização necessitam ser medidos, além dos desempenhos \\
individuais.
\end{tabular}

Um sistema de indicadores balanceado que englobe diferentes dimensões incluindo não somente dados financeiros, mas também referentes à satisfação do consumidor, ao desempenho dos processos internos e as capacidades da organização deve ser utilizado.

A organização deve possuir sistemas de Tecnologia da Informação em rede para a coleta e distribuição dos indicadores de desempenho que permitem aos usuários verem os dados necessários em tempo hábil para a tomada de decisão.

Fonte: Elaborado pelo autor com base no Strategic Management Maturity Model ${ }^{\mathrm{TM}}$ (Balanced Scorecard Institute, 2010). 
Os níveis de maturidade presentes nesta dimensão, conforme exposto pelo $S M M M^{\mathrm{TM}}$, são:

- Nível 1: Ad Hoc e Estático

○ Não existem indicadores, ou apenas indicadores ad hoc são utilizados.

- Nível 2: Reativo

○ Indicadores de desempenho são utilizados rotineiramente, mas na maioria das vezes com foco em aspectos operacionais.

- Nível 3: Estruturado e Pró-ativo

- Indicadores de desempenho estratégico são utilizados, cobrindo a maioria dos objetivos estratégicos.

- Nível 4: Gerenciado e Focado

- Indicadores estratégicos são amplamente utilizados para melhorar o foco e o desempenho, guiando decisões ligadas ao orçamento.

- Nível 5: Melhoria Contínua

○ Indicadores estratégicos são abrangentemente utilizados e rotineiramente revisados com foco na melhoria contínua.

\subsubsection{6.}

\section{Gerenciamento de Desempenho}

Bryson (2011) relata a importância da efetiva utilização dos indicadores para o gerenciamento do desempenho organizacional. Segundo o autor, para que tal ação aconteça de maneira correta os indicadores devem ser comunicados e a aprendizagem deve ser estimulada dentro da organização.

Ciente da necessidade da aprendizagem para o sucesso organizacional, Senge (2002), em "A Quinta Disciplina", discorre sobre as disciplinas que uma organização que busca o aprendizado possui, são elas:

- Domínio pessoal, responsável pelo esclarecimento e aprofundamento contínuo dos objetivos pessoais, concentração das energias, desenvolvimento da paciência e observação da realidade de forma objetiva. Tal disciplina incentiva o autoconhecimento e autocontrole, possibilitando ao indivíduo uma análise racional das situações e decisões analisadas; 
- Modelos mentais, relacionados com suposições e generalizações de como o indivíduo vê o mundo, influenciando sua forma de pensar. Nessa disciplina, o indivíduo é incentivado a pensar de forma diferente, exercitando pontos de vista diversos;

- Visão compartilhada, relacionada à utilização de objetivos, valores, visão e missão comuns por toda a organização. Tal disciplina visa o estabelecimento de diretrizes estratégicas comuns para toda organização buscando o contínuo aprendizado, proporcionando foco e energia para aprendizagem;

- Aprendizagem em grupo, relacionada à utilização do diálogo e da discussão em equipe. Nessa disciplina, os indivíduos buscam a troca de experiências para que todos possam compartilhar conhecimentos, a fim de superar as percepções individuais;

- Pensamento sistêmico, responsável por integrar as demais disciplinas possibilitando uma visão holística por parte da organização. Tal disciplina estimula o entendimento da organização não como um parte isolada, mas como parte de um todo.

O $S M M M^{\mathrm{TM}}$ entende que mensurar o desempenho e utilizar as informações geradas por essa mensuração são coisas diferentes. $O$ gerenciamento de desempenho lida com o grau em que os indicadores de desempenho são utilizados para a tomada de decisão. Para o correto gerenciamento de desempenho, o modelo entende que as boas práticas citadas no Quadro 12 devem ser seguidas.

\section{Quadro 12 - Boas práticas no Gerenciamento de Desempenho}

\begin{tabular}{|c|}
\hline A organização deve ser reconhecida como um sistema dinâmico. \\
\hline $\begin{array}{l}\text { A organização precisa utilizar ciclos de feedbacks para que os gerentes possam ter ciência dos } \\
\text { resultados das suas decisões. }\end{array}$ \\
\hline $\begin{array}{l}\text { Os gestores devem ser capazes de fazer mudanças com base em relatórios apresentados em tempo } \\
\text { hábil. }\end{array}$ \\
\hline Os indicadores de desempenho estratégico necessitam estar disponíveis para avaliar a estratégia. \\
\hline Os líderes colocam a organização em um ciclo de aprendizagem. \\
\hline A organização deve aprender o que funciona para satisfazer o consumidor e melhorar a organização. \\
\hline
\end{tabular}


Os diferentes níveis de maturidade dentro desta dimensão, conforme constante no $S M M M^{\mathrm{TM}}$, são:

- Nível 1: Ad Hoc e Estático

- Nenhuma ênfase é dada na utilização de indicadores de desempenho como um critério para gerir a organização.

- Nível 2: Reativo

○ Análises de desempenho são solicitadas, porém não são levadas à sério. Não existe responsabilidade sobre o desempenho aferido.

- Nível 3: Estruturado e Pró-ativo

○ Os indicadores são alocados a 'donos', sendo o desempenho acompanhado no nível individual e organizacional.

- Nível 4: Gerenciado e Focado

○ Os 'donos' são responsabilizados e o desempenho é gerido em todos os níveis.

- Nível 5: Melhoria Contínua

- A medição e a responsabilidade fazem parte da cultura organizacional, sendo as decisões baseadas em evidências.

\subsubsection{7. \\ Melhoria de Processos}

Segundo a Notação de Modelagem de Processos de Negócio (BPMN Business Process Model Notation, 2011), entende-se processo como uma sequência ou um fluxo de atividades dentro de uma organização com o objetivo de realizar um trabalho. Dentro do âmbito de processos, o Guia para o Gerenciamento de Processos de Negócio Corpo Comum de Conhecimento (BPM CBOK - Business Process Management Common Body of Knowledge, 2009) define processos de negócios como um trabalho que entrega valor para os clientes ou apoia/gerencia outros processos, podendo ser classificado em: (1) primários, focados em processos essenciais ou finalísticos, representando as atividades essenciais da organização e construindo a percepção de valor por parte do cliente; (2) de suporte, com o objetivo de auxiliar os processos primários, os processos de gerenciamento e outros processos de suporte; (3) de gerenciamento, com o 
propósito de desenhar, implementar, monitorar, controlar e melhorar continuamente outros processos de negócio.

Buscando o alcance dos objetivos organizacionais por meio da definição, desenho, controle e transformação contínua dos processos de negócios a disciplina de Gerenciamento de Processos de Negócios (BPM - Business Process Management) foi desenvolvida. O BPM CBOK (2009) define o BPM, como:

\begin{abstract}
Uma disciplina gerencial que integra estratégias e objetivos de uma organização com expectativas e necessidades de clientes, por meio do foco em processos de ponta a ponta. BPM engloba estratégias, objetivos, cultura, estruturas organizacionais, papéis, políticas, métodos, e tecnologias para analisar, desenhar, implementar, gerenciar desempenho, transformar e estabelecer a governança de processos (BPM CBOK, 2009, p.52).
\end{abstract}

No âmbito do BPM, o Modelo de Referência de Valor (VRM - Value Reference Model), focado na cadeia de valor, discorre sobre os níveis (estratégicos, táticos e operacionais) dos processos da cadeia de valor. Nessa esfera, os processos estratégicos são os mais altos da cadeia de valor, desenhados especificamente em torno das necessidades dos clientes e da estratégia do negócio (BPM CBOK, 2009).

Cientes da necessidade da avaliação, comparação e melhoria continua dos processos de negócio, Baldam et al. (2007) descrevem benchmarking como uma técnica capaz de auxiliar as organizações a atingir tais objetivos. Os autores definem essa técnica como:

\footnotetext{
uma maneira sistemática de definir, entender e evoluir criativamente produtos, projetos, equipamentos, processos e práticas de uma operação por meio do estudo de como outras organizações desempenhar essa mesma operação, ou operação semelhante (Baldam et al., 2007, p. 87).
}

No que tange aos processos de negócio, outro ponto importante é a análise de risco. Essa análise busca examinar o que aconteceria a determinado processo caso eventos diversos impactassem a organização. Os riscos podem ser verificados por meio de uma matriz que correlacione a probabilidade de ocorrência com o impacto para a organização. É fundamental para a análise de riscos, a análise do plano de contingência e de suas possíveis consequências (BPM CBOK, 2009). 
Conforme exposto no $S M M M^{\mathrm{TM}}$, o papel da gestão estratégica, nessa dimensão, é identificar quais são os processos pertencentes ao portfólio que necessitam, com maior urgência, de melhorias, priorizando os processos mais relevantes estrategicamente. Segundo o modelo, a melhoria dos processos de trabalho deve ter como base as práticas citadas no Quadro 13.

\section{Quadro 13 - Boas práticas em Melhoria de Processos}

A organização deve conhecer sobre seus processos de trabalho estrategicamente importantes.

Os processos estrategicamente importantes devem ser atualizados e documentados de forma contínua.

Os processos estrategicamente importantes precisam ser eficientes quando comparados com organizações similares.

As habilidades, práticas e tecnologias necessitam ser empregadas com vistas à melhora da qualidade e eficiência dos processos.

A organização deve conhecer suas competências centrais e capacidades e o quão bem elas são empregadas na execução dos processos.

Os funcionários devem conhecer os clientes da organização e suas expectativas.

Planos de contingência referentes a riscos futuros, como desastres, escassez de financiamento e sucessão de liderança precisam existir dentro da organização.

Fonte: Elaborado pelo autor com base no Strategic Management Maturity Model ${ }^{\mathrm{TM}}$ (Balanced Scorecard Institute, 2010)

Os níveis de maturidade presentes nesta dimensão, conforme exposto pelo $S M M M^{\mathrm{TM}}$, são:

- Nível 1: Ad Hoc e Estático

○ Os processos não são documentados e são $a d$ hoc com duplicações e atrasos.

- Nível 2: Reativo

- Apenas alguns processos chaves são documentados e alguns modelos de melhoria de processos são introduzidos.

- Nível 3: Estruturado e Pró-ativo

○ Todos os processos chaves são identificados e documentados, sendo a estratégia a guia para iniciativas de melhoria nos processos. 
- Nível 4: Gerenciado e Focado

- Todos os processos chaves da organização são acompanhados e melhorados continuamente. Ideias novas para a melhoria dos processos são aceitas.

- Nível 5: Melhoria Contínua

○ Os funcionários são empoderados e treinados. Além disso, existe um processo formal para a melhoria contínua dos processos de gestão.

\subsubsection{8.}

\section{Sustentabilidade do Gerenciamento Estratégico}

A gestão estratégica deve ser vista como um processo contínuo e retroalimentável, devendo ser perene para que as metas e os objetivos organizacionais sejam atingidos (CAMARGOS e DIAS, 2003).

Segundo Bryson (2010), a existência de líderes mobilizadores, conhecidos também como campeões, é vital para que a sustentabilidade da gestão estratégica seja alcançada. Para o autor, esses indivíduos são os principais responsáveis por gerenciar o processo estratégico diário, devendo: (1) manter o foco dos funcionários no planejamento estratégico; (2) atuar como promotores do processo estratégico como um todo, não defendendo qualquer solução específica; (3) pensar sobre o quê juntar (pessoas, tarefas, informações, relatórios) antes ou no momento de decisões estratégicas; (4) organizar os recursos necessários, como tempo, espaço, materiais e a participação dos funcionários, para que a gestão estratégica seja bem sucedida; (5) prestar atenção na linguagem utilizada para descrever a gestão estratégica; (6) incentivar a participação dos envolvidos no processo estratégico; (7) buscar outros líderes mobilizadores que possam auxiliá-lo dentro da organização; (8) ser sensível a diferenças de poder.

Visando a sustentabilidade do processo de gestão estratégica, Rotharmel (2015) explica a importância dos sistemas de recompensa e reconhecimento. Para o autor, esses sistemas permitem que os gestores especifiquem objetivos, mensurem progresso e ofereçam feedback aos funcionários sobre o próprio desempenho, com vistas a motivá-los para o cumprimento de seus objetivos.

Kaplan e Norton (2002) ressaltam a importância do envolvimento de todos da organização com a gestão estratégica. Para os autores, visando o atingimento 
do melhor resultado no âmbito estratégico, todos na empresa devem compreender a estratégia e como suas ações individuais sustentam o conjunto estratégico, buscando o entendimento e o comprometimento compartilhados por todos os integrantes da organização.

Em virtude da importância da gestão estratégica e de sua natureza contínua, diversas organizações, como o Conselho Nacional de Justiça - CNJ, o Instituto de Pesquisa Econômica Aplicada - IPEA, o Instituto Nacional de Colonização e Reforma Agrária - INCRA, o Ministério Público Federal - MPF e a Superintendência de Seguros Privados - SUSEP, possuem unidades responsáveis por atuar no planejamento, coordenação e monitoramento do processo de gerenciamento estratégico.

O $S M M M^{\mathrm{TM}}$ define critérios para que o processo de gestão estratégica seja sustentável. Para tal, as práticas constantes no Quadro 14 devem ser observadas.

Quadro 14 - Boas práticas na Sustentabilidade do Gerenciamento Estratégico

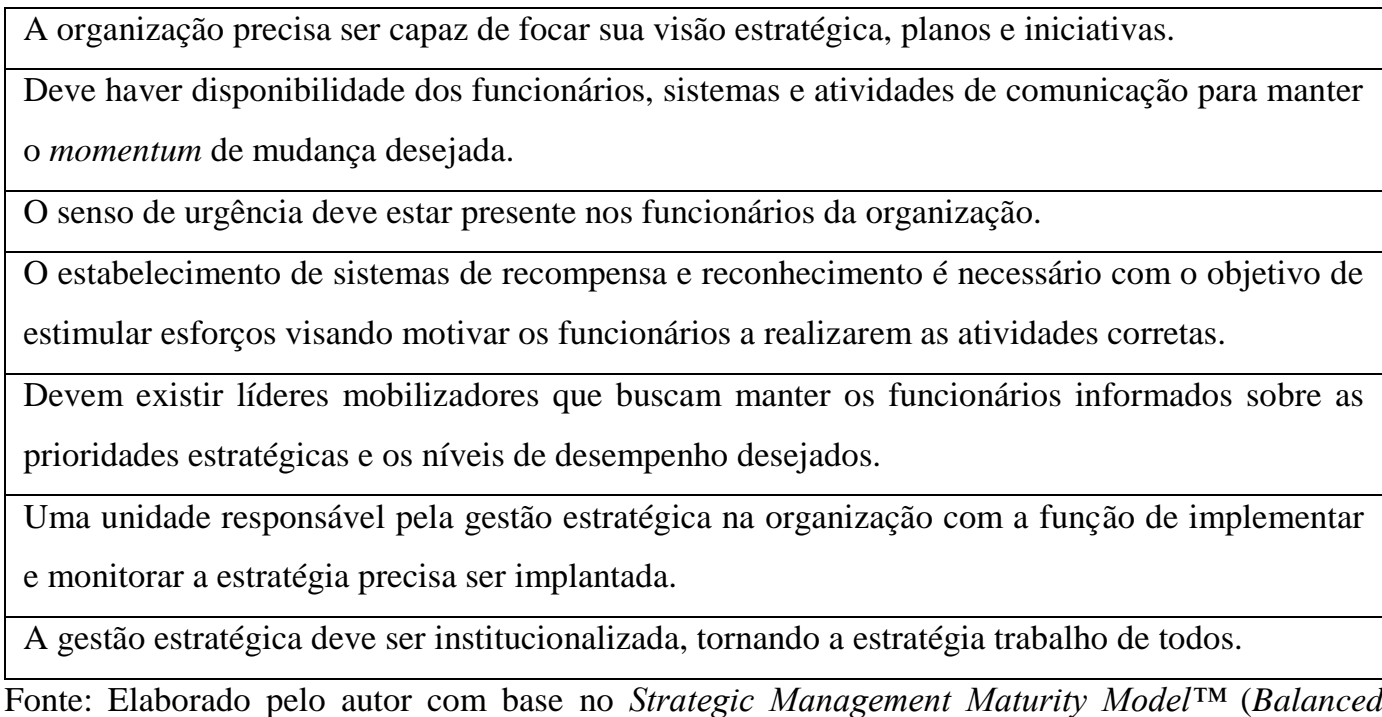
Scorecard Institute, 2010).

Os diferentes níveis de maturidade dentro desta dimensão, conforme constante no $S M M M^{\mathrm{TM}}$, são:

- Nível 1: Ad hoc e Estático

- Falta de estrutura e líderes mobilizadores atuando em tarefas de curto prazo.

- Nível 2: Reativo

○ Os líderes mobilizadores são identificados. 
- Nível 3: Estruturado e Pró-ativo

- A organização formal está estruturada para manter o foco na estratégia.

- Nível 4: Gerenciado e Focado

- A organização possui uma unidade de gestão estratégica ou equivalente.

- Nível 5: Melhoria Contínua

○ O pensamento e a gestão estratégica estão enraizados na cultura organizacional. 


\section{3 \\ Metodologia}

Esse Capítulo tratará das questões metodológicas deste estudo, expondo questões como abordagem, técnica e delineamento de pesquisa, os procedimentos de coleta e tratamento de dados e os procedimentos utilizados para análise dos dados.

\section{1. \\ Delineamento da Pesquisa}

Para a realização deste estudo, optou-se pela utilização da abordagem de pesquisa qualitativa. Creswell (2010) indica que, quando um fenômeno precisa ser mais bem entendido, como é o caso do tema abordado (avaliação de maturidade em gestão estratégica) nesta dissertação, ou um quando há pouca pesquisa acerca de um conceito, a pesquisa qualitativa é a abordagem mais apropriada.

Em relação à técnica de pesquisa, a escolhida foi o estudo de casos múltiplos incorporados. Para Yin (2003), o estudo de caso pode ser entendido como uma investigação empírica de um fenômeno contemporâneo dentro de um contexto da vida real. Ainda segundo o autor, essa técnica pode ser usada, dentre outras, com as seguintes finalidades:

- Ilustrar determinados tópicos dentro de uma avaliação;

- Explorar situações nas quais a intervenção que está sendo avaliada não apresenta um conjunto simples e claro de resultados.

O autor divide os estudos de caso em quatro tipos básicos, sendo eles:

- Projetos de caso único holístico - unidade única de análise e único caso (ex. caso extremo, único, ou corriqueiro);

- Projetos de caso único incorporado - unidades múltiplas de análise e único caso (ex. análise de diversas áreas dentro de uma única empresa); 
- Projetos de casos múltiplos holísticos - unidade única de análise e múltiplos casos (ex. análise da mesma área ou problema, dentro de múltiplas empresas);

- Projetos de casos múltiplos incorporados - unidades múltiplas de análise e múltiplos casos (ex. análise de diversas áreas ou dimensões, dentro de múltiplas empresas).

Os projetos de casos múltiplos holísticos ou incorporados são, em geral, mais indicados, com algumas exceções (ex. caso extremo, único, ou corriqueiro), pois possibilitam a análise e a comparação de múltiplas unidades ou casos, objetivando identificar semelhanças e diferenças. Além disso, a vulnerabilidade de "colocar todos os ovos em uma única cesta" é um aspecto relevante a se considerar ao pensar na estrutura de pesquisa desejada (YIN, 2003).

Esta pesquisa divide-se em quatro fases. Na primeira fase, foi utilizada a pesquisa bibliográfica. Essa fase objetivou conhecer e delimitar, de forma mais precisa, o problema de pesquisa, verificando o que foi publicado a respeito do tema abordado neste estudo, como o conceito de gestão estratégica, os novos paradigmas de gestão da administração pública, as possíveis dimensões que perpassam o processo de gestão estratégica e os possíveis métodos existentes na literatura para avaliação da maturidade do processo de gestão estratégica.

$\mathrm{Na}$ segunda fase, o $S M M M^{\mathrm{TM}}$ foi escolhido para servir como base para a apuração do nível de maturidade da gestão estratégica e adaptado para possibilitar uma visão mais completa e pormenorizada dessa gestão dentro das organizações estudadas. Nesta fase, foi elaborado o questionário de pesquisa, no qual as boas práticas para cada uma das oito dimensões, descritas no modelo, foram transformadas em afirmações para serem avaliadas por meio da escala Likert, ampliando a quantidade de questionamentos de oito para 51. Além disso, foram incluídas 16 perguntas abertas, duas por dimensão. Esse questionário foi testado por três servidores - cujas respostas não serão consideradas na análise dos resultados - para verificar a consistência e efetuar possíveis correções.

$\mathrm{Na}$ terceira fase, foram escolhidas as organizações participantes do estudo, assim como os servidores que responderiam ao questionário. Com o objetivo de avaliar a percepção da equipe de gestão estratégica (ou afim) da organização, mas sem deixar de ouvir os servidores de outras áreas, foram entrevistados dois 
integrantes da área de gestão estratégica (ou afim) e dois integrantes de áreas distintas em cada uma das organizações.

A quarta e última fase consistiu na apuração dos resultados dos questionários, apontando qual é a avaliação, por parte dos representantes da equipe de gestão estratégica (ou afim), das outras áreas e desses dois grupos conjuntamente, de cada dimensão identificada no $S M M M^{\mathrm{TM}}$ e da gestão estratégica no âmbito da sua organização. Para complementar essa pesquisa, as dificuldades e sugestões de melhorias explicitadas pelos respondentes no âmbito das dimensões foram transcritas e analisadas. A Figura 3 apresenta um esquema resumido com as fases de pesquisas propostas.

Figura 3 - Delineamento da pesquisa

\section{$\underline{\text { Fase } 1}$}

- $\quad$ Pesquisa bibliográfica

○ Referencial Teórico

- Administração Pública;

- Gestão Estratégica;

- $S M M M^{\mathrm{TM}}$.

\section{Fase 2}

- Elaboração do questionário de pesquisa

- Escolha e adaptação do modelo base (SMMMTM);

○ Inclusão de perguntas abertas.

$\underline{\text { Fase } 3}$

- Seleção das organizações e dos participantes respondentes.

- Aplicação do questionário de pesquisa

\section{$\underline{\text { Fase } 4}$}

- Análise dos questionários de pesquisa

- Avaliação do nível de maturidade nas dimensões abordadas e na gestão estratégica;

- Apresentação e análise das dificuldades e sugestões de melhorias elencadas pelos respondentes. 


\section{2. Procedimentos de Coleta e Tratamento de Dados}

A pesquisa bibliográfica foi o ponto de partida para a construção de um referencial adequado que subsidiasse a elaboração deste estudo. Nessa pesquisa foram utilizadas fontes de informação diversas (artigos, estudos de caso, livros, normas constitucionais e infraconstitucionais e tese) com o objetivo de enriquecer o debate sobre o tema abordado.

No decurso da pesquisa bibliográfica, buscou-se conceituar e discorrer sobre a administração pública e sua nova forma de gestão (voltada a resultados), analisar e descrever o conceito de gestão estratégica e verificar as formas encontradas, seja na academia ou no campo, para a avaliação de maturidade no âmbito da gestão estratégica, entendida como passo inicial para a otimização do gerenciamento estratégico, uma vez que, para que haja melhora, deve-se entender os pontos fortes e fracos do processo.

A partir do estudo da literatura sobre o tema, o $S M M M^{\mathrm{TM}}$ foi encontrado e escolhido para servir como base para o desenvolvimento deste trabalho pelos motivos descritos na seção 2.3. Uma das principais características do questionário do Modelo é a rapidez de avaliação, tal característica, embora sirva como ponto de partida para que a organização analisada reflita e conheça um pouco mais sobre o próprio processo de gestão estratégica, não permite que os assuntos sejam aprofundados da maneira desejada por esse estudo. Por conseguinte, foram feitas adaptações no modelo para que ele se tornasse mais profundo e permitisse a extração de um maior número de informações sobre o processo de gestão estratégica. Nessa adaptação, as orientações gerais dadas no próprio modelo foram transformadas em afirmações para verificar em que medida as organizações analisadas estão alinhadas com as boas práticas delineadas no $S M M M^{\mathrm{TM}}$. Além disso, com o objetivo de avaliar de forma mais detalhada o tema, duas perguntas abertas que discorreram sobre as principais dificuldades e possíveis soluções de melhorias foram colocadas em cada uma das oito dimensões estudadas, totalizando 16 questões abertas. No total, os oito questionamentos iniciais foram transformados em 67, sendo 51 respondidos seguindo a escala Likert e 16 por perguntas abertas. 
A adoção da escala Likert, quase exclusivamente utilizada como uma de forma de coleta de dados em estudos quantitativos, serve para possibilitar, neste estudo, apesar do seu cunho qualitativo, que os respondentes sejam capazes de avaliar uma maior gama de informações, uma vez que 67 perguntas abertas inviabilizariam a realização da maior parte, se não de todos, estudos acadêmicos. Além disso, pela escala Likert é possível quantificar as informações coletadas, possibilitando que haja a avaliação de maturidade em gestão estratégica da organização analisada nos mesmos moldes do $S M M M^{\mathrm{TM}}$, embora sem validade estatística devido a amostragem reduzida e intencional.

O questionário com as 67 questões, apresentado no Apêndice A, foi encaminhado em versões de Microsoft Excel (2007) e Microsoft Word (2007) via e-mail para os 12 respondentes. Todas as dúvidas sobre conceitos utilizados foram esclarecidas por e-mail ou telefone diretamente com o autor. Para cada organização analisada, foram selecionados dois respondentes da área de gestão estratégica (ou afim) e dois respondentes de áreas diversas. Tal segmentação foi realizada pelas seguintes razões:

- A área de gestão estratégica (ou afim) é vital para a realização deste estudo, pois ela possui o conhecimento necessário para afirmar sobre o nível que determinada prática vem sendo utilizada dentro da organização;

- A escolha de respondentes de outras áreas tem como objetivo avaliar se as respostas dadas pelos representantes da área de gestão estratégica estão em consonância com a percepção dos demais funcionários que não estão diretamente ligados ao tema. Como os funcionários de outras áreas podem não ter conhecimento sobre o andamento de algumas das práticas ligadas à gestão estratégica dentro de sua organização, a opção "6 - não tenho como avaliar" foi incluída na escala Likert.

As informações coletadas a partir do recebimento dos questionários preenchidos foram analisados de modo descrito na seção seguinte (Procedimentos para Análise dos Dados). 


\section{3. Procedimentos de Análise de Dados}

Os resultados dos questionários foram tabulados no Microsoft Excel e a análise dos dados apurados por meio da escala Likert foi feita em três partes. Nas três partes, as respostas foram agregadas em três categorias: (1) respondentes da área de gestão estratégica - identificada, para preenchimento de tabelas e quadros, como E; (2) respondentes das demais áreas - identificada, para preenchimento de tabelas e quadros, como D; e (3) respondentes no geral, agregando as duas categorias anteriores - identificada, para preenchimento de tabelas e quadros, como G. Para garantir o anonimato das organizações e dos representantes participantes, não há identificação direta em nenhum dos dois casos, sendo as organizações analisadas identificadas com $\mathrm{O} 1, \mathrm{O} 2, \mathrm{O} 3$ e os respondentes como R1, R2, R3, R4.

Na primeira parte, para tal agregação, foi usada a média entre a marcação dos respondentes, apontando assim um número único para cada uma das orientações no âmbito de cada categoria.

$\mathrm{Na}$ segunda parte, todas as marcações correspondentes às orientações gerais pertencentes a determinada dimensão foram somadas e divididas pelo número de respostas recebidas (com exceção de marcações identificadas como "6não tenho como avaliar), possibilitando a categorização da dimensão em um dos cinco níveis apontados pelo modelo. Seguindo forma de cálculo semelhante à usada no $S M M M^{\mathrm{TM}}$, o nível de maturidade intra-dimensão pode ser resumido no Quadro 15.

Quadro 15 - Níveis de maturidade Intra-Dimensão

\begin{tabular}{|c|c|}
\hline Níveis de Maturidade & Pontuação \\
\hline Ad Hoc ou Estático & Entre 1 e 1,49 \\
\hline Reativo & Entre 1,5 e 2,49 \\
\hline Estruturado e Pró-ativo & Entre 2,5 e 3,49 \\
\hline Gerenciado e Focado & Entre 3,5 e 4,49 \\
\hline Melhoria Contínua & Entre 4,5 e 5 \\
\hline
\end{tabular}


Na última parte, os valores obtidos em cada dimensão foram somados, possibilitando a avaliação do nível de maturidade em gestão estratégica de cada organização. Seguindo forma de cálculo semelhante à usada no $S M M M^{\mathrm{TM}}$, o nível de maturidade da organização pode ser resumido no Quadro 16.

Quadro 16 - Níveis de maturidade em gestão estratégica

\begin{tabular}{|c|c|}
\hline Níveis de Maturidade & Pontuação \\
\hline Ad Hoc ou Estático & Entre 8 e 11,99 \\
\hline Reativo & Entre 12 e 19,99 \\
\hline Estruturado e Pró-ativo & Entre 20 e 27,99 \\
\hline Gerenciado e Focado & Entre 28 e 35,99 \\
\hline Melhoria Contínua & Entre 36 e 40 \\
\hline
\end{tabular}

No que diz respeito às questões abertas, elas foram inicialmente apresentadas individualmente, em tabelas, possuindo a identificação da organização, da área de gestão estratégica ou das demais áreas e do respondente. É relevante ressaltar, ainda, que essas questões servem como complemento das informações registradas na escala Likert. Logo, os respondentes tinham a opção de registrar várias dificuldades ou sugestões de melhorias ou nenhuma delas, se julgassem que não havia nada a acrescentar. O conteúdo dessas respostas foram analisados com auxílio do software Atlas.ti (versão 7.5.16), o que possibilitou a identificação e categorização de informações semelhantes obtidas dos questionários. Conforme Muhr (1991), o Atlas.ti oferece apoio aos investigadores sociais para as atividades que envolvem a interpretação de texto, incluindo a gestão de anotações, conceitos e estruturas complexas, assim como as relações conceituais que emergem do processo de interpretação. 


\section{4 \\ Avaliação do Nível de Maturidade em Gestão Estratégica das Organizações Estudadas}

Esse Capítulo tem como objetivo analisar o grau de maturidade em gestão estratégica de três diferentes entidades públicas federais, com base nas respostas de quatro entrevistados por instituição. A primeira seção trata exclusivamente da caracterização das organizações analisadas, enquanto a segunda e a terceira seções preocupam-se com a análise dos resultados, buscando identificar esse grau de maturidade em cada uma das organizações focalizadas. Na segunda seção, é realizada a avaliação comparativa dos resultados obtidos dentro de cada dimensão do $S M M M^{\mathrm{TM}}$, pelos quais será possível verificar o nível de maturidade de cada instituição nessas dimensões. Além disso, nessa seção, são descritas e categorizadas as principais dificuldades e as soluções de melhoria indicadas pelos respondentes dentro de suas organizações. Na terceira seção, análise semelhante é realizada, porém levando-se em conta as dimensões de forma conjunta, ou seja, o processo de gestão estratégica por completo.

\section{1.}

\section{Caracterização das Organizações Analisadas}

Para a realização dessa pesquisa, três organizações públicas foram estudadas, são elas:

- Banco Central do Brasil

- Autarquia federal vinculada ao Ministério da Fazenda, tendo como finalidades: organizar, disciplinar e fiscalizar o Sistema Financeiro Nacional e o Sistema de Consórcio; formular, executar, acompanhar e controlar as políticas cambial, creditícia, monetária e de relações financeiras com o externo; gerir o Sistema de Pagamentos Brasileiro e os serviços de meio circulante (PORTARIA No 84.287, 2015). 
- Banco Nacional de Desenvolvimento Econômico e Social

- Empresa pública sujeita à supervisão do Ministro de Estado do Desenvolvimento, Indústria e Comércio Exterior, tendo como finalidade: apoiar programas, projetos, obras e serviços que se relacionem com o desenvolvimento econômico e social do país. As atividades de competência do BNDES serão exercidas, objetivando estimular a iniciativa privada, sem prejudicar o apoio de empreendimentos de interesse nacional de responsabilidade do setor público (DECRETO N 4.418, 2002).

- Fundação Instituto Brasileiro de Geografia e Estatística

- Função pública vinculada ao Ministério do Planejamento, Desenvolvimento e Gestão, tendo como missão, conforme previsto no $\operatorname{artigo} 2^{\circ}$ do Decreto ${ }^{\circ} 4.740$ (2013):

Retratar o Brasil com informações necessárias ao conhecimento da sua realidade e ao exercício da cidadania, por meio da produção, análise, pesquisa e disseminação de informações de natureza estatística demográfica e socioeconômica, e geocientífica - geográfica, cartográfica, geodésica e ambiental.

\section{2.}

\section{Análise Comparativa dos Resultados por Dimensão}

Os quadros e tabelas desta seção foram desenvolvidos com o objetivo de avaliar as dimensões individualmente, a partir das opiniões dos respondentes, tanto da área de gestão estratégica, quanto das demais áreas. Nas tabelas, são observadas as médias das respostas dadas pelos colaboradores entrevistados que atuam na área de gestão estratégica (E) ou nas demais áreas (D), assim como o resultado geral (G) em cada uma das questões abordadas. Nessas tabelas são apresentados, também, os valores referentes aos níveis de maturidade atingidos por cada organização em cada uma das dimensões, considerando individualmente a área de gestão estratégica, as demais áreas e o resultado geral. Já no que concerne aos Quadros, eles expõem as principais dificuldades e soluções de melhorias indicadas pelos respondentes em suas organizações no âmbito da dimensão analisada. 


\subsection{1.}

Liderança

Com base no $S M M M^{\mathrm{TM}}$ e na análise da Tabela 1 , observa-se que as três organizações classificam-se como estruturadas e pró-ativas (com pontuação entre 2,5 e 3,49), conforme pode ser observado no Quadro 15. Tal nível de maturidade é o terceiro em uma escala de um a cinco, representando assim um nível mediano de desenvolvimento na dimensão Liderança.

Tabela 1 - Respostas dos questionários na dimensão Liderança

\begin{tabular}{|c|c|c|c|c|c|c|c|c|c|}
\hline & O1E & O1D & $\mathrm{O} 1 \mathrm{G}$ & $\mathrm{O} 2 \mathrm{E}$ & $\mathrm{O} 2 \mathrm{D}$ & $\mathrm{O} 2 \mathrm{G}$ & $\mathrm{O} 3 \mathrm{E}$ & O3D & $\mathrm{O} 3 \mathrm{G}$ \\
\hline $\begin{array}{lcr}\text { Os líderes } & \text { definem uma } \\
\text { visão de futuro clara } & \text { e } \\
\text { consistente } & \text { sobre } & \text { a } \\
\text { organização. } & & \\
\end{array}$ & 3,00 & 4,50 & 3,75 & 4,00 & 3,00 & 3,50 & 3,50 & 2,50 & 3,00 \\
\hline $\begin{array}{l}\text { Os líderes são pró-ativos na } \\
\text { preparação da organização } \\
\text { para o futuro. }\end{array}$ & 3,00 & 3,00 & 3,00 & 3,50 & 2,00 & 2,75 & 2,00 & 3,00 & 2,50 \\
\hline $\begin{array}{l}\text { Os líderes são acessíveis e } \\
\text { engajados para garantir o } \\
\text { entendimento, por parte dos } \\
\text { funcionários, de uma visão } \\
\text { comum e para que eles } \\
\text { consigam traduzi-la em } \\
\text { termos relevantes para a } \\
\text { execução dos trabalhos. }\end{array}$ & 2,50 & 3,00 & 2,75 & 3,50 & 2,50 & 3,00 & 4,00 & 4,00 & 4,00 \\
\hline $\begin{array}{l}\text { Os líderes são consistentes } \\
\text { entre o que dizem e o que } \\
\text { fazem no que diz respeito } \\
\text { aos valores, à ética e às } \\
\text { políticas da organização. }\end{array}$ & 3,50 & 3,50 & 3,50 & 4,50 & 4,00 & 4,25 & 4,00 & 4,50 & 4,25 \\
\hline $\begin{array}{l}\text { Os líderes } \\
\text { microgerenciam, preferem } \\
\text { confiar e encorajar os } \\
\text { funcionários a contribuir } \\
\text { com ideias e estimular o } \\
\text { crescimento em suas } \\
\text { carreiras. }\end{array}$ & 2,50 & 2,50 & 2,50 & 4,50 & 2,50 & 3,50 & 2,00 & 3,50 & 2,75 \\
\hline $\begin{array}{l}\text { Os líderes interagem e } \\
\text { trabalham lado a lado com } \\
\text { os funcionários, estimulando } \\
\text { o trabalho em equipe. }\end{array}$ & 2,50 & 3,50 & 3,00 & 4,00 & 2,50 & 3,25 & 2,50 & 3,50 & 3,00 \\
\hline Nível de Maturidade & 2,83 & 3,33 & 3,08 & 4,00 & 2,75 & 3,38 & 3,00 & 3,50 & 3,25 \\
\hline
\end{tabular}

No Quadro 17, são relacionadas as principais dificuldades apontadas pelos respondentes na dimensão Liderança. 
Quadro 17 - Principais dificuldades na dimensão Liderança

\begin{tabular}{|c|c|c|c|}
\hline Organização & Área & Respondente & Descrição \\
\hline O1 & $\mathrm{E}$ & $\mathrm{R} 1$ & $\begin{array}{l}\text { Os líderes, na sua maioria, têm perfil técnico e não } \\
\text { exploram adequadamente as competências da equipe, } \\
\text { deixando de motivá-la e atentá-la às questões } \\
\text { estratégicas da instituição. }\end{array}$ \\
\hline $\mathrm{O} 1$ & $\mathrm{E}$ & $\mathrm{R} 2$ & $\begin{array}{l}\text { Há dificuldade, por parte dos líderes, de lidar com a } \\
\text { motivação das pessoas, que em função da estabilidade, } \\
\text { não apresentam resultados esperados. }\end{array}$ \\
\hline O1 & $\mathrm{E}$ & $\mathrm{R} 2$ & $\begin{array}{l}\text { Existem poucas ferramentas/mecanismos de premiação } \\
\text { que os líderes possam utilizar para reconhecer o } \\
\text { sucesso de um membro da equipe. }\end{array}$ \\
\hline O1 & $\mathrm{D}$ & $\mathrm{R} 3$ & $\begin{array}{l}\text { Os líderes centralizam as atividades sob sua } \\
\text { responsabilidade. }\end{array}$ \\
\hline O1 & $\mathrm{D}$ & $\mathrm{R} 4$ & $\begin{array}{l}\text { Os líderes não conseguem traduzir a visão comum para } \\
\text { a execução dos trabalhos diários. }\end{array}$ \\
\hline $\mathrm{O} 2$ & $\mathrm{E}$ & $\mathrm{R} 1$ & $\begin{array}{l}\text { Os líderes perdem a visão do todo, possuindo, } \\
\text { portanto, visões difusas, preocupando-se, assim, } \\
\text { somente com seu departamento ou área de atuação. }\end{array}$ \\
\hline $\mathrm{O} 2$ & $\mathrm{E}$ & $\mathrm{R} 2$ & $\begin{array}{l}\text { O perfil de liderança, em geral, é muito técnico. } \\
\text { Assim, a ascensão gerencial é muitas vezes baseada, } \\
\text { somente, na competência técnica. }\end{array}$ \\
\hline $\mathrm{O} 2$ & $\mathrm{D}$ & R3 & $\begin{array}{l}\text { Existe pouca autonomia e delegação quanto se trata de } \\
\text { tarefas importantes, principalmente no concerne aos } \\
\text { colaboradores de níveis organizacionais mais baixos. }\end{array}$ \\
\hline $\mathrm{O} 2$ & $\mathrm{D}$ & R3 & $\begin{array}{l}\text { Os funcionários são valorizados pelo tempo de } \\
\text { possuem dentro da organização. }\end{array}$ \\
\hline $\mathrm{O} 2$ & $\mathrm{D}$ & $\mathrm{R} 4$ & $\begin{array}{l}\text { Existem dificuldade no âmbito do gerenciamento e da } \\
\text { motivação da equipe, uma vez que os líderes são } \\
\text { alçados à função gerencial apenas por competência } \\
\text { técnica e não pela competência interpessoal. }\end{array}$ \\
\hline $\mathrm{O} 3$ & $\mathrm{E}$ & $\mathrm{R} 1$ & $\begin{array}{l}\text { Falta de maturidade executiva. Os líderes têm como } \\
\text { único critério para ascensão sua competência técnica, } \\
\text { não possuindo, muitas vezes, competências necessárias } \\
\text { para efetivamente gerir pessoas. }\end{array}$ \\
\hline $\mathrm{O} 3$ & $\mathrm{E}$ & $\mathrm{R} 1$ & $\begin{array}{l}\text { Os líderes possuem visão feudal. Logo, preocupando- } \\
\text { se somente com seu departamento ou área funcional. }\end{array}$ \\
\hline $\mathrm{O} 3$ & $\mathrm{E}$ & $\mathrm{R} 2$ & $\begin{array}{l}\text { Os líderes não são pró-ativos na preparação da } \\
\text { organização para o futuro. }\end{array}$ \\
\hline
\end{tabular}


Quadro 17 - Principais dificuldades na dimensão Liderança (continuação)

\begin{tabular}{|c|c|c|l|}
\hline Organização & \multicolumn{2}{|c|}{ Área } & \multicolumn{2}{c|}{ Desponcrição } \\
\hline O3 & E & R2 & $\begin{array}{l}\text { Os líderes microgerenciam as atividades sob suas } \\
\text { responsabilidades. }\end{array}$ \\
\hline O3 & D & R3 & $\begin{array}{l}\text { As posições de liderança são ocupadas, em geral, por } \\
\text { analistas que são muito bons tecnicamente e no } \\
\text { exercício de suas funções. Contudo, não } \\
\text { necessariamente os potenciais líderes possuem as } \\
\text { competências necessárias para liderar e gerir pessoas. }\end{array}$ \\
\hline O3 & D & R4 & $\begin{array}{l}\text { Os líderes não se empenham o suficiente para definir a } \\
\text { visão de futuro de forma clara e transmiti-la para os } \\
\text { funcionários, gerando dificuldade de entendimento, } \\
\text { por parte desses, em saber exatamente o que é } \\
\text { esperado pelos líderes em relação às suas atividades. }\end{array}$ \\
\hline O3 & D & R4 & \begin{tabular}{l} 
Existe falta de clareza de objetivos e prioridades. \\
\hline
\end{tabular}
\end{tabular}

A partir da análise do Quadro 17, é possível observar cinco semelhanças entre as principais dificuldades encontradas:

1. Competência técnica como fator principal, na maioria das vezes único, para as promoções (cinco citações, pelo menos uma por organização). Essa questão, na opinião dos respondentes, possibilita que muitos líderes sem as competências gerenciais necessárias - como a interpessoal - se qualifiquem para posições de liderança.

2. Falta de delegação dos trabalhos por parte dos líderes (três citações, uma por instituição).

3. Incapacidade do líder de motivar a equipe (três citações). Essa incapacidade, segundo a opinião de dois dos três colaboradores, reside na falta de competência gerencial por parte dos líderes, fato já apontado na primeira similaridade identificada.

4. Visão departamental ou 'feudal' por parte dos líderes (duas citações). Segundo essas opiniões, os líderes perdem a visão do todo, pois preocupam-se somente com seu departamento ou área funcional.

5. Falta de pró-atividade ou empenho, por parte dos líderes, na preparação da organização para o futuro (duas citações).

No Quadro 18, são apresentadas as soluções de melhorias apontadas pelos respondentes na dimensão Liderança. 
Quadro 18 - Soluções de melhorias na dimensão Liderança

\begin{tabular}{|c|c|c|c|}
\hline Organização & Área & Respondente & Descrição \\
\hline O1 & $\mathrm{E}$ & R1 & $\begin{array}{l}\text { Maior investimento em capacitação para a liderança } \\
\text { estratégica. }\end{array}$ \\
\hline $\mathrm{O} 1$ & $\mathrm{E}$ & R1 & $\begin{array}{l}\text { Seleção de líderes para cargos de confiança com base } \\
\text { em habilidades e atitudes gerenciais. }\end{array}$ \\
\hline $\mathrm{O} 1$ & $\mathrm{E}$ & R2 & $\begin{array}{l}\text { Maior investimento em capacitação para a liderança } \\
\text { estratégica. }\end{array}$ \\
\hline $\mathrm{O} 1$ & $\mathrm{E}$ & R2 & $\begin{array}{l}\text { Criação e aprimoramento dos mecanismos de } \\
\text { premiação individual. }\end{array}$ \\
\hline $\mathrm{O} 1$ & $\mathrm{D}$ & R3 & $\begin{array}{l}\text { Capacitação dos líderes no âmbito da delegação de } \\
\text { funções. }\end{array}$ \\
\hline $\mathrm{O} 1$ & $\mathrm{D}$ & R4 & $\begin{array}{l}\text { Maior comunicação entre as diretorias e suas } \\
\text { coordenações. }\end{array}$ \\
\hline $\mathrm{O} 2$ & $\mathrm{E}$ & R1 & Capacitação dos líderes no âmbito da visão estratégica. \\
\hline $\mathrm{O} 2$ & $\mathrm{E}$ & R2 & $\begin{array}{l}\text { Continuidade do programa de formação de líderes que } \\
\text { vem proporcionando resultados satisfatórios no âmbito } \\
\text { da organização, uma vez que o aprimoramento de } \\
\text { líderes é um processo lento de aprendizagem pela } \\
\text { experiência. }\end{array}$ \\
\hline $\mathrm{O} 2$ & $\mathrm{D}$ & R3 & $\begin{array}{l}\mathrm{O} \text { estímulo e a participação dos servidores em } \\
\text { atividades e decisões importantes. }\end{array}$ \\
\hline $\mathrm{O} 2$ & $\mathrm{D}$ & R3 & $\begin{array}{l}\text { Reconhecimento dos trabalhos bem executados, } \\
\text { independentemente de outros fatores }\end{array}$ \\
\hline $\mathrm{O} 2$ & $\mathrm{D}$ & R4 & $\begin{array}{l}\text { Recompensa dos servidores com competência técnica } \\
\text { com promoções ligadas ao assessoramento, deixando } \\
\text { que a motivação e o gerenciamento da equipe estejam } \\
\text { a cargo de profissionais com maior competência } \\
\text { gerencial. }\end{array}$ \\
\hline $\mathrm{O} 2$ & $\mathrm{D}$ & R4 & $\begin{array}{l}\text { Realização de capacitações para os líderes atuais da } \\
\text { organização. }\end{array}$ \\
\hline $\mathrm{O} 3$ & $\mathrm{E}$ & R1 & $\begin{array}{lllll}\text { Preparação e desenvolvimento } & \text { dos líderes da } \\
\text { organização. } & & & & \end{array}$ \\
\hline $\mathrm{O} 3$ & $\mathrm{E}$ & R2 & $\begin{array}{l}\text { Preparação e desenvolvimento dos líderes da } \\
\text { organização no âmbito da pró-atividade. }\end{array}$ \\
\hline $\mathrm{O} 3$ & $\mathrm{E}$ & R2 & $\begin{array}{l}\text { Maior delegação, por parte dos líderes, dos trabalhos } \\
\text { sob sua supervisão. }\end{array}$ \\
\hline
\end{tabular}


Quadro 18 - Soluções de melhorias na dimensão Liderança (continuação)

\begin{tabular}{|c|c|c|l|}
\hline Organização & \multicolumn{1}{c|}{ Área } & \multicolumn{1}{c|}{ Respondente } & \multicolumn{1}{c|}{ Descrição } \\
\hline O3 & D & R3 & $\begin{array}{l}\text { A organização deveria redefinir o plano de carreiras } \\
\text { para englobar o nível especialista e o nível gerencial. } \\
\text { Hoje, a organização prevê em seu plano apenas o nível } \\
\text { gerencial. }\end{array}$ \\
\hline O3 & D & R4 & $\begin{array}{l}\text { Maior empenho, por parte dos líderes, em definir a } \\
\text { visão de futuro de forma clara e transmiti-la aos } \\
\text { funcionários. }\end{array}$ \\
\hline O3 & D & R4 & $\begin{array}{l}\text { Maior monitoramento, por parte dos líderes, das } \\
\text { atividades que foram solicitadas, evitando } \\
\text { sobreposição excessiva de entregas e falta de } \\
\text { acompanhamento efetivo da evolução das atividades } \\
\text { que foram demandadas. }\end{array}$ \\
\hline
\end{tabular}

Pela análise do Quadro 18, é possível observar três semelhanças entre as soluções de melhorias apontadas pelos respondentes:

1. Investimento em capacitação para as lideranças organizacionais (oito citações, pelo menos duas por organização). Sobre esse fato, os colaboradores acreditam que os líderes devem ser melhor preparados para exercer funções gerenciais.

2. Seleção dos líderes com base em suas competências gerenciais (três citações, uma de cada organização). Nessa semelhança, dois dos três colaboradores que sugeriram essa forma de seleção, consideram que os funcionários com excelentes níveis técnicos devem ser alçados a posições de assessoramento.

3. Maior delegação, por parte dos líderes, das atividades sob responsabilidade deles (três citações, uma de cada organização).

\subsection{2.}

\section{Cultura e Valores}

Com base no $S M M M^{\mathrm{TM}}$ e na análise da Tabela 2, observa-se que as três organizações classificam-se como estruturadas e pró-ativas (com pontuação entre 2,5 e 3,49), conforme pode ser observado no Quadro 15. Esse nível de maturidade é 
o terceiro em uma escala de um a cinco, representando assim um nível mediano de desenvolvimento na dimensão Cultura e Valores.

Tabela 2 - Respostas dos questionários na dimensão Cultura e Valores

\begin{tabular}{|c|c|c|c|c|c|c|c|c|c|}
\hline & O1E & O1D & $\mathrm{O} 1 \mathrm{G}$ & $\mathrm{O} 2 \mathrm{E}$ & $\mathrm{O} 2 \mathrm{D}$ & $\mathrm{O} 2 \mathrm{G}$ & O3E & O3D & $\mathrm{O} 3 \mathrm{G}$ \\
\hline $\begin{array}{l}\text { A liderança } \text { aplica } \\
\text { corretamente os princípios e } \\
\text { práticas de gestão da } \\
\text { mudança. }\end{array}$ & 4,00 & 3,00 & 3,50 & 2,50 & 2,50 & 2,50 & 2,00 & 2,50 & 2,25 \\
\hline 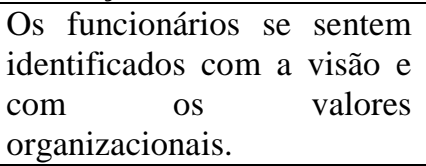 & 3,50 & 3,00 & 3,25 & 4,50 & 3,50 & 4,00 & 4,00 & 4,00 & 4,00 \\
\hline $\begin{array}{l}\text { Os funcionários participam } \\
\text { ativamente da construção da } \\
\text { cultura organizacional e das } \\
\text { formas de trabalho. }\end{array}$ & 3,50 & 2,50 & 3,00 & 3,50 & 3,00 & 3,25 & 3,00 & 4,00 & 3,50 \\
\hline $\begin{array}{l}\text { Os funcionários se } \\
\text { comunicam com confiança, } \\
\text { transparência e liberdade } \\
\text { para interagir com } \\
\text { franqueza, em oposição a } \\
\text { uma cultura de medo e de } \\
\text { negação. }\end{array}$ & 2,50 & 4,50 & 3,50 & 3,50 & 3,50 & 3,50 & 3,50 & 4,50 & 4,00 \\
\hline $\begin{array}{l}\text { Os funcionários possuem } \\
\text { flexibilidade e vontade de } \\
\text { mudar para alinhar a novas } \\
\text { prioridades estratégicas. }\end{array}$ & 4,00 & 2,50 & 3,25 & 3,50 & 2,00 & 2,75 & 2,00 & 3,50 & 2,75 \\
\hline $\begin{array}{l}\text { Os funcionários têm } \\
\text { consciência dos valores e } \\
\text { políticas } \\
\text { aderindo a eles de forma } \\
\text { consistente. }\end{array}$ & 3,50 & 2,00 & 2,75 & 3,50 & 3,50 & 3,50 & 4,00 & 4,00 & 4,00 \\
\hline Nível de Maturidade & 3,50 & 2,92 & 3,21 & 3,50 & 3,00 & 3,25 & 3,08 & 3,75 & 3,42 \\
\hline
\end{tabular}

No Quadro 19, são apresentadas as principais dificuldades apontadas pelos respondentes na dimensão Cultura e Valores.

Quadro 19 - Principais dificuldades na dimensão Cultura e Valores

\begin{tabular}{|c|c|c|c|}
\hline Organização & Área & Respondente & Descrição \\
\hline $\mathrm{O} 1$ & $\mathrm{E}$ & R1 & $\begin{array}{l}\text { Existe resistência por parte dos servidores em relação à } \\
\text { mudança, sob o pretexto de que "em time que tá } \\
\text { ganhando não se mexe". }\end{array}$ \\
\hline O1 & $\mathrm{E}$ & $\mathrm{R} 2$ & $\begin{array}{l}\text { Falta de preocupação da alta administração com a cultura } \\
\text { organizacional. Os valores ressaltados são apenas os que } \\
\text { pertencem à área técnica. }\end{array}$ \\
\hline
\end{tabular}


Quadro 19 - Principais dificuldades na dimensão Cultura e Valores (continuação)

\section{\begin{tabular}{ll|ll} 
Organização Área & Respondente Descrição
\end{tabular}}

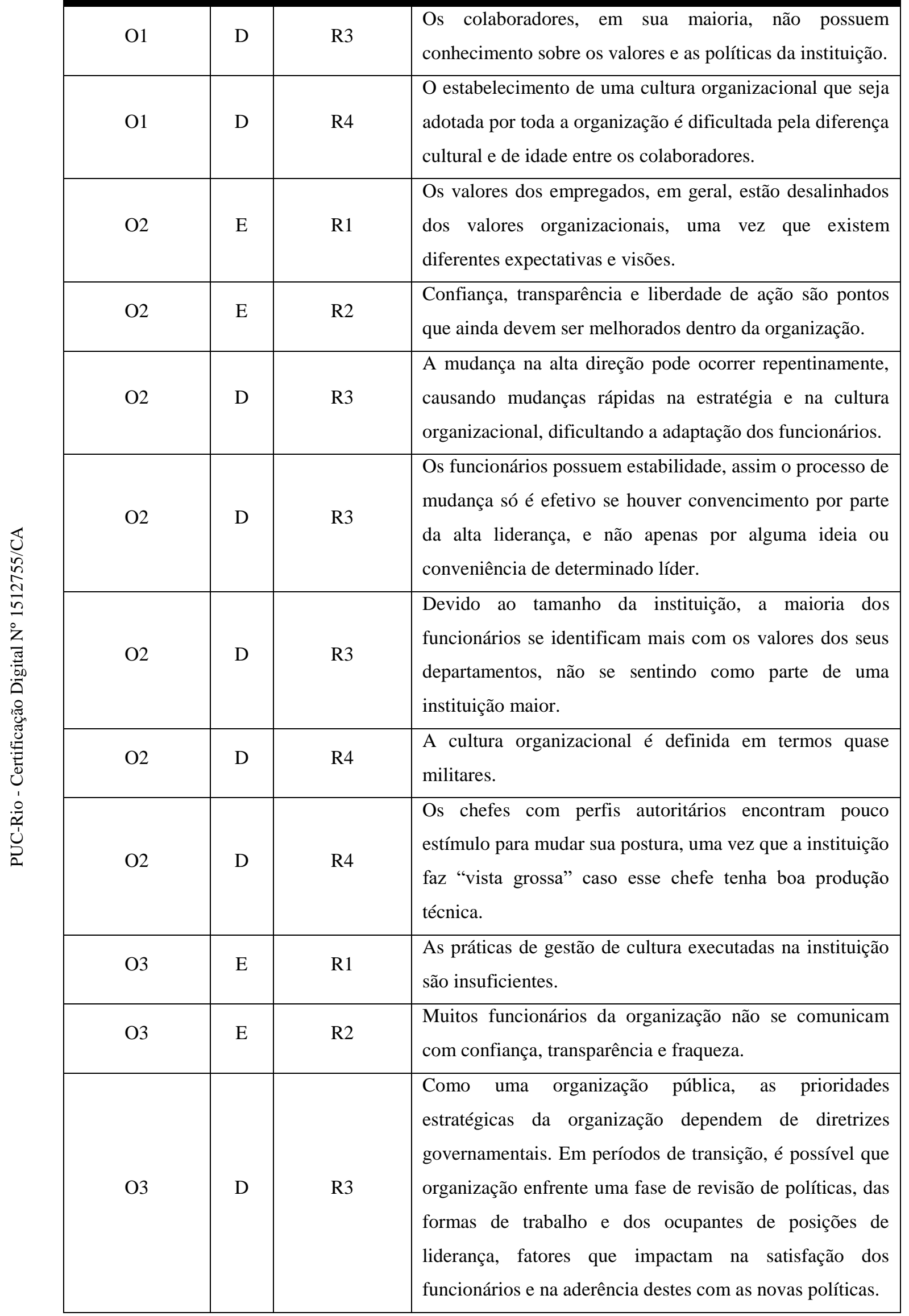


Com base na análise do Quadro 19, é possível observar quatro semelhanças entre as principais dificuldades encontradas:

1. Diferença cultural entre os funcionários (três citações). Essas opiniões indicaram fatores como tamanho da instituição, visão departamental, diferença etária e falta de uma visão global por parte da organização como maximizadores das diferenças culturais dentro de suas instituições.

2. Resistência a mudanças por parte dos funcionários (duas citações). Tal resistência pode dever-se à satisfação com a situação atual da organização ou à estabilidade, que permite, de forma indireta, aos colaboradores concordarem com a mudança de forma efetiva apenas se forem convencidos pela liderança.

3. Troca repentina de membros da alta direção, podendo impactar na satisfação ou na adaptação dos funcionários à cultura organizacional (duas citações).

4. Valores como confiança, transparência e liberdade de ação ainda não são utilizados, da forma devida, na organização (duas citações).

No Quadro 20, são apresentadas as soluções de melhorias apontadas pelos respondentes na dimensão Cultura e Valores.

Quadro 20 - Soluções de melhorias na dimensão Cultura e Valores

\begin{tabular}{|c|c|c|l|}
\hline Organização & Área & \multicolumn{1}{|c|}{ Respondente } & \multicolumn{1}{|c|}{ Descrição } \\
\hline O1 & E & R1 & $\begin{array}{l}\text { Disseminar as boas práticas no âmbito da gestão da mudança } \\
\text { e valorizar os servidores que conseguiram implementar } \\
\text { mudanças na instituição. }\end{array}$ \\
\hline O1 & E & R2 & $\begin{array}{l}\text { Capacitação e conscientização da alta administração sobre a } \\
\text { importância da cultura organizacional. }\end{array}$ \\
\hline O1 & D & R3 & Aumentar e aprimorar a comunicação interna. \\
\hline O1 & D & R4 & $\begin{array}{l}\text { Aumentar e aprimorar a comunicação interna no âmbito da } \\
\text { cultura, dos valores organizacionais e da complementaridade } \\
\text { entre gerações. }\end{array}$ \\
\hline O2 & E & R1 & $\begin{array}{l}\text { Disponibilização de um canal de interação entre os } \\
\text { servidores e a organização. }\end{array}$ \\
\hline O2 & E & R1 & $\begin{array}{l}\text { Aprimorar a comunicação interna para que essa seja } \\
\text { tempestiva no que concerne as informações de grande } \\
\text { impacto no corpo funcional. }\end{array}$ \\
\hline
\end{tabular}


Quadro 20 - Soluções de melhorias na dimensão Cultura e Valores (continuação)

\begin{tabular}{|c|c|c|c|}
\hline Organização & Área & Respondente & Descrição \\
\hline $\mathrm{O} 2$ & $\mathrm{E}$ & $\mathrm{R} 1$ & $\begin{array}{l}\text { Realização de pesquisa de satisfação com os servidores } \\
\text { da instituição. }\end{array}$ \\
\hline $\mathrm{O} 2$ & $\mathrm{E}$ & $\mathrm{R} 2$ & $\begin{array}{l}\text { Os valores de transparência e integração devem ser } \\
\text { priorizados nas ações de melhoria do clima } \\
\text { organizacional, devendo, também, ser internalizados } \\
\text { começando pelo corpo gerencial até os demais } \\
\text { funcionários. }\end{array}$ \\
\hline $\mathrm{O} 2$ & $\mathrm{D}$ & $\mathrm{R} 3$ & $\begin{array}{l}\text { Mostrar para os funcionários, de forma enfática, a } \\
\text { importância da instituição e de suas funções para a } \\
\text { sociedade. }\end{array}$ \\
\hline $\mathrm{O} 2$ & $\mathrm{D}$ & $\mathrm{R} 4$ & $\begin{array}{l}\text { Manter atenção constante para que desvios aos valores } \\
\text { declarados sejam identificados e eliminados, de forma } \\
\text { a garantir aos servidores o compromisso da instituição } \\
\text { com esses valores. }\end{array}$ \\
\hline $\mathrm{O} 3$ & $\mathrm{E}$ & $\mathrm{R} 1$ & $\begin{array}{l}\text { Entender quais são as dimensões culturais que podem } \\
\text { ser gerenciadas e quais requerem maior atenção frente } \\
\text { aos desafios atuais e futuros da organização. }\end{array}$ \\
\hline O3 & $\mathrm{E}$ & $\mathrm{R} 2$ & Aumentar os investimentos em comunicação interna. \\
\hline $\mathrm{O} 3$ & $\mathrm{D}$ & $\mathrm{R} 3$ & $\begin{array}{l}\text { A organização deveria aprimorar as práticas de gestão } \\
\text { da mudança. }\end{array}$ \\
\hline
\end{tabular}

A partir da análise do Quadro 20, é possível observar apenas uma, porém importante, semelhança, entre as soluções de melhorias apontadas pelos respondentes:

1. Aprimoramento e desenvolvimento de ações de comunicação interna com o objetivo de envolver e informar os funcionários sobre as ações, no âmbito da cultura, valores e outros temas relevantes, dentro de suas respectivas organizações (seis citações, sendo duas por instituição).

\subsection{3.}

\section{Pensamento Estratégico e Planejamento}

Com base no $S M M M^{\mathrm{TM}}$ e na análise da Tabela 3, observa-se que duas organizações (O1 e O2) classificam-se como estruturadas e pró-ativas (com pontuação entre 2,5 e 3,49), enquanto uma organização (O3) classifica-se como gerenciada e focada (com pontuação entre 3,5 e 4,49), conforme pode ser 
observado no Quadro 15. Os níveis de maturidade supracitados representam o terceiro e quatro estágio de maturidade, respectivamente. O nível três representa que as instituições possuem desempenho mediano na dimensão Pensamento Estratégico e Planejamento, enquanto o nível quatro demonstra que a organização possui bom desempenho nessa dimensão. Sobre a Tabela 3, é interessante frisar, ainda, que ambos os respondentes das demais áreas da organização 2 não souberam informar se a organização considera ou não estratégias e cenários alternativos no âmbito do planejamento.

Tabela 3 - Respostas dos questionários na dimensão Pensamento Estratégico e Planejamento

\begin{tabular}{|c|c|c|c|c|c|c|c|c|c|}
\hline & O1E & O1D & $\mathrm{O} 1 \mathrm{G}$ & $\mathrm{O} 2 \mathrm{E}$ & $\mathrm{O} 2 \mathrm{D}$ & $\mathrm{O} 2 \mathrm{G}$ & O3E & O3D & $\mathrm{O} 3 \mathrm{G}$ \\
\hline $\begin{array}{l}\text { A organização possui a } \\
\text { habilidade de usar definições } \\
\text { consistentes de planejamento } \\
\text { e entender suas distinções. }\end{array}$ & 4,00 & 4,00 & 4,00 & 4,00 & 4,00 & 4,00 & 4,50 & 4,00 & 4,25 \\
\hline $\begin{array}{l}\text { A organização consegue } \\
\text { entender a diferença entre } \\
\text { planejamento de projetos e } \\
\text { planejamento estratégico. }\end{array}$ & 4,00 & 3,00 & 3,50 & 4,00 & 4,50 & 4,25 & 5,00 & 5,00 & 5,00 \\
\hline $\begin{array}{l}\text { A organização é capaz de } \\
\text { discutir e descrever itens em } \\
\text { planos com a 'dimensão } \\
\text { estratégica' apropriada. }\end{array}$ & 3,50 & 3,00 & 3,25 & 3,00 & 4,00 & 3,50 & 4,50 & 4,50 & 4,50 \\
\hline $\begin{array}{lll}\text { A organização } & \text { possui } \\
\text { consciência dos } & \text { efeitos } \\
\text { dinâmicos do sistema. } & \end{array}$ & 3,00 & 3,00 & 3,00 & 2,00 & 3,00 & 2,50 & 2,50 & 4,00 & 3,25 \\
\hline $\begin{array}{l}\text { A organização é aberta a } \\
\text { novas ideias e encoraja a } \\
\text { criatividade e inovação entre } \\
\text { os funcionários. }\end{array}$ & 3,50 & 3,50 & 3,50 & 3,00 & 2,00 & 2,50 & 3,00 & 4,00 & 3,50 \\
\hline $\begin{array}{l}\text { A organização possui um } \\
\text { processo de planejamento } \\
\text { aberto aos funcionários de } \\
\text { vários níveis e funções. }\end{array}$ & 3,50 & 2,50 & 3,00 & 4,00 & 2,00 & 3,00 & 3,00 & 3,50 & 3,25 \\
\hline 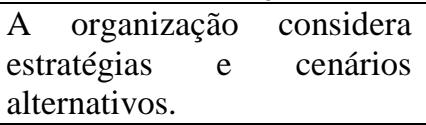 & 2,50 & 3,00 & 2,75 & 3,00 & - & 3,00 & 4,50 & 2,50 & 3,50 \\
\hline $\begin{array}{l}\text { Existe ligação entre o } \\
\text { planejamento estratégico e o } \\
\text { orçamento. }\end{array}$ & 3,00 & 3,00 & 3,00 & 3,00 & 3,00 & 3,00 & 3,50 & 3,50 & 3,50 \\
\hline $\begin{array}{l}\text { Existe a habilidade } \text { de } \\
\text { escrever e falar com clareza } \\
\text { e simplicidade na } \\
\text { organização. }\end{array}$ & 3,50 & 4,50 & 4,00 & 3,00 & 3,50 & 3,25 & 3,00 & 4,00 & 3,50 \\
\hline Nível de Maturidade & 3,39 & 3,28 & 3,33 & 3,22 & 3,25 & 3,22 & 3,72 & 3,89 & 3,81 \\
\hline
\end{tabular}

No Quadro 21, foram descritas as principais dificuldades apontadas pelos respondentes na dimensão Pensamento Estratégico e Planejamento. 
Quadro 21 - Principais dificuldades na dimensão Pensamento Estratégico e Planejamento

\section{\begin{tabular}{ll|ll} 
Organização Área & Respondente Descrição
\end{tabular}}

\begin{tabular}{|c|c|c|c|}
\hline O1 & $\mathrm{E}$ & $\mathrm{R} 1$ & $\begin{array}{l}\text { Pelo tamanho da instituição, é difícil envolver todos os } \\
\text { funcionários no processo de planejamento estratégico. A } \\
\text { unidade organizacional responsável por esse planejamento } \\
\text { envolve os líderes até o } 3^{\circ} \text { nível de hierarquia, cabendo a } \\
\text { eles o repasse das orientações para condução do processo } \\
\text { no âmbito de suas equipes. Nesse ponto, muitas vezes, há } \\
\text { ruptura da cadeia de envolvimento de pessoas no } \\
\text { planejamento estratégico. }\end{array}$ \\
\hline O1 & $\mathrm{E}$ & $\mathrm{R} 2$ & $\begin{array}{l}\text { A atividade de planejamento não é valorizada dentro da } \\
\text { instituição. }\end{array}$ \\
\hline O1 & $\mathrm{E}$ & $\mathrm{R} 2$ & $\begin{array}{l}\text { Falta de conhecimento por parte da alta administração no } \\
\text { que diz respeito a pensamento estratégico e planejamento. }\end{array}$ \\
\hline O1 & $\mathrm{D}$ & R3 & $\begin{array}{l}\text { Nem todos os funcionários conhecem o planejamento } \\
\text { estratégico da instituição. }\end{array}$ \\
\hline O1 & $\mathrm{D}$ & R4 & $\begin{array}{l}\text { O planejamento estratégico institucional se assemelha } \\
\text { mais, em muitos sentidos, a um portfólio de resultados. }\end{array}$ \\
\hline $\mathrm{O} 2$ & $\mathrm{E}$ & R1 & A organização possui uma visão imediatista. \\
\hline $\mathrm{O} 2$ & $\mathrm{E}$ & $\mathrm{R} 1$ & $\begin{array}{l}\text { Os controles organizacionais são muito rígidos no que diz } \\
\text { respeito ao cumprimento de normativos. }\end{array}$ \\
\hline $\mathrm{O} 2$ & $\mathrm{E}$ & $\mathrm{R} 1$ & $\begin{array}{l}\text { A correção de rumos das ações estratégicas ocorre de } \\
\text { forma personalista, sem a devida reflexão sobre o que foi } \\
\text { estabelecido no planejamento inicial. }\end{array}$ \\
\hline $\mathrm{O} 2$ & $\mathrm{E}$ & R2 & Pensamento exclusivo em tarefas cotidianas. \\
\hline $\mathrm{O} 2$ & $\mathrm{D}$ & R3 & $\begin{array}{l}\text { Falta de encorajamento, por parte da organização, na } \\
\text { participação dos funcionários no desenvolvimento do } \\
\text { planejamento estratégico. }\end{array}$ \\
\hline $\mathrm{O} 2$ & $\mathrm{D}$ & R3 & $\begin{array}{l}\text { Os funcionários focam-se em projetos específicos, não } \\
\text { possuindo a visão do todo, nem pensando como a } \\
\text { organização deve se aprimorar no longo prazo. }\end{array}$ \\
\hline $\mathrm{O} 2$ & $\mathrm{D}$ & $\mathrm{R} 4$ & $\begin{array}{l}\text { No âmbito administrativo, a organização possui } \\
\text { características conservadoras, muito comum em } \\
\text { instituições públicas, o que limita ações abertas, criativas e } \\
\text { inovadoras. }\end{array}$ \\
\hline $\mathrm{O} 3$ & $\mathrm{E}$ & $\mathrm{R} 1$ & $\begin{array}{l}\text { A organização proporciona pouca abertura ao erro, por } \\
\text { conseguinte, os funcionários da instituição possuem pouca } \\
\text { propensão ao risco. }\end{array}$ \\
\hline
\end{tabular}


Quadro 21 - Principais dificuldades na dimensão Pensamento Estratégico e Planejamento (continuação)

\begin{tabular}{|c|c|c|l|}
\hline Organização & \multicolumn{2}{|c|}{ Área } & \multicolumn{1}{c|}{ Respondeção } \\
\hline O3 & E & R2 & $\begin{array}{l}\text { O processo de planejamento da instituição não é } \\
\text { sempre aberto aos funcionários de vários níveis e } \\
\text { funções. }\end{array}$ \\
\hline O3 & D & R3 & $\begin{array}{l}\text { O planejamento estratégico considera superficialmente } \\
\text { cenários alternativos e restrições no orçamento, fatores } \\
\text { que poderiam ser melhor explorados. }\end{array}$ \\
\hline O3 & D & R4 & $\begin{array}{l}\text { O processo de pensamento estratégico e planejamento } \\
\text { não envolve a todos na organização. }\end{array}$ \\
\hline
\end{tabular}

A partir da análise do Quadro 21, é possível observar cinco semelhanças entre as principais dificuldades encontradas:

1. Falta de conhecimento sobre planejamento (três citações, todas da mesma instituição). Essa semelhança uniu tanto o desconhecimento do planejamento estratégico da instituição por parte dos funcionários, quanto o desconhecimento de conceitos ligados à atividade de planejamento por parte dos funcionários e da alta direção.

2. Foco em questões de curto prazo por parte da organização (três citações, todas da mesma instituição).

3. Limitações à inovação (três citações). Fatores como pouca abertura ao erro, características conservadoras e controles organizacionais muito rígidos são fatores citados pelos colaboradores no que concerne à essa similaridade.

4. Falta de participação do corpo funcional no processo de planejamento estratégico (três citações).

5. Falta de valorização da atividade de planejamento dentro da organização (duas citações). Nessa semelhança, os funcionários e líderes, podem até conhecer o processo, porém não dão a devida importância ao que foi planejado inicialmente.

No Quadro 22, são apresentadas as soluções de melhorias apontadas pelos respondentes na dimensão Pensamento Estratégico e Planejamento. 
Quadro 22 - Soluções de melhorias na dimensão Pensamento Estratégico e Planejamento

\begin{tabular}{|c|c|c|c|}
\hline Organização & Área & Respondente & Descrição \\
\hline O1 & $\mathrm{E}$ & $\mathrm{R} 1$ & $\begin{array}{l}\text { Reforçar o papel do gestor como disseminador do } \\
\text { pensamento estratégico na instituição. }\end{array}$ \\
\hline $\mathrm{O} 1$ & $\mathrm{E}$ & $\mathrm{R} 2$ & $\begin{array}{l}\text { Conscientizar a alta administração sobre a importância } \\
\text { do pensamento estratégico e do planejamento. }\end{array}$ \\
\hline O1 & D & R3 & $\begin{array}{l}\text { Divulgação do planejamento estratégico para todos os } \\
\text { níveis organizacionais. }\end{array}$ \\
\hline O1 & $\mathrm{D}$ & $\mathrm{R} 4$ & $\begin{array}{l}\text { Difundir na instituição } \mathrm{o} \text { real significado do } \\
\text { planejamento estratégico. }\end{array}$ \\
\hline $\mathrm{O} 2$ & $\mathrm{E}$ & $\mathrm{R} 1$ & $\begin{array}{l}\text { Criação de um comitê que se reúna periodicamente } \\
\text { com o intuito de alinhar e convergir esforços para a } \\
\text { avaliação e o cumprimento da estratégia da } \\
\text { organização, bem como dos resultados alcançados. }\end{array}$ \\
\hline $\mathrm{O} 2$ & $\mathrm{E}$ & $\mathrm{R} 1$ & $\begin{array}{l}\text { Desenvolver trabalhos de comunicação interna, } \\
\text { buscando o envolvimento de todos os colaboradores na } \\
\text { definição da estratégia. }\end{array}$ \\
\hline $\mathrm{O} 2$ & $\mathrm{E}$ & $\mathrm{R} 2$ & $\begin{array}{l}\text { Ampliar a participação, de todos os níveis } \\
\text { organizacionais, em cursos, seminários e congressos } \\
\text { que possuam foco em planejamento estratégico, bem } \\
\text { como desenvolver cursos internos pela universidade } \\
\text { corporativa que disseminem permanentemente o } \\
\text { pensamento estratégico nas lideranças e servidores. }\end{array}$ \\
\hline $\mathrm{O} 2$ & $\mathrm{D}$ & R3 & $\begin{array}{l}\text { Encorajamento, por parte da alta direção, a } \\
\text { participação dos funcionários no processo de } \\
\text { planejamento estratégico. }\end{array}$ \\
\hline $\mathrm{O} 2$ & $\mathrm{D}$ & $\mathrm{R} 4$ & $\begin{array}{l}\text { Muitos funcionários estão se aposentando. Tal fato } \\
\text { pode fazer com que essa dimensão se desenvolva } \\
\text { melhor dentro da organização. }\end{array}$ \\
\hline $\mathrm{O} 3$ & $\mathrm{E}$ & $\mathrm{R} 1$ & $\begin{array}{l}\text { Desenvolvimento de um processo estruturado de } \\
\text { inovação organizacional. }\end{array}$ \\
\hline $\mathrm{O} 3$ & $\mathrm{E}$ & $\mathrm{R} 2$ & $\begin{array}{l}\text { Maior participação do corpo funcional no processo de } \\
\text { planejamento. }\end{array}$ \\
\hline $\mathrm{O} 3$ & $\mathrm{D}$ & $\mathrm{R} 3$ & $\begin{array}{l}\text { Considerar de forma mais consistente, no processo de } \\
\text { planejamento, cenários pessimistas para a organização } \\
\text { de forma que essa possa se posicionar e reconhecer seu } \\
\text { papel claramente. }\end{array}$ \\
\hline $\mathrm{O} 3$ & D & $\mathrm{R} 4$ & $\begin{array}{l}\text { O processo de planejamento estratégico deveria ser } \\
\text { feito com maior participação de funcionários de } \\
\text { diferentes níveis. }\end{array}$ \\
\hline
\end{tabular}


A partir da análise do Quadro 22, é possível observar duas semelhanças entre as soluções de melhorias apontadas pelos respondentes:

1. Desenvolvimento de ações ligadas à comunicação interna (quatro citações, três da mesma instituição), como disseminação do planejamento estratégico para todos os níveis organizacionais, reforço do papel do gestor como disseminador do pensamento estratégico na instituição e difusão, por parte da organização, do significado correto de planejamento estratégico.

2. Maior participação, por parte do corpo funcional, nas atividades ligadas ao pensamento estratégico e planejamento (quatro citações).

\subsection{4.}

\section{Alinhamento}

Com base no $S M M M^{\mathrm{TM}}$ e na análise da Tabela 4, observa-se que duas organizações (O1 e O2) classificam-se como reativas (com pontuação entre 1,5 e $2,49)$, enquanto uma organização (O3) classifica-se como gerenciada e focada (com pontuação entre 3,5 e 4,49), conforme pode ser observado no Quadro 15. Os níveis de maturidade supracitados representam o segundo e quatro estágio de maturidade, respectivamente. O nível dois é o segundo em uma escala de um a cinco, representando que as organizações possuem desempenho ruim no desenvolvimento desta dimensão, enquanto o nível quatro demonstra que a organização possui bom desempenho na dimensão Alinhamento.

Tabela 4 - Respostas dos questionários na dimensão Alinhamento

\begin{tabular}{|l|l|l|l|l|l|l|l|l|l|l|l|}
\hline & O1E & \multicolumn{1}{l}{ O1D } & \multicolumn{1}{l}{ O1G } & \multicolumn{1}{l}{ O2E } & \multicolumn{2}{l}{ O2D } & O2G & O3E & O3D & O3G \\
\hline $\begin{array}{l}\text { Os funcionários de todos os } \\
\text { níveis da organização são } \\
\text { motivados por uma visão e } \\
\text { pela estratégia comuns. }\end{array}$ & 2,50 & 2,00 & 2,25 & 2,50 & 2,50 & 2,50 & 3,50 & 4,50 & 4,00 \\
\hline $\begin{array}{l}\text { Os funcionários entendem } \\
\text { que dar suporte à estratégia é } \\
\text { sua função. }\end{array}$ & 2,00 & 2,00 & 2,00 & 2,00 & 2,50 & 2,25 & 2,50 & 4,50 & 3,50 \\
\hline $\begin{array}{l}\text { Os funcionários são auto- } \\
\text { motivados, não atuando } \\
\text { apenas pela obediência as } \\
\text { normas. }\end{array}$ & 2,00 & 2,00 & 2,00 & 2,50 & 2,50 & 2,50 & 3,50 & 4,00 & 3,75 \\
\hline$\quad$ Nível de Maturidade & 2,17 & 2,00 & 2,09 & 2,33 & 2,50 & 2,42 & 3,17 & 4,33 & 3,75 \\
\hline
\end{tabular}


No Quadro 23, são apresentadas as principais dificuldades apontadas pelos respondentes na dimensão Alinhamento.

Quadro 23 - Principais dificuldades na dimensão Alinhamento

\begin{tabular}{|c|c|c|c|}
\hline Organização & Área & Respondente & Descrição \\
\hline $\mathrm{O} 1$ & $\mathrm{E}$ & R1 & $\begin{array}{l}\text { Os servidores envolvem-se em atividades rotineiras ou } \\
\text { operacionais e não percebem a ligação entre essas } \\
\text { atividades e a estratégia. }\end{array}$ \\
\hline $\mathrm{O} 1$ & E & R1 & $\begin{array}{l}\text { Há um grande número de servidores desmotivados, } \\
\text { trabalhando somente o mínimo necessário e não } \\
\text { aceitando assumir grandes desafios. }\end{array}$ \\
\hline $\mathrm{O} 1$ & E & R2 & $\begin{array}{l}\text { Falta de disseminação e comunicação da visão e da } \\
\text { estratégia organizacional. }\end{array}$ \\
\hline $\mathrm{O} 1$ & E & R2 & $\begin{array}{l}\text { Falta de definição clara sobre quais são as estratégias } \\
\text { da organização. }\end{array}$ \\
\hline $\mathrm{O} 1$ & D & R3 & $\begin{array}{l}\text { Não existe alinhamento entre o quadro funcional e a } \\
\text { estratégia organizacional. }\end{array}$ \\
\hline $\mathrm{O} 1$ & D & R4 & $\begin{array}{l}\text { Os funcionários possuem baixa motivação para } \\
\text { trabalhar e melhorar a organização. }\end{array}$ \\
\hline $\mathrm{O} 2$ & E & R1 & $\begin{array}{l}\text { Cada funcionário possui sua própria visão da } \\
\text { organização. }\end{array}$ \\
\hline $\mathrm{O} 2$ & E & R1 & $\begin{array}{l}\text { Não existe alinhamento das ações estratégicas entre as } \\
\text { lideranças e os subordinados. }\end{array}$ \\
\hline $\mathrm{O} 2$ & E & R1 & $\begin{array}{l}\text { Os servidores não são motivados para buscar conhecer } \\
\text { a dimensão estratégica da organização. }\end{array}$ \\
\hline $\mathrm{O} 2$ & D & R3 & $\begin{array}{l}\text { Devido ao tamanho e a estrutura hierárquica da } \\
\text { organização, quanto menor o nível do funcionário, } \\
\text { menos ele é motivado pela visão comum. }\end{array}$ \\
\hline $\mathrm{O} 2$ & D & R3 & $\begin{array}{l}\text { Os funcionários entram na organização motivados e } \\
\text { acabam perdendo a motivação com o tempo. }\end{array}$ \\
\hline $\mathrm{O} 2$ & D & R4 & $\begin{array}{l}\text { As normas legais e infralegais definem o que pode ou } \\
\text { não ser feito na organização. }\end{array}$ \\
\hline $\mathrm{O} 3$ & E & R1 & $\begin{array}{l}\text { Falta de alinhamento das atividades rotineiras (táticas } \\
\text { ou operacionais) com à estratégia. }\end{array}$ \\
\hline $\mathrm{O} 3$ & E & R2 & $\begin{array}{l}\text { Muitos funcionários atuam somente por obediência as } \\
\text { regras, não sendo auto-motivados. }\end{array}$ \\
\hline
\end{tabular}

A partir da análise do Quadro 23, é possível observar duas semelhanças entre as principais dificuldades encontradas: 
1. Falta de motivação (cinco citações, pelo menos uma por organização), gerando descompromisso das pessoas e dos recursos com estratégia organizacional.

2. Falta de disseminação e comunicação da estratégia para os funcionários da organização (quatro citações).

No Quadro 24, são apresentadas as soluções de melhorias apontadas pelos respondentes na dimensão Alinhamento.

Quadro 24 - Soluções de melhorias na dimensão Alinhamento

\begin{tabular}{|c|c|c|c|}
\hline Organização & Área & Respondente & Descrição \\
\hline $\mathrm{O} 1$ & E & R1 & $\begin{array}{l}\text { Premiação por mérito e abertura de canais para } \\
\text { compartilhar boas ideias. }\end{array}$ \\
\hline $\mathrm{O} 1$ & E & R2 & $\begin{array}{l}\text { Definição clara da estratégia e disseminação, por meio } \\
\text { de uma comunicação organizacional eficaz, do papel } \\
\text { de cada funcionário dentro do contexto estratégico. }\end{array}$ \\
\hline $\mathrm{O} 1$ & D & R3 & 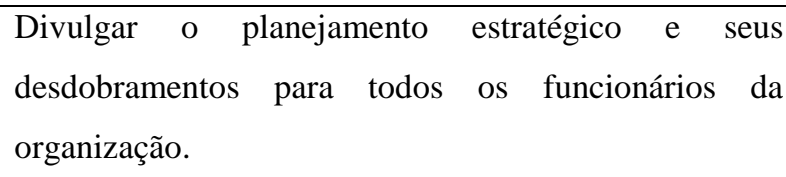 \\
\hline $\mathrm{O} 1$ & D & R4 & $\begin{array}{l}\text { Maior envolvimento dos servidores na elaboração de } \\
\text { propostas de ações estratégicas e no controle dos } \\
\text { resultados estratégicos. }\end{array}$ \\
\hline $\mathrm{O} 2$ & E & R1 & $\begin{array}{l}\text { A liderança deve reservar encontros periódicos de } \\
\text { alinhamento da estratégia com os subordinados, } \\
\text { mostrando a importância da estratégia, abrindo espaço } \\
\text { para proposições e participação. }\end{array}$ \\
\hline $\mathrm{O} 2$ & $\mathrm{E}$ & $\mathrm{R} 2$ & $\begin{array}{l}\text { Capacitação dos líderes e formas de avaliação de } \\
\text { desempenho levando em consideração os critérios do } \\
\text { alinhamento da estratégia nessa avaliação. }\end{array}$ \\
\hline $\mathrm{O} 2$ & E & R3 & $\begin{array}{l}\text { Maior comunicação direta entre pessoas do alto } \\
\text { escalão com funcionários de níveis mais baixos, uma } \\
\text { vez que eles possuem uma visão estratégica mais } \\
\text { ampla em função do cargo que ocupam. }\end{array}$ \\
\hline $\mathrm{O} 2$ & D & R3 & $\begin{array}{l}\text { Recompensar os funcionários com bons trabalhos } \\
\text { prestados, independente do seu nível hierárquico. }\end{array}$ \\
\hline $\mathrm{O} 3$ & E & R1 & $\begin{array}{l}\text { Complementar a gestão estratégica com a gestão por } \\
\text { processos. }\end{array}$ \\
\hline $\mathrm{O} 3$ & E & R2 & $\begin{array}{l}\text { Adotar medidas para valorização e engajamento dos } \\
\text { funcionários. }\end{array}$ \\
\hline
\end{tabular}


A partir da análise do Quadro 24, é possível observar três semelhanças entre as soluções de melhorias apontadas pelos respondentes:

1. Maior participação e envolvimento por parte dos funcionários no processo de gestão estratégica (três citações de diferentes organizações).

2. Maior disseminação e comunicação da estratégia organizacional para os funcionários (três citações).

3. Implementação de premiações por mérito (três citações de diferentes organizações). Para esses respondentes, as organizações devem adotar medidas de valorização e recompensa para os funcionários que tiverem bom desempenho e forem alinhados com a estratégia organizacional.

\subsection{5. \\ Mensuração de Desempenho}

Baseado no $S M M M^{\mathrm{TM}}$ e na análise da Tabela 5, observa-se que uma organização $(\mathrm{O} 1)$ classifica-se como estruturada e pró-ativa (com pontuação entre 2,5 e 3,49), enquanto duas organizações (O2 e O3) classificam-se como gerenciadas e focadas (com pontuação entre 3,49 e 4,49), conforme pode ser observado no Quadro 15. Os níveis de maturidade supracitados representam o terceiro e quatro estágio de maturidade, respectivamente. O nível três representa que a organização possui desempenho mediano na dimensão Mensuração de Desempenho, enquanto o nível quatro demonstra que as instituições possuem bom desempenho nessa dimensão.

Tabela 5 - Respostas dos questionários na dimensão Mensuração de Desempenho

\begin{tabular}{|l|l|l|l|l|l|l|l|l|l|}
\hline \multicolumn{1}{|c|}{ O1E } & O1D & O1G & O2E & O2D & O2G & O3E & O3D & O3G \\
\hline $\begin{array}{l}\text { Os indicadores são } \\
\text { derivados e estão alinhados } \\
\text { com a estratégia, não } \\
\text { estando somente ligados à } \\
\text { ótica operacional. }\end{array}$ & 2,00 & 3,00 & 2,50 & 2,00 & 4,50 & 3,25 & 4,50 & 3,00 & 3,75 \\
\hline $\begin{array}{l}\text { Os indicadores estão focados } \\
\text { nos produtos e em } \\
\text { resultados, não somente em } \\
\text { gastos monetários, tarefas } \\
\text { cumpridas ou produção } \\
\text { entregue. }\end{array}$ & 2,00 & 4,00 & 3,00 & 3,00 & 4,50 & 3,75 & 4,50 & 3,00 & 3,75 \\
\hline
\end{tabular}


Tabela 5 - Respostas dos questionários na dimensão Mensuração de Desempenho (continuação)

\begin{tabular}{|c|c|c|c|c|c|c|c|c|c|}
\hline & O1E & O1D & O1G & $\mathrm{O} 2 \mathrm{E}$ & O2D & $\mathrm{O} 2 \mathrm{G}$ & O3E & O3D & $\mathrm{O} 3 \mathrm{G}$ \\
\hline $\begin{array}{l}\text { Os indicadores utilizam } \\
\text { relações, tamanho de } \\
\text { amostras e } r \text { outras } \\
\text { características de forma } \\
\text { adequada, visando ser mais } \\
\text { significativos. }\end{array}$ & 2,00 & 2,00 & 2,00 & 4,00 & 4,00 & 4,00 & 4,00 & 2,00 & 3,00 \\
\hline $\begin{array}{l}\text { Os indicadores são } \\
\text { mensurados e reportados em } \\
\text { tempo hábil para auxiliar a } \\
\text { tomada de decisão. }\end{array}$ & 2,00 & 2,00 & 2,00 & 3,00 & 4,00 & 3,50 & 5,00 & 2,00 & 3,50 \\
\hline $\begin{array}{l}\text { Não somente o desempenho } \\
\text { individual, mas também os } \\
\text { desempenhos da equipe e da } \\
\text { organização } \\
\text { monitorados. }\end{array}$ & 4,00 & 4,00 & 4,00 & 3,50 & 4,50 & 4,00 & 4,50 & 3,00 & 3,75 \\
\hline $\begin{array}{l}\text { Um sistema de indicadores } \\
\text { balanceado que englobe } \\
\text { diferentes dimensões } \\
\text { incluindo não somente dados } \\
\text { financeiros, mas também } \\
\text { satisfação do consumidor, } \\
\text { desempenho dos processos } \\
\text { internos e capacidades da } \\
\text { organização é utilizado. }\end{array}$ & 3,00 & 2,50 & 2,75 & 2,00 & 4,00 & 3,00 & 5,00 & 2,00 & 3,50 \\
\hline $\begin{array}{l}\text { A organização possui } \\
\text { sistemas de Tecnologia da } \\
\text { Informação em rede para a } \\
\text { coleta e distribuição dos } \\
\text { indicadores de desempenho } \\
\text { que permitem aos usuários } \\
\text { verem os dados necessários } \\
\text { em tempo hábil para a } \\
\text { tomada de decisão. }\end{array}$ & 2,50 & 1,00 & 1,75 & 3,50 & 3,00 & 3,25 & 5,00 & 1,50 & 3,25 \\
\hline Nível de Maturidade & 2,50 & 2,64 & 2,57 & 3,00 & 4,07 & 3,54 & 4,64 & 2,36 & 3,50 \\
\hline
\end{tabular}

No Quadro 25, são apresentadas as principais dificuldades apontadas pelos respondentes na dimensão Mensuração de Desempenho.

Quadro 25 - Principais dificuldades na dimensão Mensuração de Desempenho

\begin{tabular}{|c|c|c|l|}
\hline Organização & Área & Respondente & \multicolumn{2}{|c|}{ Descrição } \\
\hline O1 & E & R1 & $\begin{array}{l}\text { Embora haja tecnologia suficiente para mensurar o } \\
\text { desempenho, a cultura organizacional ainda não } \\
\text { absorveu a importância de fazê-lo. }\end{array}$ \\
\hline O1 & E & R2 & $\begin{array}{l}\text { Os indicadores não representam a organização como um } \\
\text { todo e não abrangem todas as dimensões. O indicador de } \\
\text { satisfação do usuário é fraco em abrangência uma vez } \\
\text { que captura apenas uma pequena parcela de usuários. }\end{array}$ \\
\hline
\end{tabular}


Quadro 25 - Principais dificuldades na dimensão Mensuração de Desempenho (continuação) \begin{tabular}{ll|ll} 
Organização Área & Respondente Descrição
\end{tabular}

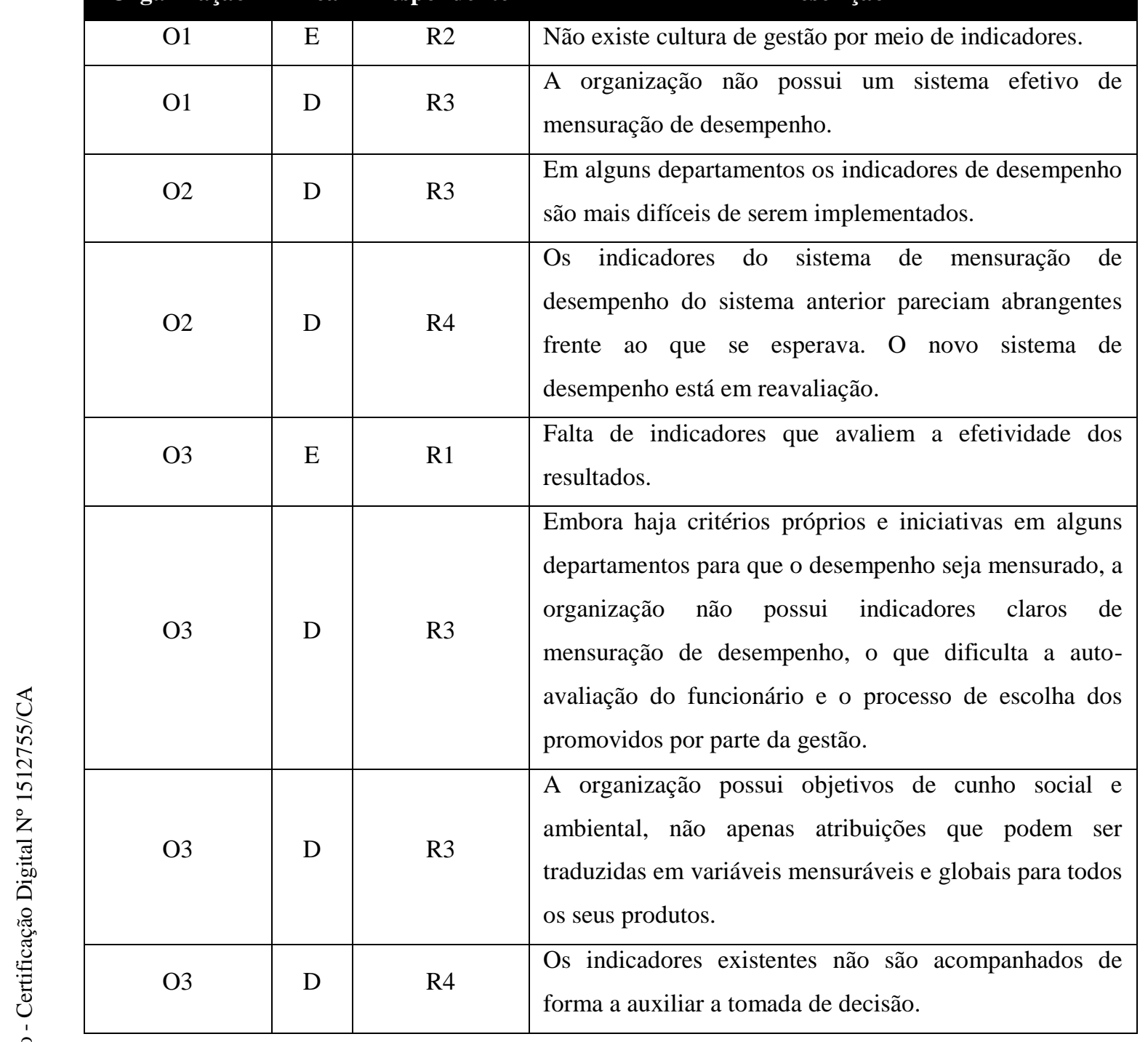

Com base na análise feita do Quadro 25, é possível observar três semelhanças entre as principais dificuldades encontradas:

1. Falta de um sistema de indicadores que esteja em conformidade com as boas práticas (cinco citações). Esses colaboradores indicaram problemas com algumas características dos indicadores existentes nas instituições como abrangência, clareza, efetividade e representatividade.

2. Falta de uma cultura organizacional que valorize a gestão pro meio de indicadores (duas citações).

3. Dificuldade de implementar indicadores pela complexidade do departamento ou do assunto a ser mensurado (duas citações). 
No Quadro 26, são apresentadas as soluções de melhorias apontadas pelos respondentes na dimensão Mensuração de Desempenho.

Quadro 26 - Soluções de melhorias na dimensão Mensuração de Desempenho

\begin{tabular}{|c|c|c|c|}
\hline Organização & Área & Respondente & Descrição \\
\hline $\mathrm{O} 1$ & E & R1 & $\begin{array}{l}\text { Contratação de analistas e constituição de equipes } \\
\text { exclusivas para monitoramento dos indicadores gerenciais. }\end{array}$ \\
\hline $\mathrm{O} 1$ & E & R1 & $\begin{array}{l}\text { Capacitação dos servidores responsáveis pelo registro de } \\
\text { informações no sistema de monitoramento. }\end{array}$ \\
\hline $\mathrm{O} 1$ & E & R1 & $\begin{array}{l}\text { Realização de seminários de sensibilização sobre a } \\
\text { importância da mensuração de desempenho. }\end{array}$ \\
\hline $\mathrm{O} 1$ & E & R2 & $\begin{array}{l}\text { Rever, e se necessário redefinir, os indicadores de } \\
\text { desempenho que existem atualmente na organização. }\end{array}$ \\
\hline $\mathrm{O} 1$ & E & R2 & $\begin{array}{l}\text { Redefinir a avaliação de desempenho para um modelo } \\
\text { voltado para indicadores de desempenho. }\end{array}$ \\
\hline $\mathrm{O} 1$ & D & R3 & $\begin{array}{l}\text { Criação de um grupo de trabalho para desenvolver e } \\
\text { implementar um sistema efetivo de indicadores de } \\
\text { desempenho. }\end{array}$ \\
\hline $\mathrm{O} 2$ & E & R2 & $\begin{array}{l}\text { Implantação de uma sistemática de avaliação de } \\
\text { desempenho do planejamento estratégico totalmente } \\
\text { patrocinada pela alta direção. Com cobranças e } \\
\text { monitoramento constante no âmbito da execução e } \\
\text { resultados alcançados. }\end{array}$ \\
\hline $\mathrm{O} 2$ & E & R3 & $\begin{array}{l}\text { É necessário não somente medir o desempenho, como } \\
\text { recompensá-lo, sem subjetividade. }\end{array}$ \\
\hline $\mathrm{O} 3$ & E & R1 & $\begin{array}{l}\text { Aprimorar as práticas de monitoramento e avaliação no } \\
\text { âmbito da efetividade dos resultados. }\end{array}$ \\
\hline $\mathrm{O} 3$ & D & R3 & $\begin{array}{l}\text { Desenvolvimento de um sistema de indicadores } \\
\text { balanceados para toda a organização. }\end{array}$ \\
\hline $\mathrm{O} 3$ & D & R3 & $\begin{array}{l}\text { Mesmo considerando as particularidades de cada produto, } \\
\text { é importante que haja um empenho maior por parte da } \\
\text { organização em comunicar o resultado das decisões } \\
\text { gerenciais de modo a aumentar a eficiência e o dinamismo. }\end{array}$ \\
\hline $\mathrm{O} 3$ & D & R4 & $\begin{array}{l}\text { Estruturação de um sistema de indicadores que seja } \\
\text { iniciado a partir de uma estratégia clara e desdobre-se até o } \\
\text { nível individual. Tais indicadores deveriam ser } \\
\text { monitorados com mais frequência pelos líderes dos } \\
\text { diferentes níveis (gerente, chefe, superintendente e } \\
\text { diretor), com vistas à auxiliar a tomada de decisão. }\end{array}$ \\
\hline
\end{tabular}


A partir da análise do Quadro 26, é possível observar duas semelhanças entre as soluções de melhorias apontadas pelos respondentes:

1. Redefinição e implementação de indicadores de desempenho em conformidade com as boas práticas (seis citações, sendo pelo menos uma por organização).

2. Criação de grupos especializados com a função de desenvolver e monitorar os indicadores de desempenho organizacionais (duas citações).

\subsection{6.}

\section{Gerenciamento de Desempenho}

Com base no $S M M M^{\mathrm{TM}}$ e na análise da Tabela 6 , observa-se que as três organizações classificam-se como estruturadas e pró-ativas (com pontuação entre 2,5 e 3,49), conforme pode ser observado no Quadro 15. Esse nível de maturidade é

o terceiro em uma escala de um a cinco, representando que as organizações possuem nível mediano de desenvolvimento na dimensão Gerenciamento de Desempenho.

Tabela 6 - Respostas dos questionários na dimensão Gerenciamento de Desempenho

\begin{tabular}{|c|c|c|c|c|c|c|c|c|c|}
\hline & O1E & O1D & $\mathrm{O} 1 \mathrm{G}$ & $\mathrm{O} 2 \mathrm{E}$ & $\mathrm{O} 2 \mathrm{D}$ & $\mathrm{O} 2 \mathrm{G}$ & O3E & O3D & $\mathrm{O} 3 \mathrm{G}$ \\
\hline $\begin{array}{l}\text { A organização é reconhecida } \\
\text { como um sistema dinâmico. }\end{array}$ & 3,50 & 3,50 & 3,50 & 3,50 & 3,00 & 3,25 & 2,00 & 3,00 & 2,50 \\
\hline $\begin{array}{l}\text { A organização utiliza ciclos } \\
\text { de feedbacks para que os } \\
\text { gerentes possam ter ciência } \\
\text { dos resultados das suas } \\
\text { decisões. }\end{array}$ & 2,00 & 3,50 & 2,75 & 3,00 & 4,50 & 3,75 & 4,00 & 3,00 & 3,50 \\
\hline $\begin{array}{l}\text { Os gestores são capazes de } \\
\text { fazer mudanças com base } \\
\text { em relatórios apresentados } \\
\text { em tempo hábil. }\end{array}$ & 2,00 & 2,50 & 2,25 & 3,50 & 2,50 & 3,00 & 3,50 & 3,50 & 3,50 \\
\hline $\begin{array}{l}\text { Os indicadores } \\
\text { desempenho de } \\
\text { estão disponíveis para } \\
\text { avaliar a estratégia. }\end{array}$ & 4,00 & 2,50 & 3,25 & 2,50 & 2,00 & 2,25 & 5,00 & 2,00 & 3,50 \\
\hline $\begin{array}{l}\text { Os líderes colocam a } \\
\text { organização em um ciclo de } \\
\text { aprendizagem. }\end{array}$ & 3,00 & 2,00 & 2,50 & 3,50 & 1,50 & 2,50 & 4,00 & 3,00 & 3,50 \\
\hline $\begin{array}{l}\text { A organização está } \\
\text { aprendendo o que funciona } \\
\text { para satisfazer o consumidor } \\
\text { e melhorar a organização. }\end{array}$ & 4,00 & 2,00 & 3,00 & 4,00 & 3,50 & 3,75 & 3,50 & 4,00 & 3,75 \\
\hline Nível de Maturidade & 3,08 & 2,67 & 2,88 & 3,33 & 2,83 & 3,08 & 3,67 & 3,08 & 3,38 \\
\hline
\end{tabular}


No Quadro 27, são apresentadas as principais dificuldades apontadas pelos respondentes na dimensão Gerenciamento de Desempenho.

Quadro 27 - Principais dificuldades na dimensão Gerenciamento de Desempenho

\begin{tabular}{|c|c|c|c|}
\hline Organização & Área & Respondente & Descrição \\
\hline O1 & $\mathrm{E}$ & $\mathrm{R} 1$ & $\begin{array}{l}\text { Não há definição de indicadores simples e de fácil } \\
\text { interpretação. }\end{array}$ \\
\hline O1 & $\mathrm{E}$ & $\mathrm{R} 1$ & $\begin{array}{l}\text { As bases de dados encontram-se, muitas vezes, } \\
\text { inconsistentes. }\end{array}$ \\
\hline O1 & $\mathrm{E}$ & $\mathrm{R} 1$ & $\begin{array}{l}\text { A incorporação de mais essa atividade, como atividade } \\
\text { rotineira, esbarra na cultura organizacional que não tem } \\
\text { por hábito refletir sobre desempenho. }\end{array}$ \\
\hline O1 & $\mathrm{E}$ & $\mathrm{R} 2$ & $\begin{array}{l}\text { Ausência de indicadores que demonstrem o desempenho } \\
\text { da instituição. }\end{array}$ \\
\hline O1 & $\mathrm{E}$ & R2 & $\begin{array}{l}\text { Falta de comprometimento da alta direção com a } \\
\text { avaliação de desempenho da instituição. }\end{array}$ \\
\hline O1 & $\mathrm{D}$ & R3 & Os processos e procedimentos são lentos. \\
\hline O1 & $\mathrm{D}$ & R3 & $\begin{array}{l}\text { Falta de mecanismos de recompensa e punição para o } \\
\text { cumprimento de prazos. }\end{array}$ \\
\hline O1 & $\mathrm{D}$ & R4 & $\begin{array}{l}\text { Os feedbacks não chegam ou não chegam em tempo hábil } \\
\text { para a efetiva tomada de decisão. }\end{array}$ \\
\hline $\mathrm{O} 2$ & $\mathrm{E}$ & R1 & $\begin{array}{l}\text { A organização tem dificuldade de lidar com medição de } \\
\text { seu desempenho por meio de indicadores. }\end{array}$ \\
\hline $\mathrm{O} 2$ & $\mathrm{E}$ & $\mathrm{R} 2$ & $\begin{array}{l}\text { A organização sabe identificar o que funciona para } \\
\text { cumprir suas funções e alcançar seus objetivos, muito } \\
\text { mais pelo conhecimento e experiência de seus lideres e } \\
\text { servidores do que pelo auxílio de uma sistemática que } \\
\text { leve primordialmente os resultados apresentados por } \\
\text { indicadores de desempenho. }\end{array}$ \\
\hline $\mathrm{O} 2$ & $\mathrm{D}$ & R3 & $\begin{array}{l}\text { Como há uma hierarquização forte, há sempre receio de } \\
\text { dar um feedback negativo a um superior. }\end{array}$ \\
\hline $\mathrm{O} 2$ & $\mathrm{D}$ & $\mathrm{R} 4$ & $\begin{array}{l}\text { O gerenciamento de desempenho foi descontinuado } \\
\text { recentemente para reavaliação, visto que dava margem a } \\
\text { distorções profundas. A autoavaliação era vista como o } \\
\text { principal problema, já que existia a possibilidade de um } \\
\text { servidor poder atribuir-se notas máximas, levando } \\
\text { vantagem sobre outro servidor que registrava as } \\
\text { informações que julgava corretas. }\end{array}$ \\
\hline $\mathrm{O} 3$ & $\mathrm{E}$ & $\mathrm{R} 1$ & $\begin{array}{l}\text { Indisponibilidade de informações comparativas } \\
\text { (benchmarks). }\end{array}$ \\
\hline
\end{tabular}


A partir da análise do Quadro 27, é possível observar duas semelhanças entre as principais dificuldades encontradas:

1. Inexistência total ou parcial de indicadores de desempenho em conformidade com as boas práticas (quatro citações). Tal dificuldade já foi relatada na dimensão anterior, porém como o gerenciamento do desempenho da organização tem como base a dimensão Mensuração de Desempenho - uma vez que sem a mensuração da informação sobre desempenho, não há o que gerenciar - essa dificuldade foi reiterada pelos respondentes.

2. Problemas no que diz respeito ao feedback (duas citações). Esses respondentes indicaram coisas distintas sobre esse tema, tendo o primeiro indicado a inexistência ou lentidão na chegada do feedback para a tomada de decisão, e o segundo relatado o receio, por parte dos funcionários, em dar feedbacks negativos a um superior.

No Quadro 28, são apresentadas as soluções de melhorias apontadas pelos respondentes na dimensão Gerenciamento de Desempenho.

Quadro 28 - Soluções de melhorias na dimensão Gerenciamento de Desempenho

\begin{tabular}{|c|c|c|c|}
\hline Organização & Área & Respondente & Descrição \\
\hline O1 & $\mathrm{E}$ & $\mathrm{R} 1$ & $\begin{array}{l}\text { Definição de um pequeno número de indicadores que } \\
\text { abranja toda a instituição. }\end{array}$ \\
\hline O1 & $\mathrm{E}$ & $\mathrm{R} 1$ & $\begin{array}{l}\text { Realização de seminários de sensibilização sobre a } \\
\text { importância do gerenciamento de desempenho. }\end{array}$ \\
\hline O1 & $\mathrm{E}$ & $\mathrm{R} 1$ & $\begin{array}{l}\text { Capacitação das equipes de monitores de desempenho } \\
\text { acerca do tema e da ferramenta a ser utilizada. }\end{array}$ \\
\hline $\mathrm{O} 1$ & $\mathrm{E}$ & $\mathrm{R} 1$ & Produção e disseminação ampla de relatórios analíticos. \\
\hline $\mathrm{O} 1$ & $\mathrm{E}$ & $\mathrm{R} 2$ & $\begin{array}{l}\text { Rever, e se necessário redefinir, os indicadores de } \\
\text { desempenho que existem atualmente na organização. }\end{array}$ \\
\hline $\mathrm{O} 1$ & $\mathrm{E}$ & $\mathrm{R} 2$ & $\begin{array}{l}\text { Elaboração de relatórios gerenciais para análise do } \\
\text { desempenho. }\end{array}$ \\
\hline $\mathrm{O} 1$ & $\mathrm{D}$ & R3 & $\begin{array}{l}\text { Capacitação dos gestores acerca do gerenciamento de } \\
\text { desempenho. }\end{array}$ \\
\hline $\mathrm{O} 1$ & $\mathrm{D}$ & $\mathrm{R} 3$ & $\begin{array}{l}\text { Incentivo á mudança cultural que desenvolva na } \\
\text { organização a cultura do gerenciamento de desempenho } \\
\text { como prática de gestão. }\end{array}$ \\
\hline
\end{tabular}


Quadro 28 - Soluções de melhorias na dimensão Gerenciamento de Desempenho (continuação) \begin{tabular}{ll|ll} 
Organização Área & Respondente Descrição
\end{tabular}

\begin{tabular}{|c|l|l|l|}
\hline O1 & D & R4 & $\begin{array}{l}\text { Os resultados devem ser reportados de forma mais } \\
\text { dinâmica e menos compulsória. }\end{array}$ \\
\hline O2 & E & R1 & $\begin{array}{l}\text { Aumentar a maturidade de forma gradativa, através de } \\
\text { ações de capacitação, comunicação, etc, no âmbito do } \\
\text { gerenciamento de desempenho na organização. }\end{array}$ \\
\hline O2 & E & R1 & $\begin{array}{l}\text { Realização de trabalhos pilotos para a implementação do } \\
\text { gerenciamento de desempenho. }\end{array}$ \\
\hline O2 & E & R2 & $\begin{array}{l}\text { Implantação de uma sistemática de avaliação de } \\
\text { desempenho do planejamento estratégico totalmente } \\
\text { patrocinada pela alta direção, sem perder a habilidade já } \\
\text { conquistada em promover melhorias e inovação pela } \\
\text { experiência e conhecimento. }\end{array}$ \\
\hline O3 & E & R1 & $\begin{array}{l}\text { As práticas de benchmarking devem ser difundidas } \\
\text { dentro da organização. }\end{array}$ \\
\hline
\end{tabular}

A partir da análise do Quadro 28, é possível observar três semelhanças entre as soluções de melhorias apontadas pelos respondentes:

1. Investimento em capacitação para gestores e funcionários da organização (três citações). Sobre esse fato, os colaboradores identificam que gestores e funcionários devem ser melhor preparados, por meio de capacitações, para entender melhor sobre o gerenciamento de desempenho.

2. Redefinição e implementação de indicadores de desempenho em conformidade com as boas práticas (três citações). Tal solução de melhoria, assim como nas principais dificuldades encontradas em relação a essa temática, já foi exposta na dimensão Mensuração de Desempenho, porém é considerada relevante também no âmbito da dimensão Gerenciamento de Desempenho, conforme explicitado na análise do Quadro 27.

3. Maior produção e disseminação de relatórios gerenciais para a análise de desempenho (duas citações). 


\subsection{7.}

\section{Melhoria de Processos}

Com base no $S M M M^{\mathrm{TM}}$ e na análise da Tabela 7 , observa-se que uma organização $(\mathrm{O} 3)$ classifica-se como estruturada e pró-ativa (com pontuação entre 2,5 e 3,49), enquanto duas organizações (O1 e O2) classificam-se como gerenciadas e focadas (com pontuação entre 3,5 e 4,49), conforme pode ser observado no Quadro 15. Os níveis de maturidade supracitados representam o terceiro e quatro estágio de maturidade, respectivamente. O nível três representa que a organização possui desempenho mediano na dimensão Melhoria de Processos, enquanto o nível quatro demonstra que as instituições possuem bom desempenho no âmbito dessa dimensão. Sobre a Tabela 7 , é importante ressaltar, ainda, que ambos os respondentes das demais áreas da organização 1 não souberam informar se os processos estrategicamente importantes dessa organização são eficientes quando comparados com organizações similares, nem se a organização possui planos de contingência para riscos futuros.

Tabela 7 - Respostas dos questionários na dimensão Melhoria de Processos

\begin{tabular}{|c|c|c|c|c|c|c|c|c|c|}
\hline & O1E & O1D & $\mathrm{O} 1 \mathrm{C}$ & $\mathrm{O} 2 \mathrm{E}$ & $\mathrm{O} 2 \mathrm{D}$ & $\mathrm{O} 2 \mathrm{G}$ & O3E & $\mathrm{O} 3 \mathrm{D}$ & $\mathrm{O} 3 \mathrm{G}$ \\
\hline $\begin{array}{lr}\text { A organização } & \text { possui } \\
\text { conhecimento de } & \text { seus } \\
\text { processos de } & \text { trabalho } \\
\text { estrategicamente } & \\
\text { importantes. } & \\
\end{array}$ & 4,00 & 3,50 & 3,75 & 4,00 & 5,00 & 4,50 & 4,00 & 4,50 & 4,25 \\
\hline $\begin{array}{lr}\text { Os } & \text { processos } \\
\text { estrategicamente } & \\
\text { importantes } & \text { são } \\
\text { continuamente atualizados e } \\
\text { documentados. }\end{array}$ & 3,50 & 3,50 & 3,50 & 2,00 & 3,50 & 2,75 & 5,00 & 3,00 & 4,00 \\
\hline $\begin{array}{l}\text { Os } \\
\text { estrategicamente } \\
\text { importantes são eficientes } \\
\text { quando comparados com } \\
\text { organizações similares. }\end{array}$ & 5,00 & - & 5,00 & 3,00 & 5,00 & 4,00 & 4,50 & 3,00 & 3,75 \\
\hline $\begin{array}{l}\text { As habilidades, práticas e } \\
\text { tecnologias são usadas para } \\
\text { melhorar a qualidade e } \\
\text { eficiência dos processos. }\end{array}$ & 4,50 & 3,50 & 4,00 & 4,00 & 4,00 & 4,00 & 3,00 & 2,00 & 2,50 \\
\hline $\begin{array}{l}\text { A organização possui } \\
\text { conhecimento de suas } \\
\text { competências centrais e } \\
\text { capacidades, e de como elas } \\
\text { são empregadas na execução } \\
\text { dos processos. }\end{array}$ & 4,00 & 4,00 & 4,00 & 3,50 & 4,50 & 4,00 & 3,00 & 2,50 & 2,75 \\
\hline
\end{tabular}


Tabela 7 - Respostas dos questionários na dimensão Melhoria de Processos (continuação)

\begin{tabular}{|c|c|c|c|c|c|c|c|c|c|}
\hline & O1E & O1D & $\mathrm{O} 1 \mathrm{G}$ & $\mathrm{O} 2 \mathrm{E}$ & O2D & $\mathrm{O} 2 \mathrm{G}$ & O3E & O3D & $\mathrm{O} 3 \mathrm{G}$ \\
\hline $\begin{array}{l}\text { Os funcionários conhecem } \\
\text { os clientes da organização e } \\
\text { suas expectativas. }\end{array}$ & 4,00 & 4,50 & 4,25 & 4,00 & 4,00 & 4,00 & 3,00 & 4,00 & 3,50 \\
\hline $\begin{array}{l}\text { A organização possui planos } \\
\text { de contingência para riscos } \\
\text { futuros, como desastres, } \\
\text { escassez de financiamento e } \\
\text { sucessão de liderança. }\end{array}$ & 2,00 & - & 2,00 & 4,00 & 5,00 & 4,50 & 2,00 & 2,00 & 2,00 \\
\hline Nível de Maturidade & 3,86 & 3,80 & 3,79 & 3,50 & 4,43 & 3,96 & 3,50 & 3,00 & 3,25 \\
\hline
\end{tabular}

No Quadro 29, são apresentadas as principais dificuldades apontadas pelos respondentes na dimensão Melhoria de Processos.

Quadro 29 - Principais dificuldades na dimensão Melhoria de Processos

\begin{tabular}{|c|c|c|c|}
\hline Organização & Área & Respondente & Descrição \\
\hline O1 & $\mathrm{E}$ & $\mathrm{R} 1$ & $\begin{array}{l}\text { A gestão por processo já está disseminada } \\
\text { parcialmente na instituição. A dificuldade atual é } \\
\text { garantir equipe de trabalho em número suficiente para } \\
\text { dinamizar o projeto. }\end{array}$ \\
\hline O1 & $\mathrm{E}$ & $\mathrm{R} 2$ & $\begin{array}{l}\text { A gestão por processo vem sendo explorada pela } \\
\text { instituição. A dificuldade maior é mudar a visão } \\
\text { departamental funcional para a visão por processo. }\end{array}$ \\
\hline O1 & $\mathrm{E}$ & $\mathrm{R} 2$ & $\begin{array}{l}\text { A comparabilidade dos processos é difícil, uma vez } \\
\text { não há instituições com as mesmas características no } \\
\text { país. Recentemente, a organização percebeu a } \\
\text { possibilidade de comparar suas práticas com as boas } \\
\text { práticas internacionais e está realizando tal atividade. }\end{array}$ \\
\hline $\mathrm{O} 2$ & $\mathrm{E}$ & $\mathrm{R} 1$ & $\begin{array}{l}\text { O tema gestão de processo ainda não está plenamente } \\
\text { consolidado na organização. }\end{array}$ \\
\hline $\mathrm{O} 2$ & $\mathrm{E}$ & $\mathrm{R} 1$ & $\begin{array}{l}\text { A organização não possui como cultura a atualização e } \\
\text { documentação, de forma contínua, dos processo } \\
\text { estratégicos. }\end{array}$ \\
\hline $\mathrm{O} 2$ & $\mathrm{D}$ & $\mathrm{R} 3$ & Os processos não são continuamente atualizados. \\
\hline $\mathrm{O} 2$ & $\mathrm{D}$ & R3 & $\begin{array}{l}\text { Há determinados processos de trabalho que são } \\
\text { realizados de uma maneira, porém as pessoas não } \\
\text { sabem porque trabalham dessa forma. }\end{array}$ \\
\hline
\end{tabular}


Quadro 29 - Principais dificuldades na dimensão Melhoria de Processos (continuação)

\begin{tabular}{|c|c|c|c|}
\hline Organização & Área & Respondente & Descrição \\
\hline $\mathrm{O} 2$ & $\mathrm{D}$ & $\mathrm{R} 4$ & $\begin{array}{l}\text { Os macroprocessos foram mapeados há alguns anos e } \\
\text { os processos constituintes estão ainda em fase de } \\
\text { definição. A principal dificuldade é a falta de } \\
\text { divulgação da metodologia e ferramentas para } \\
\text { mapeamento dos processos, de forma a obter a } \\
\text { interação de todos os componentes interessados. }\end{array}$ \\
\hline $\mathrm{O} 3$ & $\mathrm{E}$ & R1 & $\begin{array}{l}\text { A dificuldade nessa dimensão é conciliar a visão } \\
\text { departamental funcional com a visão por processo. }\end{array}$ \\
\hline $\mathrm{O} 3$ & $\mathrm{E}$ & $\mathrm{R} 2$ & $\begin{array}{l}\text { A organização possui conhecimento parcial de suas } \\
\text { competências centrais e capacidades e de como elas } \\
\text { são empregadas na execução dos processos. }\end{array}$ \\
\hline $\mathrm{O} 3$ & $\mathrm{D}$ & $\mathrm{R} 3$ & $\begin{array}{l}\text { A organização possui dificuldade para registrar os } \\
\text { processos empregados na execução das atividades, o } \\
\text { que dificulta a transmissão do conhecimento e a } \\
\text { identificação de melhorias dos processos. }\end{array}$ \\
\hline $\mathrm{O} 3$ & $\mathrm{D}$ & $\mathrm{R} 4$ & $\begin{array}{l}\text { A organização é preocupada em estabelecer normas } \\
\text { que disciplinem a execução de atividades relevantes. } \\
\text { No entanto, não há, de maneira geral, uma avaliação da } \\
\text { eficiência dos processos em si para execução das } \\
\text { atividades. }\end{array}$ \\
\hline
\end{tabular}

Com base na análise feita do Quadro 29, é possível observar duas semelhanças entre as principais dificuldades encontradas:

1. Falta de atualização constante dos processos de trabalho (duas citações).

2. Dificuldade de conciliação entre a visão departamental funcional e a visão por processo (duas citações).

No Quadro 30, são apresentadas as soluções de melhorias apontadas pelos respondentes na dimensão Melhoria de Processos. 
Quadro 30 - Soluções de melhorias na dimensão Melhoria de Processos

\begin{tabular}{|c|c|c|c|}
\hline Organização & Área & Respondente & Descrição \\
\hline O1 & $\mathrm{E}$ & $\mathrm{R} 1$ & $\begin{array}{l}\text { Capacitação de funcionários que atuam como } \\
\text { mapeadores de processos, assim como de analistas de } \\
\text { processos para condução das reuniões de validação. }\end{array}$ \\
\hline $\mathrm{O} 1$ & $\mathrm{E}$ & $\mathrm{R} 2$ & $\begin{array}{l}\text { Capacitação dos funcionários no âmbito da gestão por } \\
\text { processos objetivando a mudança da visão } \\
\text { departamental para a visão por processo. }\end{array}$ \\
\hline O1 & $\mathrm{E}$ & $\mathrm{R} 2$ & $\begin{array}{l}\text { Maior ênfase na comparabilidade dos processos de } \\
\text { trabalho com organizações internacionais de forma a } \\
\text { auxiliar a instituição na melhora de seus processos de } \\
\text { trabalho, assim como na implementação de uma } \\
\text { mudança efetiva. }\end{array}$ \\
\hline $\mathrm{O} 2$ & $\mathrm{E}$ & $\mathrm{R} 1$ & $\begin{array}{l}\text { Utilizar projetos pilotos como forma de internalizar a } \\
\text { gestão por processos na organização. }\end{array}$ \\
\hline $\mathrm{O} 2$ & $\mathrm{E}$ & $\mathrm{R} 2$ & $\begin{array}{l}\text { Implantar um gerenciamento sistemático dos processos } \\
\text { estrategicamente importantes. }\end{array}$ \\
\hline $\mathrm{O} 2$ & $\mathrm{D}$ & $\mathrm{R} 3$ & $\begin{array}{l}\text { A maior alternância na direção e também em níveis } \\
\text { gerenciais mais baixos faria como que os processos de } \\
\text { trabalho fossem revisados e alterados, se necessário, } \\
\text { mais rapidamente. }\end{array}$ \\
\hline $\mathrm{O} 3$ & $\mathrm{E}$ & $\mathrm{R} 1$ & $\begin{array}{l}\text { Demonstrar a importância, através da capacitação, da } \\
\text { visão por processo e criar incentivos para que essa } \\
\text { visão seja valorizada. }\end{array}$ \\
\hline $\mathrm{O} 3$ & $\mathrm{E}$ & $\mathrm{R} 2$ & $\begin{array}{l}\text { Implementação de um programa de capacitação, no } \\
\text { âmbito do mapeamento ou desenvolvimento de } \\
\text { competências. }\end{array}$ \\
\hline $\mathrm{O} 3$ & $\mathrm{D}$ & $\mathrm{R} 3$ & $\begin{array}{l}\text { Documentação de processos relevantes para a } \\
\text { organização e maior emprego das tecnologias } \\
\text { disponíveis. }\end{array}$ \\
\hline $\mathrm{O} 3$ & $\mathrm{D}$ & R4 & Avaliação dos processos com base na eficiência. \\
\hline
\end{tabular}

A partir da análise do Quadro 30, é possível observar somente uma semelhança entre as soluções de melhorias apontadas pelos respondentes:

1. Realização de capacitações no âmbito da gestão por processo (quatro citações). 


\subsection{8.}

\section{Sustentabilidade do Gerenciamento Estratégico}

Com base no $S M M M^{\mathrm{TM}}$ e na análise da Tabela 8 , observa-se que as três organizações classificam-se como estruturadas e pró-ativas (com pontuação entre 2,5 e 3,49), conforme pode ser observado no Quadro 15. Esse nível de maturidade é o terceiro em uma escala de um a cinco, representando que as organizações possuem nível mediano de desenvolvimento na dimensão Sustentabilidade do Gerenciamento Estratégico.

Tabela 8 - Respostas dos questionários na dimensão Sustentabilidade do Gerenciamento Estratégico

\begin{tabular}{|c|c|c|c|c|c|c|c|c|c|}
\hline & O1E & O1D & $\mathrm{O} 1 \mathrm{G}$ & $\mathrm{O} 2 \mathrm{E}$ & $\mathrm{O} 2 \mathrm{D}$ & $\mathrm{O} 2 \mathrm{G}$ & $\mathrm{O} 3 \mathrm{E}$ & O3D & $\mathrm{O} 3 \mathrm{G}$ \\
\hline \begin{tabular}{llrr} 
A organização & \multicolumn{2}{c}{ mantém o } \\
foco na & sua varão & visã \\
estratégica, & planos & e \\
iniciativas. & & &
\end{tabular} & 3,50 & 4,00 & 3,75 & 3,00 & 3,50 & 3,25 & 4,00 & 4,00 & 4,00 \\
\hline $\begin{array}{l}\text { Funcionários, sistemas e } \\
\text { atividades de comunicação } \\
\text { estão disponíveis para } \\
\text { manter o momentum de } \\
\text { mudança desejada. }\end{array}$ & 3,00 & 4,00 & 3,50 & 3,00 & 3,00 & 3,00 & 4,00 & 3,00 & 3,50 \\
\hline $\begin{array}{l}\text { Os funcionários possuem } \\
\text { senso de urgência. }\end{array}$ & 3,50 & 2,50 & 3,00 & 4,50 & 3,00 & 3,75 & 2,50 & 4,00 & 3,25 \\
\hline $\begin{array}{l}\text { A organização possui } \\
\text { sistemas de recompensa e } \\
\text { reconhecimento para } \\
\text { estimular esforços visando } \\
\text { motivar os funcionários a } \\
\text { realizar as atividades } \\
\text { corretas. }\end{array}$ & 1,50 & 1,00 & 1,25 & 2,00 & 1,50 & 1,75 & 2,50 & 2,00 & 2,25 \\
\hline $\begin{array}{l}\text { A organização possui líderes } \\
\text { mobilizadores que mantêm } \\
\text { os funcionários informados } \\
\text { sobre as prioridades } \\
\text { estratégicas e os níveis de } \\
\text { desempenho desejados. }\end{array}$ & 3,00 & 3,00 & 3,00 & 2,50 & 2,00 & 2,25 & 3,00 & 3,00 & 3,00 \\
\hline $\begin{array}{l}\text { A organização possui uma } \\
\text { unidade de gestão } \\
\text { estratégica para implantar a } \\
\text { estratégia e monitorar o } \\
\text { desempenho. }\end{array}$ & 4,00 & 3,00 & 3,50 & 3,50 & 5,00 & 4,25 & 5,00 & 2,50 & 3,75 \\
\hline 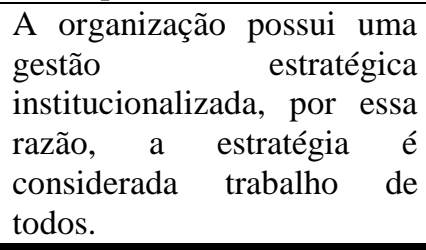 & 4,00 & 3,00 & 3,50 & 3,50 & 2,00 & 2,75 & 4,50 & 2,00 & 3,25 \\
\hline Nível de Maturidade & 3,21 & 2,93 & 3,07 & 3,14 & 2,86 & 3,00 & 3,64 & 2,93 & 3,29 \\
\hline
\end{tabular}


No Quadro 31, são apresentadas as principais dificuldades apontadas pelos respondentes na dimensão Sustentabilidade do Gerenciamento Estratégico.

Quadro 31 - Principais dificuldades na dimensão Sustentabilidade do Gerenciamento Estratégico

\begin{tabular}{|c|c|c|c|}
\hline Organização & Área & Respondente & Descrição \\
\hline $\mathrm{O} 1$ & $\mathrm{E}$ & $\mathrm{R} 2$ & $\begin{array}{l}\text { A estratégia compete com as atividades de rotina e } \\
\text { demais processos de trabalho, o que dificulta a } \\
\text { compreensão de que a estratégia é trabalho de todos. }\end{array}$ \\
\hline $\mathrm{O} 1$ & $\mathrm{E}$ & R2 & $\begin{array}{l}\text { Não há um sistema de recompensas pelo alcance de } \\
\text { resultados. }\end{array}$ \\
\hline $\mathrm{O} 1$ & $\mathrm{D}$ & $\mathrm{R} 3$ & Falta de incentivos para o desenvolvimento na carreira. \\
\hline $\mathrm{O} 1$ & $\mathrm{D}$ & R4 & $\begin{array}{l}\text { Existe pouca influência do planejamento estratégico nas } \\
\text { rotinas de trabalho da instituição. }\end{array}$ \\
\hline $\mathrm{O} 2$ & $\mathrm{E}$ & R1 & $\begin{array}{l}\text { A visão estratégica é muito dinâmica e o processo de } \\
\text { mudança ocorre de forma lenta pelo tamanho da } \\
\text { organização e especificidades das áreas. }\end{array}$ \\
\hline $\mathrm{O} 2$ & $\mathrm{E}$ & R1 & $\begin{array}{l}\text { Os líderes tendem a demorar a fazer o alinhamento da } \\
\text { estratégia com as demais atividades da unidade pela } \\
\text { complexidade de suas agendas. }\end{array}$ \\
\hline $\mathrm{O} 2$ & $\mathrm{D}$ & R3 & $\begin{array}{l}\text { A principal dificuldade está na meritocracia. Não existem } \\
\text { incentivos adequados para que o funcionário busque seu } \\
\text { melhor desempenho. Tal fato se dá por dois motivos, o } \\
\text { valor não atrativo das comissões e a falta da meritocracia } \\
\text { para escolha dos ocupantes em cargos de comissão. }\end{array}$ \\
\hline $\mathrm{O} 2$ & $\mathrm{D}$ & R3 & $\begin{array}{l}\text { Embora a organização se identifique como parte de um } \\
\text { sistema dinâmico, o processo de mudança é lento. }\end{array}$ \\
\hline $\mathrm{O} 2$ & $\mathrm{D}$ & R4 & $\begin{array}{l}\text { Existe uma unidade de gestão estratégica, mas seus } \\
\text { trabalhos e resultados não envolvem toda a organização. } \\
\text { Além disso, o seu funcionamento é pouco conhecido. }\end{array}$ \\
\hline $\mathrm{O} 3$ & $\mathrm{E}$ & R1 & Os sistemas de incentivos são limitados. \\
\hline $\mathrm{O} 3$ & $\mathrm{E}$ & R2 & $\begin{array}{l}\text { A organização possui somente alguns líderes } \\
\text { mobilizadores que mantêm os funcionários informados } \\
\text { sobre as prioridades estratégicas e os níveis de } \\
\text { desempenho desejados. }\end{array}$ \\
\hline $\mathrm{O} 3$ & D & R3 & $\begin{array}{l}\text { A organização não monitora continuamente o } \\
\text { desempenho da estratégia. }\end{array}$ \\
\hline $\mathrm{O} 3$ & D & R3 & $\begin{array}{l}\text { Não há um sistema de reconhecimento para estimular os } \\
\text { funcionários a realizarem as atividades corretas. }\end{array}$ \\
\hline $\mathrm{O} 3$ & D & R4 & $\begin{array}{l}\text { Os sistemas de recompensa e reconhecimento não } \\
\text { apresentam critérios claros e são pouco flexíveis. }\end{array}$ \\
\hline
\end{tabular}


Com base na análise feita do Quadro 31, é possível observar duas semelhanças entre as principais dificuldades encontradas:

1. Falta de incentivos adequados para estimular os funcionários no alcance dos resultados desejados (seis citações, pelo menos uma por organização). Esses colaboradores apontaram o valor monetário não atrativo das comissões, a inexistência de um sistema recompensa para os resultados atingidos e a falta de meritocracia na escolha de ocupantes de cargos de comissão como fatores que desmotivam os funcionários na realização de seus trabalhos no âmbito dessa dimensão.

2. Lentidão do processo de mudança organizacional (duas citações). Esses respondentes identificam a visão estratégica e a organização como dinâmicas, porém relatam que o processo de mudança é muito lento. Tal fato deve-se, na opinião de um dos respondentes, ao tamanho da organização e pelas especificidades dos departamentos.

No Quadro 32, são apresentadas as soluções de melhorias apontadas pelos respondentes na dimensão Sustentabilidade do Gerenciamento Estratégico.

Quadro 32 - Soluções de melhorias na dimensão Sustentabilidade do Gerenciamento Estratégico

\begin{tabular}{|c|c|c|c|}
\hline Organização & Área & Respondente & Descrição \\
\hline $\mathrm{O} 1$ & $\mathrm{E}$ & R2 & $\begin{array}{l}\text { Intensificar a comunicação da estratégia dentro da } \\
\text { organização, demonstrando a importância de cada área } \\
\text { e servidor. }\end{array}$ \\
\hline $\mathrm{O} 1$ & $\mathrm{E}$ & R2 & $\begin{array}{l}\text { Criar um sistema de premiação por produtividade } \\
\text { baseada na gestão por resultados. }\end{array}$ \\
\hline $\mathrm{O} 1$ & $\mathrm{D}$ & R3 & $\begin{array}{l}\text { Os funcionários devem ter a remuneração vinculada } \\
\text { aos resultados alcançados. }\end{array}$ \\
\hline $\mathrm{O} 1$ & $\mathrm{D}$ & $\mathrm{R} 4$ & $\begin{array}{l}\text { As equipes devem ser integradas e o planejamento } \\
\text { estratégico deve permear todas as atividades realizadas } \\
\text { pela instituição. }\end{array}$ \\
\hline $\mathrm{O} 2$ & $\mathrm{E}$ & R1 & A comunicação interna deve ser intensificada. \\
\hline $\mathrm{O} 2$ & $\mathrm{E}$ & $\mathrm{R} 1$ & $\begin{array}{l}\text { Criação de uma área responsável pela gestão da } \\
\text { mudança organizacional. }\end{array}$ \\
\hline
\end{tabular}


Quadro 32 - Soluções de melhorias na dimensão Sustentabilidade do Gerenciamento

Estratégico (continuação)

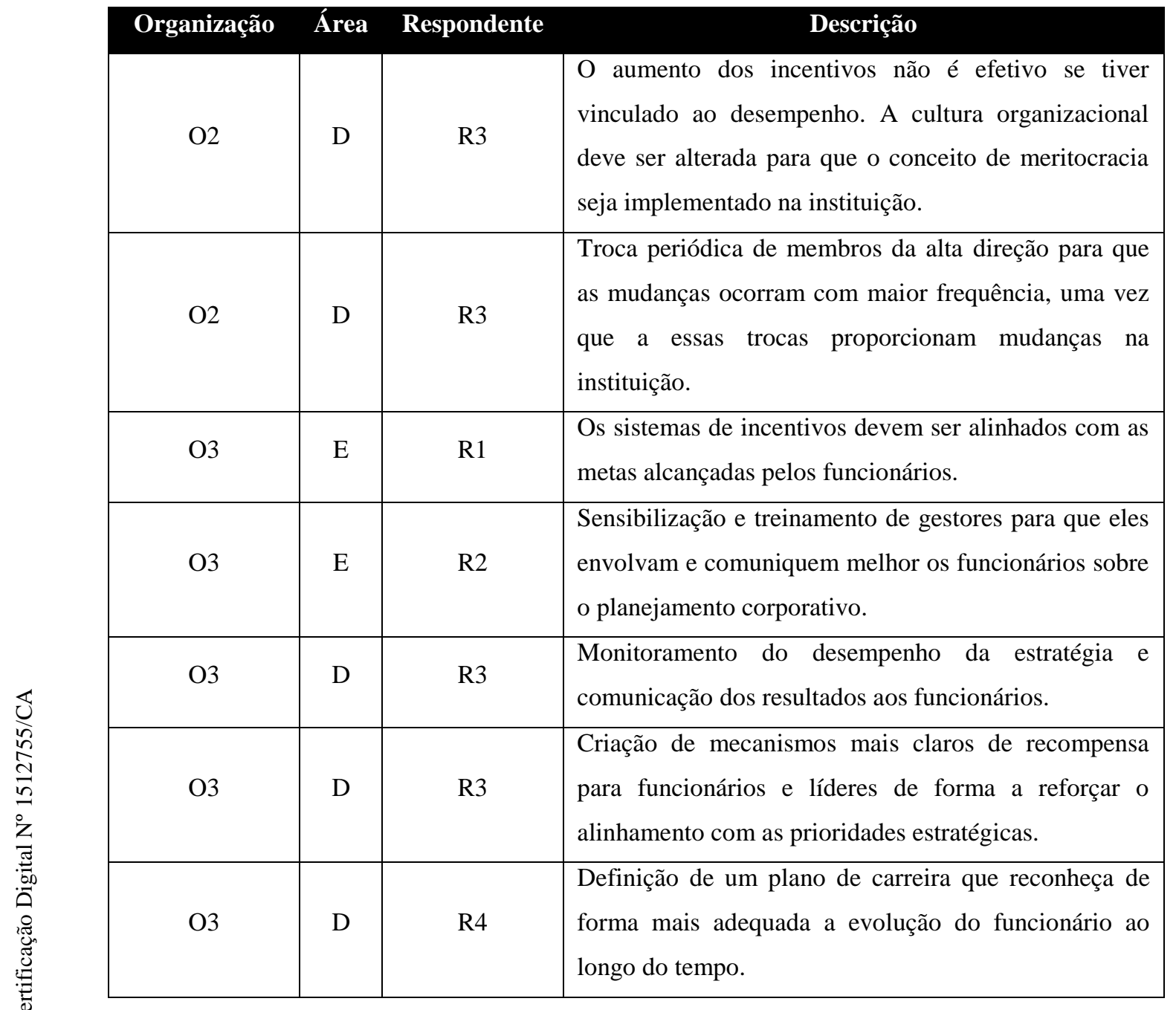

A partir da análise do Quadro 32, é possível observar duas semelhanças entre as soluções de melhorias apontadas pelos respondentes:

1. Criação de incentivos baseados em resultados (seis citações, pelo menos uma por organização). Esses colaboradores citaram a vinculação dos incentivos as metas individuais e organizacionais, a mudança da cultura organizacional para a efetiva implementação do conceito de meritocracia e a importância da criação de incentivos para reforçar o alinhamento dos colaboradores, inclusive dos próprios líderes, com as prioridades estratégicas.

2. Aprimoramento da comunicação interna no âmbito da estratégia organizacional, desde sua concepção e importância até o 
monitoramento e divulgação dos resultados aos colaboradores (quatro citações, pelo menos uma por organização).

\section{3.}

\section{Análise Comparativa dos Resultados em Gestão Estratégica}

De acordo com o $S M M M^{\mathrm{TM}}$, a análise conjunta das dimensões do modelo permite avaliar a maturidade da gestão estratégica das organizações. A partir dessa informação, a Tabela 9 foi gerada expondo os resultados alcançados pelas instituições, considerando as dimensões avaliadas, a área de atuação individual gestão estratégica (E) ou demais áreas (D) - e conjunta - geral (G) e, por fim, o nível de maturidade em gestão estratégica das organizações analisadas. Os níveis maturidades serão debatidos nos quadros seguintes, porém podem ser consultados no Quadro 15, levando-se em consideração as dimensões individualizadas, e no Quadro 16 considerando o processo de gestão estratégica de forma global.

Tabela 9 - Nível de maturidade em gestão estratégica

\begin{tabular}{|c|c|c|c|c|c|c|c|c|c|}
\hline & O1E & O1D & O1G & $\mathrm{O} 2 \mathrm{E}$ & $\mathrm{O} 2 \mathrm{D}$ & $\mathrm{O} 2 \mathrm{G}$ & $\mathrm{O} 3 \mathrm{E}$ & O3D & $\mathrm{O} 3 \mathrm{G}$ \\
\hline Liderança & 2,83 & 3,33 & 3,08 & 4,00 & 2,75 & 3,38 & 3,00 & 3,50 & 3,25 \\
\hline Cultura e Valores & 3,50 & 2,92 & 3,21 & 3,50 & 3,00 & 3,25 & 3,08 & 3,75 & 3,42 \\
\hline $\begin{array}{l}\text { Pensamento } \\
\text { Estratégico e } \\
\text { Planejamento } \\
\end{array}$ & 3,39 & 3,28 & 3,33 & 3,22 & 3,25 & 3,22 & 3,72 & 3,89 & 3,81 \\
\hline Alinhamento & 2,17 & 2,00 & 2,08 & 2,33 & 2,50 & 2,42 & 3,17 & 4,33 & 3,75 \\
\hline $\begin{array}{l}\text { Mensuração de } \\
\text { Desempenho }\end{array}$ & 2,50 & 2,64 & 2,57 & 3,00 & 4,07 & 3,54 & 4,64 & 2,36 & 3,50 \\
\hline $\begin{array}{l}\text { Gerenciamento de } \\
\text { Desempenho }\end{array}$ & 3,08 & 2,67 & 2,88 & 3,33 & 2,83 & 3,08 & 3,67 & 3,08 & 3,38 \\
\hline $\begin{array}{l}\text { Melhoria de } \\
\text { Processos }\end{array}$ & 3,86 & 3,80 & 3,79 & 3,50 & 4,43 & 3,96 & 3,50 & 3,00 & 3,25 \\
\hline $\begin{array}{l}\text { Sustentabilidade do } \\
\text { Gerenciamento } \\
\text { Estratégico }\end{array}$ & 3,21 & 2,93 & 3,07 & 3,14 & 2,86 & 3,00 & 3,64 & 2,93 & 3,29 \\
\hline $\begin{array}{c}\text { Nível de } \\
\text { Maturidade em } \\
\text { Gestão Estratégica }\end{array}$ & $\begin{array}{l}\text { Nível } 3 \\
(24,54)\end{array}$ & $\begin{array}{l}\text { Nível } 3 \\
(23,57)\end{array}$ & $\begin{array}{l}\text { Nível } 3 \\
(24,01)\end{array}$ & $\begin{array}{l}\text { Nível } 3 \\
(26,02)\end{array}$ & $\begin{array}{l}\text { Nível } 3 \\
(25,69)\end{array}$ & $\begin{array}{l}\text { Nível } 3 \\
(25,85)\end{array}$ & $\begin{array}{l}\text { Nível } 4 \\
(28,42)\end{array}$ & $\begin{array}{l}\text { Nível } 3 \\
(26,84)\end{array}$ & $\begin{array}{l}\text { Nível } 3 \\
(27,65)\end{array}$ \\
\hline
\end{tabular}

Com base na análise da Tabela 9, é possível verificar algumas diferenças entre os níveis de maturidade apontados pelos respondentes que atuam com gestão estratégica e os que atuam nas demais áreas da organização. Tais diferenças podem ter diversas causas, cabendo destacar: (1) os colaboradores das demais áreas tendem a avaliar a dimensão analisada a partir da visão departamental, enquanto os colaboradores da gestão estratégica, pela natureza de sua função, tendem a ter uma visão organizacional global; (2) não obstante o $S M M M^{\mathrm{TM}}$ ser passível de avaliação por todos na organização, os colaboradores que atuam na unidade de gestão estratégica tendem a ter maior conhecimento sobre os conceitos e técnicas 
utilizados no modelo, uma vez que esses fazem parte do processo de gerenciamento estratégico; (3) pelo envolvimento direto com a gestão estratégica, os respondentes dessa área podem ter uma visão mais otimista sobre a efetividade de suas ações no âmbito organizacional.

No que concerne aos respondentes que atuam na área de gestão estratégica, por meio da Tabela 9 e do Quadro 33, podem-se observar diferentes graus de maturidade nas dimensões e no processo de gestão estratégica. O Quadro 33 indica os níveis de maturidade encontrados no decorrer deste estudo quando considerados somente os respondentes da área de gestão estratégica.

Quadro 33 - Níveis de maturidade em gestão estratégica conforme os respondentes da unidade de gerenciamento estratégico

\begin{tabular}{|c|c|c|c|}
\hline & $\mathrm{O} 1$ & $\mathrm{O} 2$ & $\mathrm{O} 3$ \\
\hline Liderança & Nível 3 & Nível 4 & Nível 3 \\
\hline Cultura e Valores & Nível 4 & Nível 4 & Nível 3 \\
\hline $\begin{array}{l}\text { Pensamento Estratégico } \\
\text { e Planejamento }\end{array}$ & Nível 3 & Nível 3 & Nível 4 \\
\hline Alinhamento & Nível 2 & Nível 2 & Nível 3 \\
\hline $\begin{array}{l}\text { Mensuração de } \\
\text { Desempenho }\end{array}$ & Nível 3 & Nível 3 & Nível 5 \\
\hline $\begin{array}{l}\text { Gerenciamento de } \\
\text { Desempenho }\end{array}$ & Nível 3 & Nível 3 & Nível 4 \\
\hline Melhoria de Processos & Nível 4 & Nível 4 & Nível 4 \\
\hline $\begin{array}{l}\text { Sustentabilidade do } \\
\text { Gerenciamento } \\
\text { Estratégico }\end{array}$ & Nível 3 & Nível 3 & Nível 4 \\
\hline $\begin{array}{l}\text { Nível de Maturidade } \\
\text { em Gestão Estratégica }\end{array}$ & Nível 3 & Nível 3 & Nível 4 \\
\hline
\end{tabular}

Esses níveis, conforme apontados no Quadro 33, possibilitam a verificação dos pontos mais desenvolvidos e menos desenvolvidos das organizações, assim como apontam os níveis de maturidade em gestão estratégica indicados pelos respondentes dessa área. No âmbito das dimensões, observa-se a dimensão Melhoria de Processos como a mais desenvolvida e a dimensão Alinhamento como a menos desenvolvida, enquanto na análise do processo como um todo é possível observar que a organização 3 obteve o maior nível de maturidade. O $S M M M^{\mathrm{TM}}$, conforme descrito no Quadro 6, caracteriza as organizações pertencentes aos níveis de maturidade 3 e 4 no processo de gestão estratégica desta forma:

- Nível 3 - Estruturado e Pró-ativo: As organizações deste nível possuem estruturas e processos formais para implementar, de forma pró-ativa e 
abrangente, a gestão estratégica. Essa atividade ocorre de maneira regular e está sujeita a melhorias no decorrer do tempo. Os indicadores são parcialmente alinhados com a estratégia e a responsabilidade dos colaboradores é levada a sério.

- Nível 4 - Gerenciado e Focado: As organizações deste nível são guiadas pela estratégia. Os padrões e métodos organizacionais são amplamente utilizados para implementar a gestão estratégica. Os líderes envolvem formalmente os colaboradores no processo e a mensuração e a cultura de responsabilidade auxiliam no sucesso estratégico da organização.

Quanto aos respondentes que atuam nas demais áreas das organizações, por meio da Tabela 9 e do Quadro 34, também é possível observar diferentes graus de maturidade nas dimensões e no processo de gestão estratégica. O Quadro 34 indica os níveis de maturidade encontrados no decorrer deste estudo quando considerados apenas os respondentes das demais áreas das organizações.

Quadro 34 - Níveis de maturidade em gestão estratégica conforme os respondentes das demais áreas das organizações

\begin{tabular}{|c|c|c|c|}
\hline & $\mathrm{O} 1$ & $\mathrm{O} 2$ & $\mathrm{O} 3$ \\
\hline Liderança & Nível 3 & Nível 3 & Nível 4 \\
\hline Cultura e Valores & Nível 3 & Nível 3 & Nível 4 \\
\hline $\begin{array}{l}\text { Pensamento Estratégico } \\
\text { e Planejamento }\end{array}$ & Nível 3 & Nível 3 & Nível 4 \\
\hline Alinhamento & Nível 2 & Nível 3 & Nível 4 \\
\hline $\begin{array}{l}\text { Mensuração de } \\
\text { Desempenho }\end{array}$ & Nível 3 & Nível 4 & Nível 2 \\
\hline $\begin{array}{l}\text { Gerenciamento de } \\
\text { Desempenho }\end{array}$ & Nível 3 & Nível 3 & Nível 3 \\
\hline Melhoria de Processos & Nível 4 & Nível 4 & Nível 3 \\
\hline $\begin{array}{l}\text { Sustentabilidade do } \\
\text { Gerenciamento } \\
\text { Estratégico }\end{array}$ & Nível 3 & Nível 3 & Nível 3 \\
\hline $\begin{array}{l}\text { Nível de Maturidade } \\
\text { em Gestão Estratégica }\end{array}$ & Nível 3 & Nível 3 & Nível 3 \\
\hline
\end{tabular}

Os níveis, descritos no Quadro 34, possibilitam a verificação dos pontos mais desenvolvidos e menos desenvolvidos das organizações, assim como apontam os níveis de maturidade em gestão estratégica indicados pelos respondentes das demais áreas das organizações. No que diz respeito às dimensões, assim como constatado nas opiniões dos respondentes da área de gestão estratégica, a dimensão Melhoria de Processos aparece como a mais desenvolvida e a dimensão 
Alinhamento, nesse caso em conjunto com as dimensões Mensuração de Desempenho, Gerenciamento de Desempenho e Sustentabilidade do Gerenciamento Estratégico como as menos desenvolvidas. $\mathrm{Na}$ análise de maturidade do processo de gestão estratégica, todas as organizações posicionaram-se no terceiro nível de maturidade, nível esse descrito no Quadro 6 e na análise do Quadro 33.

Por fim, com base na análise da Tabela 9 e do Quadro 35, diferentes graus de maturidade nas dimensões e no processo de gestão estratégica podem ser observados quando são considerados os respondentes de forma conjunta. O Quadro 35 indica os níveis de maturidade encontrados no decorrer deste estudo considerando todos os respondentes.

Quadro 35 - Níveis de maturidade em gestão estratégica

\begin{tabular}{|c|c|c|c|}
\hline & O1 & $\mathrm{O} 2$ & $\mathrm{O3}$ \\
\hline Liderança & Nível 3 & Nível 3 & Nível 3 \\
\hline Cultura e Valores & Nível 3 & Nível 3 & Nível 3 \\
\hline $\begin{array}{l}\text { Pensamento Estratégico } \\
\text { e Planejamento }\end{array}$ & Nível 3 & Nível 3 & Nível 4 \\
\hline Alinhamento & Nível 2 & Nível 2 & Nível 4 \\
\hline $\begin{array}{l}\text { Mensuração de } \\
\text { Desempenho }\end{array}$ & Nível 3 & Nível 4 & Nível 4 \\
\hline $\begin{array}{l}\text { Gerenciamento de } \\
\text { Desempenho }\end{array}$ & Nível 3 & Nível 3 & Nível 3 \\
\hline Melhoria de Processos & Nível 4 & Nível 4 & Nível 3 \\
\hline $\begin{array}{l}\text { Sustentabilidade do } \\
\text { Gerenciamento } \\
\text { Estratégico }\end{array}$ & Nível 3 & Nível 3 & Nível 3 \\
\hline $\begin{array}{l}\text { Nível de Maturidade } \\
\text { em Gestão Estratégica }\end{array}$ & Nível 3 & Nível 3 & Nível 3 \\
\hline
\end{tabular}

Esses níveis, identificados no Quadro 35, assim como os Quadros 33 e 34, possibilitam a verificação dos pontos mais desenvolvidos e menos desenvolvidos das organizações, assim como apontam os níveis de maturidade em gestão estratégica. No âmbito das dimensões, observam-se as dimensões Mensuração de Desempenho e Melhoria de Processos como as mais desenvolvidas e a dimensão Alinhamento como a menos desenvolvida. Na análise de maturidade do processo de gestão estratégica, todas as organizações posicionaram-se no terceiro nível de maturidade, nível esse já descrito no Quadro 6 e na análise do Quadro 33.

A análise apresentada neste Capitulo trouxe diversas informações relevantes sobre as organizações estudadas, evidenciando o grau em que essas organizações 
seguem as boas práticas definidas pelo $S M M M^{\mathrm{TM}}$, os níveis de maturidade dessas organizações no processo de gestão estratégica e nas dimensões que o compõe, as principais dificuldades por elas enfrentadas e as sugestões dos respondentes para que suas instituições apresentem melhor desempenho. 


\section{5 \\ Conclusão}

A pesquisa realizada neste trabalho teve por objetivo avaliar o nível de maturidade em gestão estratégica das organizações públicas analisadas, bem como identificar e categorizar as principais dificuldades e as soluções de melhorias indicadas pelos participantes, sendo quatro por organização analisada, no âmbito das dimensões do processo de gerenciamento estratégico. Tais objetivos se justificam pela importância do processo de gestão estratégica para a administração e pela necessidade das organizações públicas adotarem uma gestão profissional e que atenda às demandas ambientais em constante mudança. Embora a literatura acadêmica focalize a avaliação de maturidade de processos e projetos ligados à área de TIC, a avaliação do grau de maturidade do processo de gestão estratégica é negligenciada ou até inexistente, se forem consideradas as organizações públicas como ponto focal de estudo.

Inicialmente, foram apresentadas a estrutura e as formas de trabalho da Administração Pública Brasileira, expondo seus principais conceitos, a evolução histórica dos modelos de gestão pública e o Modelo de Excelência em Gestão Pública (BRASIL, 2014). Em seguida, o processo de gestão estratégica foi analisado e descrito, tendo sido debatidos os conceitos de estratégica, planejamento estratégico, gestão estratégica e a avaliação de maturidade em relação à essa temática.

Complementou-se o Referencial Teórico com a apresentação do Strategic Management Maturity Model ${ }^{\mathrm{TM}}$ - SMMMTM. Tal modelo divide-se em oito dimensões (Liderança, Cultura e Valores, Pensamento Estratégico e Planejamento, Alinhamento, Mensuração de Desempenho, Gerenciamento de Desempenho, Melhoria de Processos e Sustentabilidade do Gerenciamento Estratégico) que juntas compõem o processo de gestão estratégica. Estabelece, também, cinco níveis de maturidade (Ad Hoc ou Estático, Reativo, Estruturado e Pró-ativo, Gerenciado e Focado e Melhoria Contínua). 
A escolha do $S M M M^{\mathrm{TM}}$ como base para o desenvolvimento deste estudo deveu-se às suas características de completude, simplicidade, aperfeiçoamento empírico constante e adaptabilidade.

O SMMMTM foi aqui adaptado e complementado, com vistas ao atingimento dos objetivos do estudo, para desenvolver uma análise mais minuciosa do processo de gestão estratégica, o $S M M M^{\mathrm{TM}}$ foi aqui adaptado e complementado. Na adaptação, as boas práticas indicadas no modelo foram transformadas em questões fechadas para que fossem passíveis de avaliação pelos participantes. Essa ação tornou necessária, também, a adaptação das formas de cálculo utilizadas pelo Modelo. Na complementação, foram incluídas questões abertas para que os respondentes pudessem citar quais dificuldades que mais os afligem e as soluções desses problemas para a melhora do desempenho de suas instituições.

Isso possibilitou o desenvolvimento do questionário de pesquisa composto por 51 questões fechadas, responsáveis pela avaliação do nível de maturidade das organizações públicas analisadas, e 16 questões abertas para que fossem apresentadas, pelos respondentes, as principais dificuldades e sugestões de melhoria no âmbito das organizações que atuam.

A partir das respostas desses questionários, foi realizada a avaliação do nível de maturidade em gestão estratégica tanto nas dimensões que compõem o processo de gestão estratégica como no processo como um todo. Além disso, foi possível verificar diferenças entre os níveis de maturidade indicados pelos colaboradores que atuam na área de gestão estratégica e os que atuam nas outras áreas e observar padrões para as principais dificuldades e soluções de melhoria apontadas pelos respondentes.

A avaliação de maturidade das organizações analisadas realizada neste estudo permitiu classificá-las como nível de maturidade 3 - Estruturado e Próativo - em uma escala de um a cinco, no processo de gestão estratégica, indicando desempenho mediano nesse processo. Além disso, com base na visão de todos os respondentes, observam-se as dimensões Mensuração de Desempenho e Melhoria de Processos como as mais desenvolvidas e a dimensão Alinhamento como a mais frágil no âmbito do processo estratégico.

O Modelo aplicado neste estudo, dentre outras contribuições, identificou alguns elementos necessários para o aprimoramento da gestão estratégica em 
organizações públicas: capacitação por parte dos lideres e dos servidores públicos em temas concernentes á gestão estratégica; remuneração vinculada aos objetivos institucionais; desenvolvimento de um conjunto de indicadores de desempenho vinculado as boas práticas; motivação por parte dos servidores para execução dos trabalhos ligados à gestão estratégica; ações de comunicação interna com o objetivo de envolver e conscientizar os funcionários; e atualização constante dos processos de trabalho.

Uma limitação do presente estudo pode ser identificada na impossibilidade de generalização dos dados no âmbito das organizações públicas analisadas, uma vez que a amostra utilizada é pequena em termos de relevância estatística. Além disso, o grande número de questões abertas e fechadas do questionário pode ter causado algum grau de fadiga nos respondentes, gerando menor aprofundamento e discussão das questões abordadas ao final do questionário.

Como forma de ultrapassar essas limitações, é aconselhável o desenvolvimento de um modelo menos sintético do que o $S M M M^{\mathrm{TM}}$, no que concerne ao questionário, porém menos extenso do que o desenvolvido nesta pesquisa, e sua aplicação em uma amostra significativamente relevante. Esse modelo possibilitaria uma análise mais aprofundada, porém não trabalhosa para os respondentes, constituindo uma ferramenta alternativa para os gestores e pesquisadores que desejassem avaliar o processo de gestão estratégica.

Esta pesquisa representa uma reflexão minuciosa sobre o grau de maturidade do processo de gestão estratégica, um aspecto importante do desempenho, principalmente para organizações públicas. Para que esse processo seja mais bem entendido e aprimorado, ressalta-se a importância de mais estudos que, à semelhança deste, busquem avaliá-lo em diversas organizações. 


\section{Referências bibliográficas}

ALEXANDRINO, M.; PAULO, V. Direito administrativo descomplicado. 23.ed. São Paulo: Método, 2008.

ANSOFF, H. I.; DECLERCK, R. P.; HAYES, B. L. Do planejamento estratégico à administração estratégica. São Paulo: Atlas, 1990.

ANSOFF, H. I.; MCDONNELL E. J. Implantando a administração estratégica. 2.ed. São Paulo: Atlas, 1993.

ASSOCIATION OF BUSINESS PROCESS MANAGEMENT PROFESSIONALS. Guia para o Gerenciamento de Processos de Negócio Corpo Comum de Conhecimento. 1.ed. Brasil, 2013.

BALANCED SCORECARD INSTITUTE. The Strategic Management Maturity Model ${ }^{\mathrm{TM}}$. North Carolina, 2010.

BALDAM, R. L.; VALLE, R.A.B.; PEREIRA, H.R.M.; HILST, S.M.; ABREU, M.P.; SOBRAL, A. Gerenciamento de processos de negócios: BPM Business Process Management. Vol.1. São Paulo: Érica, 2007.

BARNEY, J. B. Gaining and sustaining competitive advantage. 4th. New Jersey: Pearson Prentice Hall, 2014.

BAZZOTTI, C.; GARCIA, E. A importância do sistema de informação gerencial para tomada de decisões. Ciências Sociais aplicadas em revista, v. 6, n. 11, p. 1-18, 2006.

BETHLEM, A. Estratégia empresarial. Vol.4. São Paulo: Atlas, 2002.

BRASIL. Decreto no 4.418, de 11 de outubro de 2002. Aprova novo Estatuto Social da empresa pública Banco Nacional de Desenvolvimento Econômico e Social - BNDES. Diário Oficial da República Federativa do Brasil, Brasília, DF, 14 de outubro de 2002. Disponível em: < http://www2.camara.leg.br/legin/fed/decret/2002/decreto-4418-11-outubro2002-472019-norma-pe.html>. Acesso em 18 de Janeiro de 2017.

Decreto no 4.740, de 13 de junho de 2003. Aprova o Estatuto e o Quadro Demonstrativo dos Cargos em Comissão e Funções Gratificadas da Fundação Instituto Brasileiro de Geografia e Estatística - IBGE, e dá outras providências. Diário Oficial da República Federativa do Brasil, Brasília, DF, 16 de junho de 2003. Disponível em: < http://www.planalto.gov.br/ccivil_03/decreto/2003/D4740.htm>. Acesso em 18 de Janeiro de 2017.

Guia referencial para medição de desempenho e manual para construção de indicadores. Brasília: Ministério do Planejamento, 2009. Disponível em:

http://www.gespublica.gov.br/sites/default/files/documentos/guia_indicador es_jun2010.pdf >. Acesso em 16 de fevereiro de 2017. 
- Instrumento de Autoavaliação da Gestão Pública, Brasília: Ministério do Planejamento, 2016. Disponível em: $<$ http://gespublica.gov.br/sites/default/files/documentos/gagp250_pontos_novo.pdf>. Acesso em 20 de Maio de 2017.

Manual de Orientação para a Gestão do Desempenho, Brasília: Ministério do Planejamento, 2013. Disponível em: <http://www.planejamento.gov.br/assuntos/empresasestatais/publicacoes/151124_manual_orient_desemp.pdf >. Acesso em 19 de dezembro de 2016.

Modelo de Excelência em Gestão Pública, Brasília: Ministério do Planejamento, 2014.2 Disponível em: <http://gespublica.seplan.to.gov.br/index.php/downloads/doc_download/21 -modelo-de-excelencia-em-gestao-publica $\& \mathrm{~cd}=4 \& \mathrm{hl}=\mathrm{pt}$ $B R \& c t=c l n k \& g l=b r>$. Acesso em 22 de novembro de 2016.

Plano Diretor da Reforma do Aparelho do Estado, Brasília: Ministério da Administração Federal e da Reforma do Estado, 1995. Disponível em:<http://www.bresserpereira.org.br/Documents/MARE/Plano Diretor/planodiretor.pdf > . Acesso em 22 de novembro de 2016.

Portaria no 84.287, de 27 de fevereiro de 2015. Divulga o novo Regimento Interno do Banco Central do Brasil. Disponível em: < https://www.bcb.gov.br/Adm/Regimentolnterno/Regimentolnterno_2015.pd $f>$. Acesso em 18 de janeiro de 2017.

CAMARGOS, M.; DIAS, A. T. Estratégia, administração estratégica e estratégia corporativa: uma síntese teórica. Caderno de Pesquisas em Administração, São Paulo, v. 10, n. 1, p. 27-39, 2003.

CARVALHO FILHO, J. D. S. Manual de direito administrativo. 28.ed. Rio de Janeiro, Atlas, 2015.

CHOLEZ, H; GIRARD, F. Maturity assessment and process improvement for information security management in small and medium enterprises. Journal of Software: Evolution and Process, v. 26, n. 5, p. 496-503, 2014.

CORNELIU, B.; DIANA, R. N. Quality assessment of strategic management in organizations - a maturity model. Constanta Maritime University Annals, v. 14, n. 19, p. 259-262, 2013.

CRESWELL, J. W. Projeto de pesquisa: métodos qualitativo, quantitativo e misto. 3.ed. Porto Alegre: Artmed, 2010.

DE SOUZA, T. F.; GOMES, C. F. S. Assessment of Maturity in Project Management: A Bibliometric Study of Main Models. Procedia Computer Science, v. 55, p. 92-101, 2015.

DI PIETRO, M. S. Z. Direito administrativo. 27.ed. São Paulo, Atlas, 2014.

ESTRADA, R. J. S.; ALMEIDA, M. I. R. A eficiência e a eficácia da Gestão Estratégica: do Planejamento Estratégico à mudança organizacional. Revista de ciências da administração, v. 9, n. 19, p. 147-178, 2007. 
FERNANDES, B. H. R.; BERTON, L. H. Administração estratégica: da competência empreendedora à avaliação de desempenho. 2.ed. São Paulo: Saraiva, 2012.

FERREIRA, H.; CASSIOLATO, M.; GONZALEZ, R. Uma experiência de desenvolvimento metodológico para avaliação de programas: 0 modelo lógico do programa segundo tempo. Texto para discussão. Brasília: IPEA, 2009.

FLEURY, M. T. L. Estórias, mitos, heróis: cultura organizacional e relações do trabalho. Revista de administração de empresas, v. 27, n. 4, p. 7-18, 1987.

FREDRICKSON, J. W. The Comprehensiveness Strategic decision processes: Extension, observations, future directions. Academy of Management Journal, v. 27, n. 3, p. 445-466, 1984.

GABRYELCZYK, R. Does Grade Level Matter for the Assessment of Business Process Management Maturity? Naše gospodarstvo/Our economy, v. 62, n. 2, p. 3-11, 2016.

GHEMAWAT, P. A. estratégia e o cenário dos negócios: texto e casos. Porto Alegre: Bookman, 2000.

GHOSH, A. K. Employee empowerment: a strategic tool to obtain sustainable competitive advantage. International Journal of Management, v. 30, n. 3, p. 95, 2013.

GOMES, E. G. M. Gestão por Resultados e eficiência na Administração Pública: uma análise à luz da experiência de Minas Gerais. São Paulo, 2009. 187f. Tese (Doutorado) - Fundação Getúlio Vargas, Escola de Administração de Empresas de São Paulo.

GRANT, K. P.; PENNYPACKER, J. S. Project management maturity: An assessment of project management capabilities among and between selected industries. IEEE Transactions on engineering management, $v$. 53, n. 1, p. 59-68, 2006.

HAMMER, M. The process audit. Harvard business review, v. 85, n. 4, p. 111, 2007.

HAYES, J. The theory and practice of change management. 1.ed. Londres: Palgrave Macmillan, 2002.

HENDERSON, B. D. The origin of strategy. Harvard business review, v. 67, n. 6, p. 139-143, 1989.

HITT, M. A.; IRELAND, R. D.; HOSKISSON, R. E. Administração estratégica. 2.ed. São Paulo: Cengage Learning, 2011.

JONES, J.; AGUIRRE, D.; CALDERONE, M. 10 Principles of Change Management: tools and techniques to help companies transform quickly. Strategy+business: Booz, Allen \& Hamilton, 2004.

KAPLAN, R. S.; NORTON, D. P. A estratégia em ação: balanced scorecard. 12.ed. Rio de Janeiro: Campus, 2002. 
KUNDLER, J. Maturity Assessment of Maintenance Processes at ATCService Providers. Transport and Telecommunication, v. 13, n. 1, p. 1832, 2012.

LACOMBE, B. M. B.; ALBUQUERQUE, L. G. Avaliação e mensuração de resultados em gestão de pessoas: um estudo com as maiores empresas instaladas no Brasil. Revista de Administração, v. 43, n. 1, p. 5-16, 2008.

LANE, J. E.; WALLIS, J. Strategic management and public leadership. Public Management Review, v.11, n.1, p. 101-120, 2009.

LINDBLOM, C. E. The science of muddling through. Public Administration Review, v. 19, p. 79-88, 1959.

LOCKAMY III, A.; MCCORMACK, K. The development of a supply chain management process maturity model using the concepts of business process orientation. Supply Chain Management: An International Journal, v. 9, n. 4, p. 272-278, 2004.

MELO, M. A. C. O processo de planejamento e as inovações tecnológicas e sociais: uma perspectiva sócio-ecológica. Anais do 5 Seminário de Modernização Tecnológica Periférica, 1997.

MELO, M. A. C. O Planejamento para Acelerar o Processo. Revista do Serviço Público, v.14, n. 5, p. 43-47, 1987.

MERCHANT, K. A. Measuring general managers' performances: Market, accounting and combination-of-measures systems. Accounting, Auditing \& Accountability Journal, v. 19, n. 6, p. 893-917, 2006.

MINTZBERG, H.; WATERS, J. A. Of strategies, deliberate and emergent. Strategic Management Journal, v. 6, n. 3, p. 257-272, 1985.

MUHR, Thomas. Atlas/ti-a prototype for the support of text interpretation. Qualitative sociology, v. 14, n. 4, p. 349-371, 1991.

OBJECT MANAGEMENT GROUP. Business Process Model and Notation. Needham, v.2.0, 2011.

OSLAND, J. S. Building Comunity through Change. In: The Blackwell Handbook of Global Management: A Guide to Managing Complexity. 1.ed. United Kingdom: Blackwell Publishing, p. 134-151. 2004.

PECI, A.; PIERANTI, O. P.; RODRIGUES, S. Governança e New Public Management: convergências e contradições no contexto brasileiro. Organizações \& Sociedade, v. 15, n. 46, p. 39-55, 2008.

PRIETO, V. C.; Carvalho, M. M. D.; Fischmann, A. A. Análise comparativa de modelos de alinhamento estratégico. Produção, v. 19, n. 2, p. 317331,2009

RAD, P. F.; LEVIN, G. Project management maturity assessment. AACE International Transactions, p. PM61, 2006.

RODRIGUES, C. H. R.; SANTOS, F. C. A. Empowerment: ciclo de implementação, dimensões e tipologia. Gestão \& Produção, v. 8, n. 3, p. 237-249, 2001. 
ROTHAERMEL, F. T. Strategic management. 2nd. New York: McGrawHill, 2015.

SANTOS, A. B. A. Um modelo integrador para formulação de estratégias múltiplas: contribuição da análise prospectiva. Rio de Janeiro, 2011. 264f. Tese (Doutorado) - Pontifícia Universidade Católica do Rio de Janeiro, Departamento de Administração.

SANTOS, N. M.; SANTOS, F. M.T.; LADEIRA, M. B.; OLIVEIRA, M.P.V. Modelos de maturidade em processos: um estudo exploratório. $\mathbf{X X X}$ Encontro Nacional de Engenharia de Produção, 2010.

SCHEIN, E. H. Organizational culture and leadership. 3rd. San Francisco: John Wiley \& Sons, 2004.

SENGE, P. M. A Quinta disciplina: arte e prática da organização que aprende. 12.ed. São Paulo: Best Seller, 2002.

SEREK, R. Service Quality and Process Maturity Assessment. Journal of Competitiveness, v. 5, n. 4, p.43-56, 2013.

SERTEK, P.; GUINDANI, R. A.; MARTINS, T. S. Administração e planejamento estratégico. 20.ed. Curitiba: Editora lbpex, 2007.

SILVA, E. A.; PEREIRA, J. R.; ALCANTARA, V. C. Interfaces epistemológicas sobre administração pública, institucionalismo e capital social. Cad. EBAPE.BR, vol.10, n.1, pp. 20-39, 2012.

SIQUEIRA, J. O Modelo de Maturidade de Processos: como maximizar o retorno dos investimentos em melhoria da qualidade e produtividade. Instituto Brasileiro de Qualidade Nuclear, 2005.

TRIST, E. L. Action research and adaptive planning. In: Experimenting with organizational life. Springer, p. 223-236,1976.

VERGARA, S. C. Métodos de pesquisa em administração. 5.ed. São Paulo: Atlas, 2012.

VOLBERDA, H. W. Crise em estratégia: fragmentação, integração ou síntese. Revista de Administração de Empresas - RAE, v. 44, n. 4, p. 32-43, 2004.

WRIGHT, P.; KROLL, M. J.; PARNELL, J. Administração estratégica: conceitos. 1.ed. São Paulo: Atlas, 2000.

YIN, R. K. Case Study Research: Design and Methods. 3rd. California: Sage, 2003. 
Anexo

\section{Anexo A - Tradução do Questionário do Strategic Management Maturity Model ${ }^{\mathrm{TM}}$}

\begin{tabular}{|c|c|c|c|c|c|}
\hline & $\begin{array}{c}\text { Nível 1: } \\
\text { Ad Hoc e Estático }\end{array}$ & $\begin{array}{l}\text { Nível 2: } \\
\text { Reativo }\end{array}$ & $\begin{array}{l}\text { Nível 3: } \\
\text { Estruturado e Pró-ativo }\end{array}$ & $\begin{array}{c}\text { Nível 4: } \\
\text { Gerenciado e Focado }\end{array}$ & $\begin{array}{c}\text { Nível 5: } \\
\text { Melhoria Contínua }\end{array}$ \\
\hline Liderança & $\begin{array}{l}\text { Os líderes são ditatoriais, } \\
\text { preocupando-se } \\
\text { exclusivamente com as } \\
\text { atividades de comando e } \\
\text { controle. }\end{array}$ & $\begin{array}{l}\text { Os líderes são ditatoriais, } \\
\text { mas preocupa-se } \\
\text { esporadicamente em dar } \\
\text { feedbacks. }\end{array}$ & $\begin{array}{l}\text { Os líderes se engajam } \\
\text { apenas com seus } \\
\text { reportantes diretos, mas } \\
\text { modelam os valores e } \\
\text { comportamentos desejados. }\end{array}$ & $\begin{array}{l}\text { Os líderes empoderam os } \\
\text { funcionários, buscando seus } \\
\text { engajamentos contínuos. }\end{array}$ & $\begin{array}{l}\text { Os líderes e os funcionários } \\
\text { estão completamente } \\
\text { engajados, utilizando o } \\
\text { diálogo contínuo baseado } \\
\text { em uma cultura de equipe. }\end{array}$ \\
\hline Cultura e Valores & $\begin{array}{l}\text { A visão e os valores são } \\
\text { indefinidos ou não são } \\
\text { compartilhados. }\end{array}$ & $\begin{array}{l}\text { A visão e os valores são } \\
\text { publicados, mas não são } \\
\text { vividos. }\end{array}$ & $\begin{array}{l}\text { A visão e os valores são } \\
\text { comunicados e entendidos. }\end{array}$ & $\begin{array}{l}\text { A visão e os valores são } \\
\text { desenvolvidos de forma } \\
\text { colaborativa. }\end{array}$ & $\begin{array}{l}\text { A visão e os valores são } \\
\text { completamente integrados à } \\
\text { cultura organizacional. }\end{array}$ \\
\hline $\begin{array}{c}\text { Pensamento Estratégico e } \\
\text { Planejamento }\end{array}$ & $\begin{array}{l}\text { Não existe planejamento } \\
\text { estratégico na instituição e } \\
\text { nenhum objetivo é } \\
\text { definido. }\end{array}$ & $\begin{array}{l}\text { O planejamento estratégico } \\
\text { é responsabilidade de uma } \\
\text { pequena equipe e ordenado } \\
\text { à toda organização. }\end{array}$ & $\begin{array}{l}\text { Um processo de } \\
\text { planejamento estruturado e } \\
\text { aberto envolve diversos } \\
\text { funcionários dentro da } \\
\text { organização de tempos em } \\
\text { tempos. }\end{array}$ & $\begin{array}{l}\text { Planos são desenvolvidos e } \\
\text { revisados diariamente por } \\
\text { uma equipe treinada e } \\
\text { multidisciplinar. }\end{array}$ & $\begin{array}{l}\text { Estratégia guia as decisões } \\
\text { organizacionais críticas e } \\
\text { um processo de } \\
\text { planejamento é sustentado. }\end{array}$ \\
\hline
\end{tabular}




\begin{tabular}{|c|c|c|c|c|c|}
\hline & $\begin{array}{c}\text { Nível 1: } \\
\text { Ad Hoc e Estático }\end{array}$ & $\begin{array}{l}\text { Nível 2: } \\
\text { Reativo }\end{array}$ & $\begin{array}{c}\text { Nível 3: } \\
\text { Estruturado e Pró-ativo }\end{array}$ & $\begin{array}{c}\text { Nível 4: } \\
\text { Gerenciado e Focado }\end{array}$ & $\begin{array}{c}\text { Nível 5: } \\
\text { Melhoria Contínua }\end{array}$ \\
\hline Alinhamento & $\begin{array}{l}\text { O trabalho é estreitamente } \\
\text { baseado na estrutura } \\
\text { organizacional, com } \\
\text { pequenas contribuições dos } \\
\text { consumidores. }\end{array}$ & $\begin{array}{l}\text { As necessidades dos } \\
\text { consumidores e o feedback } \\
\text { começam a influenciar nas } \\
\text { decisões, tornando-as mais } \\
\text { alinhadas. }\end{array}$ & $\begin{array}{l}\text { Os funcionários conhecem } \\
\text { seus consumidores e } \\
\text { alinham as estratégias a } \\
\text { suas necessidades. }\end{array}$ & $\begin{array}{l}\text { Visão, necessidades dos } \\
\text { consumidores, estratégia e } \\
\text { sistemas de premiação e } \\
\text { reconhecimento dos } \\
\text { funcionários estão alinhados. }\end{array}$ & $\begin{array}{l}\text { Todas as estruturas e } \\
\text { sistemas são alinhados com } \\
\text { a estratégia. Além disso, o } \\
\text { alinhamento organizacional } \\
\text { é continuamente } \\
\text { melhorado. }\end{array}$ \\
\hline $\begin{array}{c}\text { Mensuração de } \\
\text { Desempenho }\end{array}$ & $\begin{array}{l}\text { Nenhum indicador, ou } \\
\text { apenas indicadores de } \\
\text { desempenho ad hoc são } \\
\text { utilizados. }\end{array}$ & $\begin{array}{l}\text { Indicadores de desempenho } \\
\text { são utilizados } \\
\text { rotineiramente, mas na } \\
\text { maioria das vezes com foco } \\
\text { em aspectos operacionais. }\end{array}$ & $\begin{array}{l}\text { Indicadores de desempenho } \\
\text { estratégico são utilizados, } \\
\text { cobrindo a maioria dos } \\
\text { objetivos estratégicos. }\end{array}$ & $\begin{array}{l}\text { Indicadores estratégicos são } \\
\text { amplamente utilizados para } \\
\text { melhorar o foco e o } \\
\text { desempenho, guiando } \\
\text { decisões ligadas ao } \\
\text { orçamento. }\end{array}$ & $\begin{array}{l}\text { Indicadores estratégicos são } \\
\text { abrangentemente utilizados } \\
\text { e rotineiramente revisados } \\
\text { com foco na melhoria } \\
\text { contínua. }\end{array}$ \\
\hline $\begin{array}{l}\text { Gerenciamento de } \\
\text { Desempenho }\end{array}$ & $\begin{array}{l}\text { Nenhuma ênfase é dada na } \\
\text { utilização de indicadores } \\
\text { como um critério para gerir } \\
\text { a organização. }\end{array}$ & $\begin{array}{l}\text { Análises de desempenho } \\
\text { são solicitadas, porém não } \\
\text { são levadas à sério. Não } \\
\text { existe responsabilidade } \\
\text { sobre o desempenho } \\
\text { aferido. }\end{array}$ & $\begin{array}{l}\text { Os indicadores são } \\
\text { alocados a 'donos', sendo o } \\
\text { desempenho acompanhado } \\
\text { no nível individual e } \\
\text { organizacional. }\end{array}$ & $\begin{array}{l}\text { Os ‘donos’ são } \\
\text { responsabilizados e o } \\
\text { desempenho é gerido em } \\
\text { todos os níveis. }\end{array}$ & $\begin{array}{l}\text { A medição e a } \\
\text { responsabilidade fazem } \\
\text { parte da cultura } \\
\text { organizacional, sendo as } \\
\text { decisões baseadas em } \\
\text { evidências. }\end{array}$ \\
\hline
\end{tabular}




\begin{tabular}{|c|c|c|c|c|c|}
\hline & $\begin{array}{c}\text { Nível 1: } \\
\text { Ad Hoc e Estático }\end{array}$ & $\begin{array}{l}\text { Nível 2: } \\
\text { Reativo }\end{array}$ & $\begin{array}{c}\text { Nível 3: } \\
\text { Estruturado e Pró-ativo }\end{array}$ & $\begin{array}{c}\text { Nível 4: } \\
\text { Gerenciado e Focado }\end{array}$ & $\begin{array}{c}\text { Nível 5: } \\
\text { Melhoria Contínua }\end{array}$ \\
\hline Melhoria de Processos & $\begin{array}{l}\text { Os processos não são } \\
\text { documentados e são ad hoc } \\
\text { com duplicações e atrasos. }\end{array}$ & $\begin{array}{l}\text { Apenas alguns processos } \\
\text { chaves são documentados e } \\
\text { alguns modelos de melhoria } \\
\text { de processos são } \\
\text { introduzidos. }\end{array}$ & $\begin{array}{l}\text { Todos os processos chaves } \\
\text { são identificados e } \\
\text { documentados, sendo a } \\
\text { estratégia a guia para } \\
\text { iniciativas de melhoria nos } \\
\text { processos. }\end{array}$ & $\begin{array}{l}\text { Todos os processos chaves } \\
\text { da organização são } \\
\text { acompanhados e melhorados } \\
\text { continuamente. Ideias novas } \\
\text { para a melhoria dos } \\
\text { processos são aceitas. }\end{array}$ & $\begin{array}{l}\text { Os funcionários são } \\
\text { empoderados e treinados. } \\
\text { Além disso, existe um } \\
\text { processo formal para a } \\
\text { melhoria contínua dos } \\
\text { processos de gestão. }\end{array}$ \\
\hline $\begin{array}{l}\text { Sustentabilidade do } \\
\text { Gerenciamento } \\
\text { Estratégico }\end{array}$ & $\begin{array}{l}\text { Falta de estrutura e líderes } \\
\text { mobilizadores atuando em } \\
\text { tarefas de curto prazo. }\end{array}$ & $\begin{array}{l}\text { Os líderes mobilizadores } \\
\text { são identificados. }\end{array}$ & $\begin{array}{l}\text { A organização formal está } \\
\text { estruturada para manter o } \\
\text { foco na estratégia. }\end{array}$ & $\begin{array}{l}\text { A organização possui uma } \\
\text { unidade de gestão estratégica } \\
\text { ou equivalente. }\end{array}$ & $\begin{array}{l}\text { O pensamento e a gestão } \\
\text { estratégica estão enraizados } \\
\text { na cultura organizacional. }\end{array}$ \\
\hline
\end{tabular}




\section{Anexo B - Transcrição de E-mail enviado por Howard Rohm}

Hi Alan, I'm Howard Rohm with the Balanced Scorecard Institute.

I developed the Strategic Management Maturity Model (SMMMTM) (TM) after learning about an earlier model used in the computer software world. In the 1980's a model called the Capability Maturity Model (CMM) was created after studying data collected from organizations that contracted with the U.S. Department of Defense, who funded the research. The term "maturity" relates to the degree of formality and optimization of processes, from ad hoc practices, to formally defined steps, to managed result metrics, to active optimization of the processes. The model's aim was to improve existing software development processes being used by government contractors.

Using the basic logic of the model, I changed the focus to measure strategy management effectiveness levels and dimensions of maturity based on what we have observed in over 200 consulting and training engagements in 40 countries worldwide over the past 15 years. We've refined the model over the years to help organizations create a baseline they can use to track progress of their performance management journey as they implement various performance change initiatives in their organizations.

Regards,

Howard Rohm

President and CEO

Balanced Scorecard Institute

A Strategy Management Group company

Member, Board of Directors, ASP

www.balancedscorecard.org

Office: +1919 460-8180 


\section{Apêndice}

\section{Apêndice A - Questionário de Pesquisa}

\section{Informações Gerais}

\begin{tabular}{|l|l|}
\hline Nome: & \\
\hline Organização: & \\
\hline Cargo: & \\
\hline Formação: & \\
\hline
\end{tabular}

Em relação a sua organização, favor responda:

Informações sobre o processo de gestão estratégica

\begin{tabular}{|c|c|c|c|c|c|c|c|}
\hline & 1 - Discordo totalmente & $\mathrm{c}$ & & & & & \\
\hline & $\begin{array}{r}\text { Não concordo, nem discordo } 4 \text { - Concordo parcia } \\
\text { totalmente } 6 \text { - Não tenho como av }\end{array}$ & $\begin{array}{l}\text { Imen } \\
\text { lliar }\end{array}$ & & & Co & cor & \\
\hline & LIDERANÇA & & & & & & \\
\hline 1 & $\begin{array}{l}\text { Os líderes definem uma visão de futuro clara e } \\
\text { consistente sobre a organização. }\end{array}$ & 1 & 2 & 3 & 4 & 5 & 6 \\
\hline 2 & $\begin{array}{l}\text { Os líderes são pró-ativos na preparação da } \\
\text { organização para o futuro. }\end{array}$ & 1 & 2 & 3 & 4 & 5 & 6 \\
\hline 3 & $\begin{array}{l}\text { Os líderes são acessíveis e engajados para garantir o } \\
\text { entendimento, por parte dos funcionários, de uma } \\
\text { visão comum e para que eles consigam traduzi-la } \\
\text { em termos relevantes para a execução dos trabalhos. }\end{array}$ & 1 & 2 & 3 & 4 & 5 & 6 \\
\hline 4 & $\begin{array}{l}\text { Os líderes são consistentes entre o que dizem e o } \\
\text { que fazem no que diz respeito aos valores, à ética e } \\
\text { às políticas da organização. }\end{array}$ & 1 & 2 & 3 & 4 & 5 & 6 \\
\hline
\end{tabular}




\begin{tabular}{|c|l|c|c|c|c|c|c|}
\hline 5 & $\begin{array}{l}\text { Os líderes não microgerenciam, preferem confiar e } \\
\text { encorajar os funcionários a contribuir com ideias e } \\
\text { estimular o crescimento em suas carreiras. }\end{array}$ & 1 & 2 & 4 & 5 & 6 \\
\hline 6 & $\begin{array}{l}\text { Os líderes interagem e trabalham lado a lado com os } \\
\text { funcionários, estimulando o trabalho em equipe. }\end{array}$ & 1 & 2 & 3 & 4 & 5 & 6 \\
\hline
\end{tabular}

Quais são as dificuldades que sua organização enfrenta nessa dimensão?

\section{Quais seriam suas sugestões para que sua organização melhorasse o desempenho nessa dimensão?}

\begin{tabular}{|c|c|c|c|c|c|c|c|}
\hline \multicolumn{8}{|c|}{1 - Discordo totalmente 2 -Discordo parcialmente } \\
\hline \multicolumn{4}{|c|}{$\begin{array}{r}3 \text { - Não concordo, nem discordo } 4 \text { - Concordo parcialmente } \\
\text { totalmente } 6 \text { - Não tenho como avaliar }\end{array}$} & \multicolumn{4}{|c|}{5 - Concordo } \\
\hline \multicolumn{8}{|c|}{ CULTURA E VALORES } \\
\hline 1 & $\begin{array}{l}\text { A liderança aplica corretamente os princípios e } \\
\text { práticas de gestão da mudança. }\end{array}$ & 1 & 2 & 3 & 4 & 5 & 6 \\
\hline 2 & Os funcionários se sentem identificados com a visão & 1 & 2 & 3 & 4 & 5 & 6 \\
\hline
\end{tabular}




\begin{tabular}{|c|l|l|l|l|l|l|l|}
\hline & e com os valores organizacionais. & & & & & \\
\hline 3 & $\begin{array}{l}\text { Os funcionários participam ativamente da } \\
\text { construção da cultura organizacional e das formas } \\
\text { de trabalho. }\end{array}$ & 2 & 3 & 4 & 5 & 6 \\
\hline 4 & $\begin{array}{l}\text { Os funcionários se comunicam com confiança, } \\
\text { transparência e liberdade para interagir com } \\
\text { franqueza, em oposição a uma cultura de medo e de } \\
\text { negação. }\end{array}$ & 2 & 3 & 4 & 5 & 6 \\
\hline 5 & $\begin{array}{l}\text { Os funcionários possuem flexibilidade e vontade de } \\
\text { mudar para alinhar a novas prioridades estratégicas. }\end{array}$ & 1 & 2 & 3 & 4 & 5 & 6 \\
\hline 6 & $\begin{array}{l}\text { Os funcionários têm consciência dos valores e } \\
\text { políticas declaradas, aderindo a eles de forma } \\
\text { consistente. }\end{array}$ & 1 & 2 & 3 & 4 & 5 & 6 \\
\hline
\end{tabular}

Quais são as dificuldades que sua organização enfrenta nessa dimensão?

Quais seriam suas sugestões para que sua organização melhorasse o desempenho nessa dimensão? 


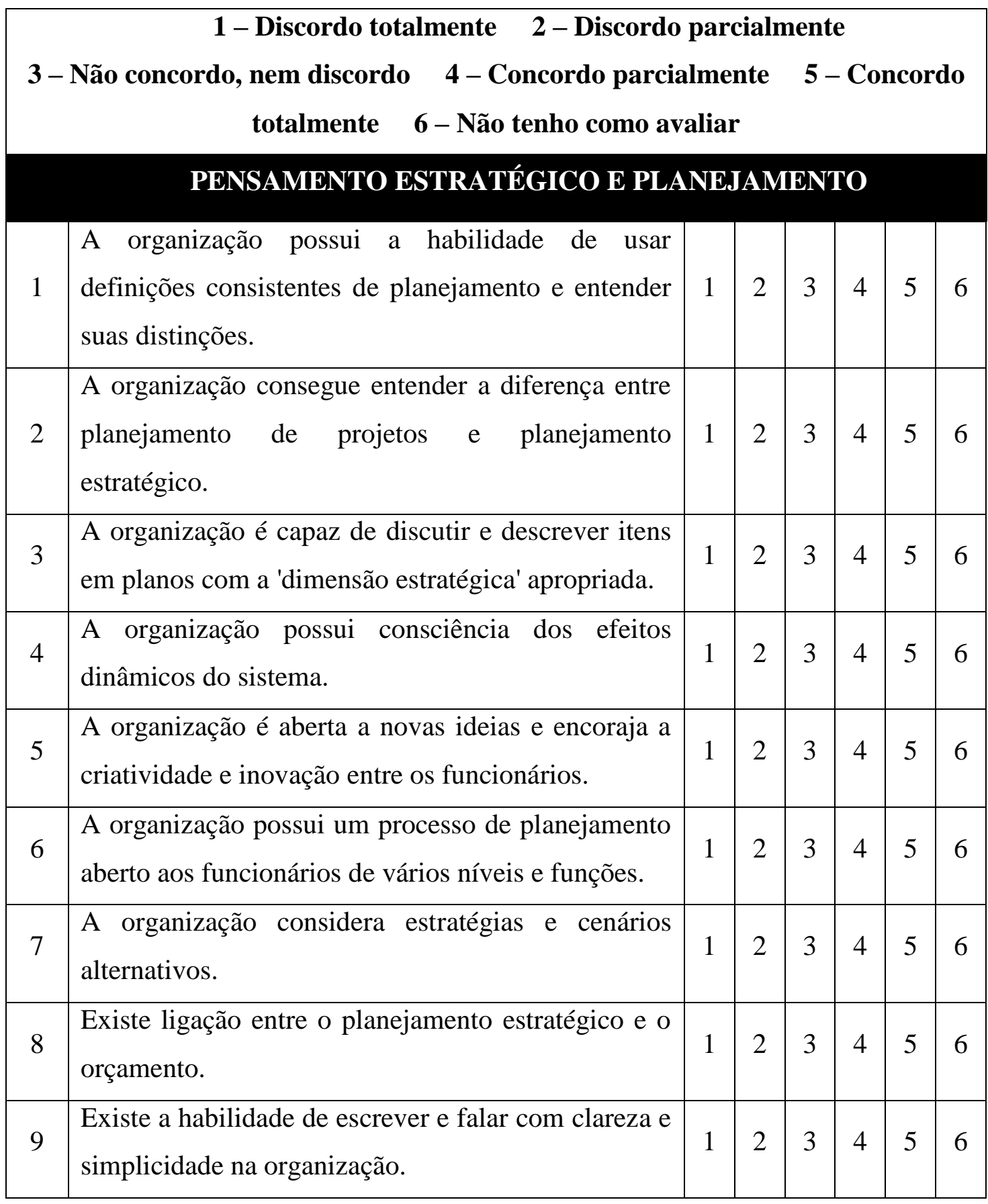

Quais são as dificuldades que sua organização enfrenta nessa dimensão? 
Quais seriam suas sugestões para que sua organização melhorasse o desempenho nessa dimensão?

\begin{tabular}{|c|c|c|c|c|c|c|c|}
\hline \multicolumn{8}{|c|}{1 -Discordo totalmente 2 -Discordo parcialmente } \\
\hline \multicolumn{4}{|c|}{$\begin{array}{r}3 \text { - Não concordo, nem discordo } 4 \text { - Concordo parcialmente } \\
\text { totalmente } 6 \text { - Não tenho como avaliar }\end{array}$} & \multicolumn{4}{|c|}{5 - Concordo } \\
\hline \multicolumn{8}{|c|}{ ALINHAMENTO } \\
\hline 1 & $\begin{array}{l}\text { Os funcionários de todos os níveis da organização } \\
\text { são motivados por uma visão e pela estratégia } \\
\text { comuns. }\end{array}$ & 1 & 2 & 3 & 4 & 5 & 6 \\
\hline 2 & $\begin{array}{l}\text { Os funcionários entendem que dar suporte à } \\
\text { estratégia é sua função. }\end{array}$ & 1 & 2 & 3 & 4 & 5 & 6 \\
\hline 3 & $\begin{array}{l}\text { Os funcionários são auto-motivados, não atuando } \\
\text { apenas pela obediência as normas. }\end{array}$ & 1 & 2 & 3 & 4 & 5 & 6 \\
\hline
\end{tabular}

Quais são as dificuldades que sua organização enfrenta nessa dimensão? 
Quais seriam suas sugestões para que sua organização melhorasse o desempenho nessa dimensão?

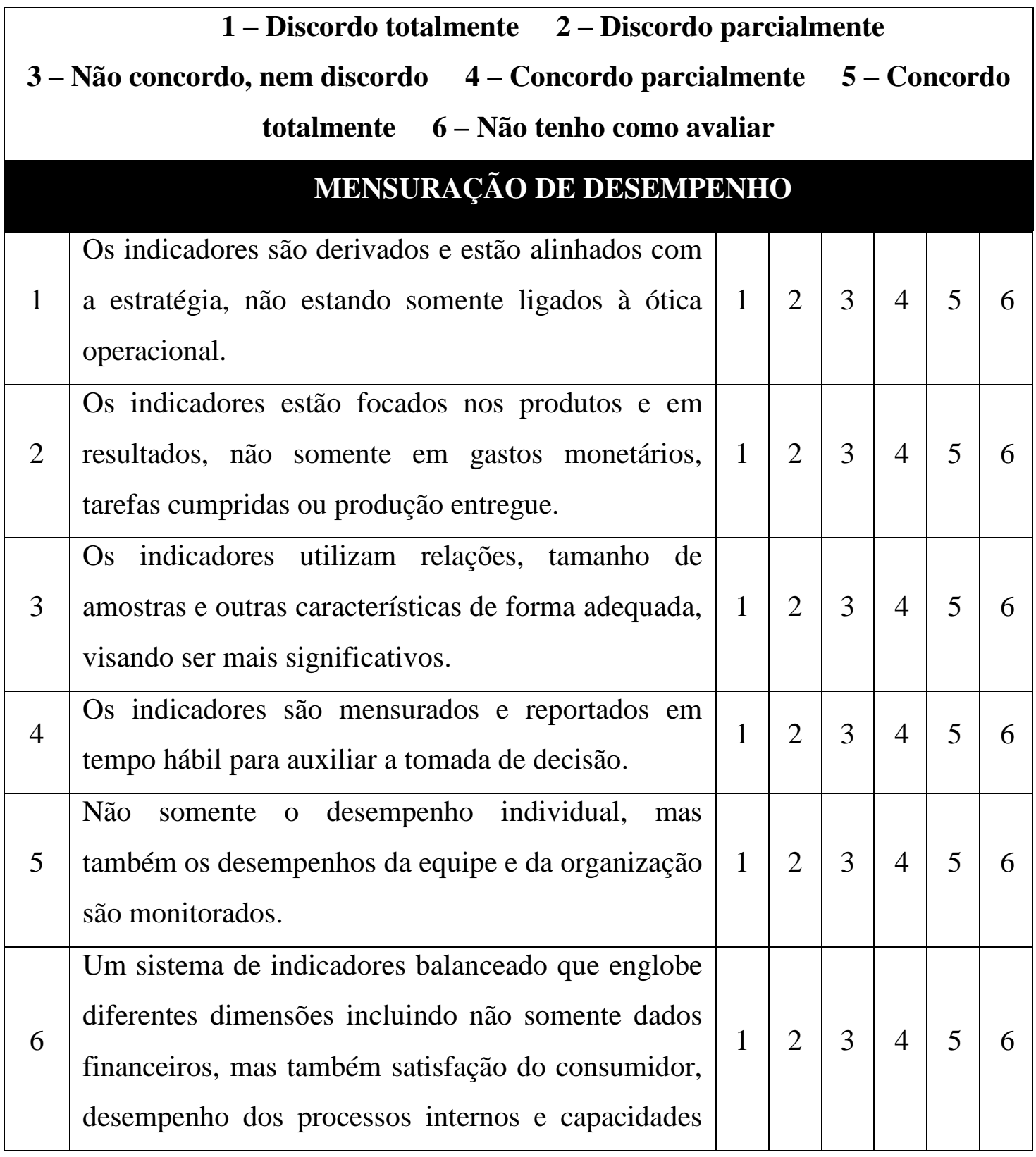




\begin{tabular}{|l|l|l|l|l|l|l|l|}
\hline & da organização é utilizado. & & & & & & \\
\hline 7 & $\begin{array}{l}\text { A organização possui sistemas de Tecnologia da } \\
\text { Informação em rede para a coleta e distribuição dos } \\
\text { indicadores de desempenho que permitem aos } \\
\text { usuários verem os dados necessários em tempo hábil } \\
\text { para a tomada de decisão. }\end{array}$ & 1 & 2 & 4 & 5 & 6 \\
\hline
\end{tabular}

Quais são as dificuldades que sua organização enfrenta nessa dimensão?

Quais seriam suas sugestões para que sua organização melhorasse o desempenho nessa dimensão? 


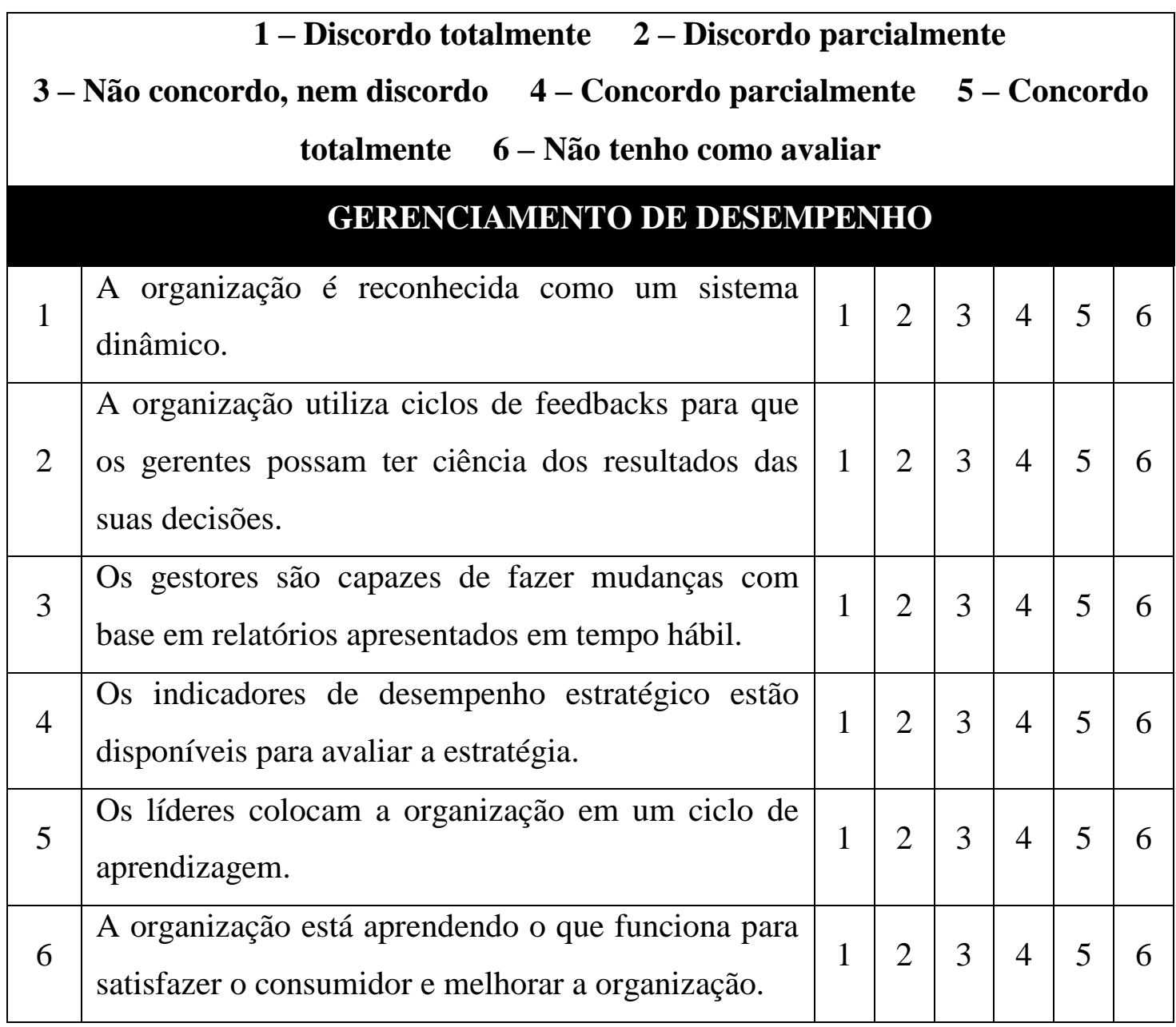

Quais são as dificuldades que sua organização enfrenta nessa dimensão? 
Quais seriam suas sugestões para que sua organização melhorasse o desempenho nessa dimensão?

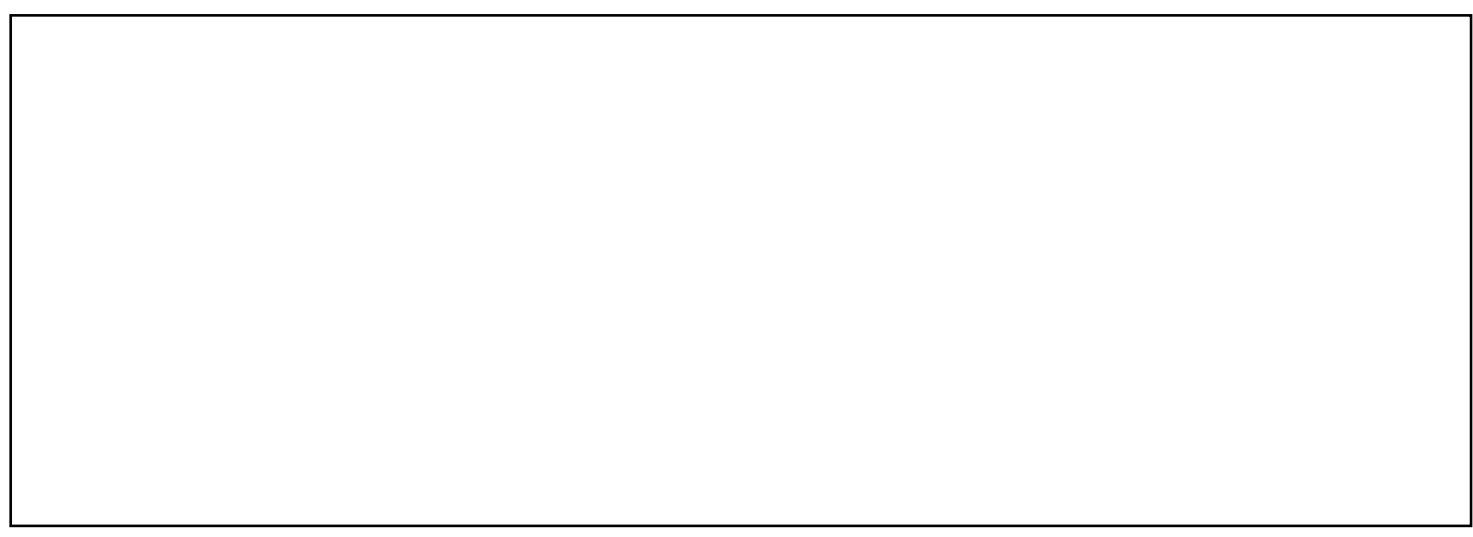

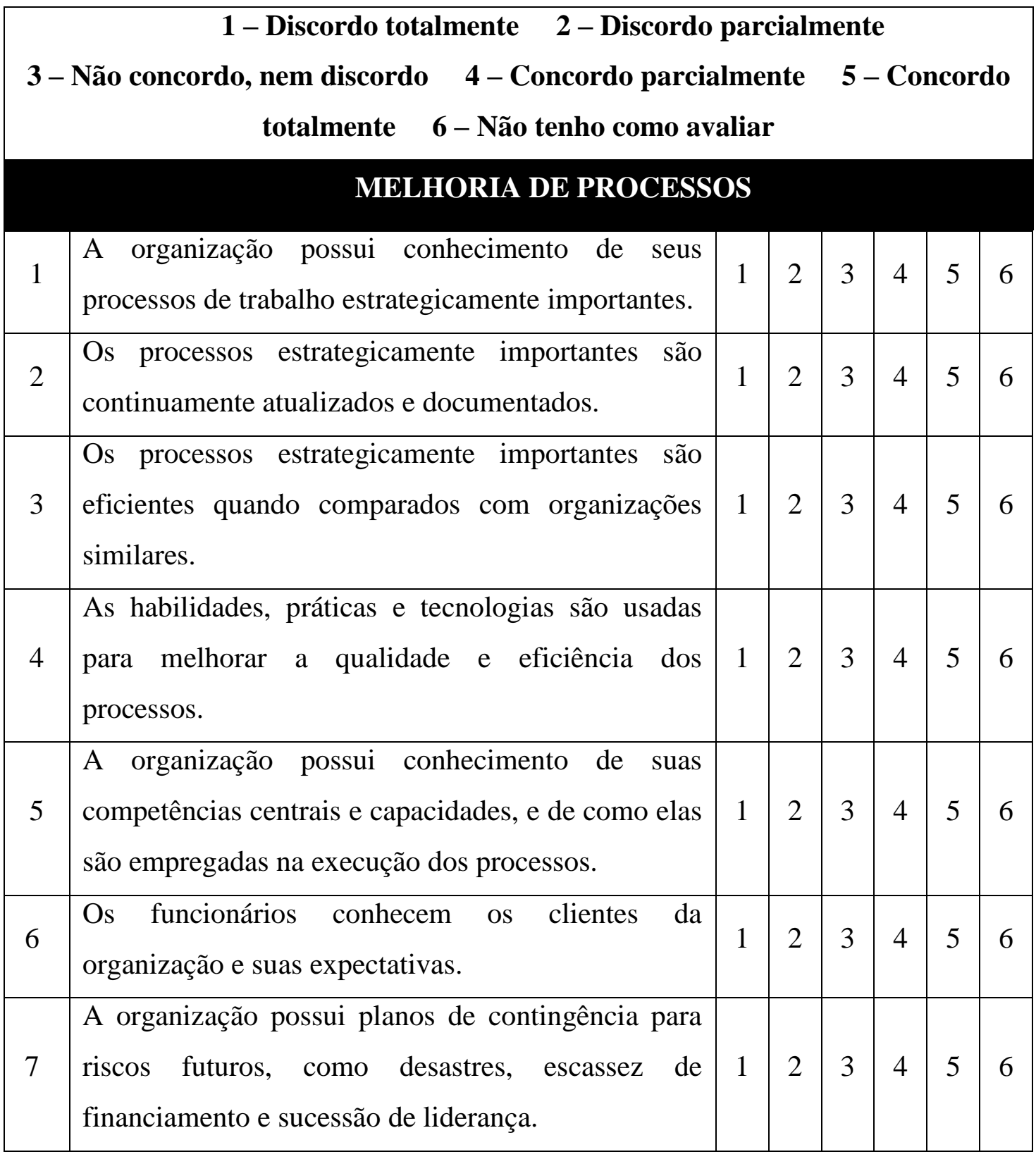


Quais são as dificuldades que sua organização enfrenta nessa dimensão?

Quais seriam suas sugestões para que sua organização melhorasse o desempenho nessa dimensão?

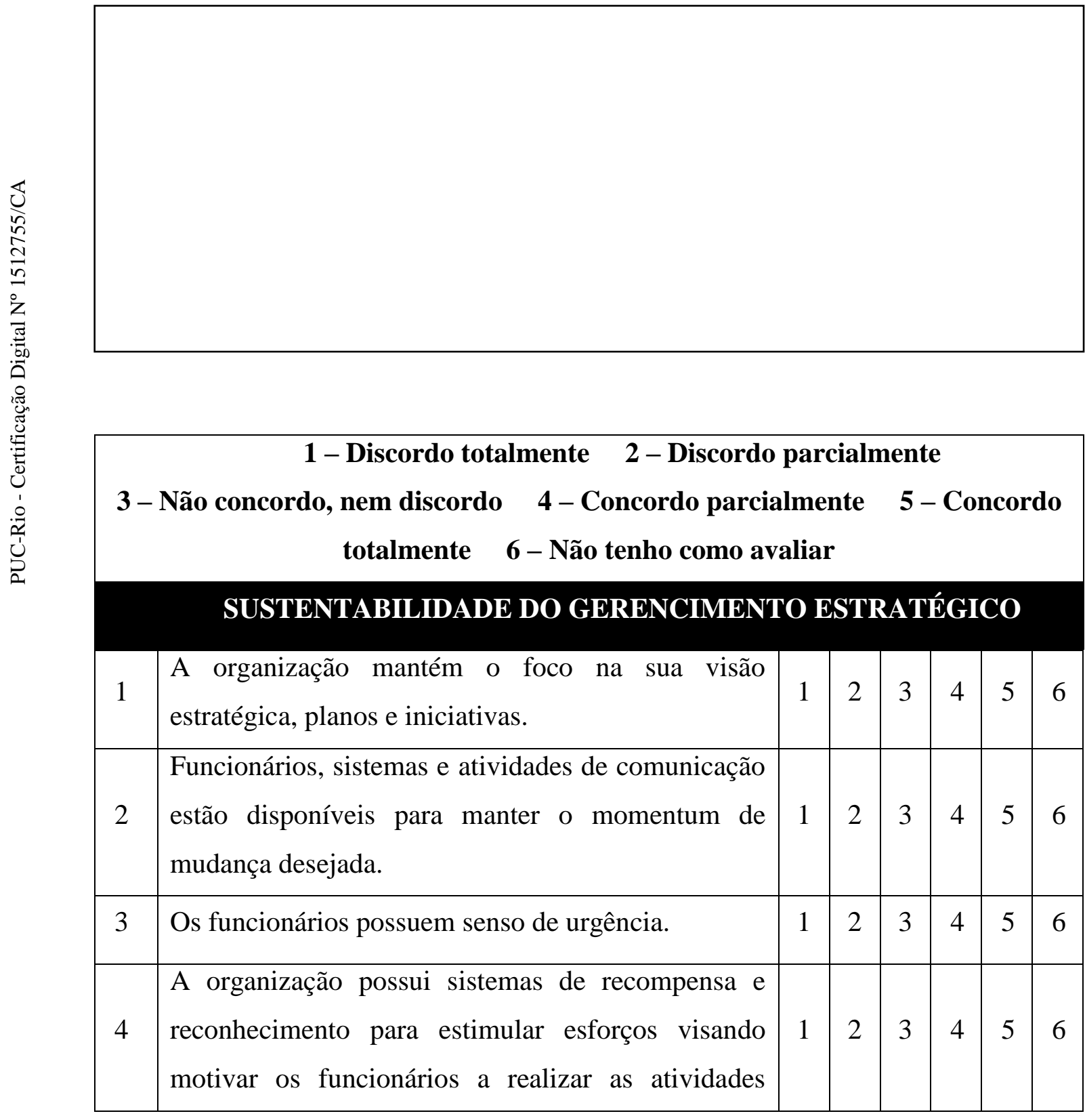




\begin{tabular}{|l|l|l|l|l|l|l|l|}
\hline & lorretas. & & & & & & \\
\hline 5 & $\begin{array}{l}\text { A organização possui líderes mobilizadores que } \\
\text { mantêm os funcionários informados sobre as } \\
\text { prioridades estratégicas e os níveis de desempenho } \\
\text { desejados. }\end{array}$ & 1 & 2 & 3 & 4 & 5 & 6 \\
\hline 6 & $\begin{array}{l}\text { A organização possui uma unidade de gestão } \\
\text { estratégica para implantar a estratégia e monitorar o } \\
\text { desempenho. }\end{array}$ & 2 & 3 & 4 & 5 & 6 \\
\hline 7 & $\begin{array}{l}\text { A organização possui uma gestão estratégica } \\
\text { institucionalizada, por essa razão, a estratégia é } \\
\text { considerada trabalho de todos. }\end{array}$ & 2 & 3 & 4 & 5 & 6 \\
\hline
\end{tabular}

Quais são as dificuldades que sua organização enfrenta nessa dimensão?

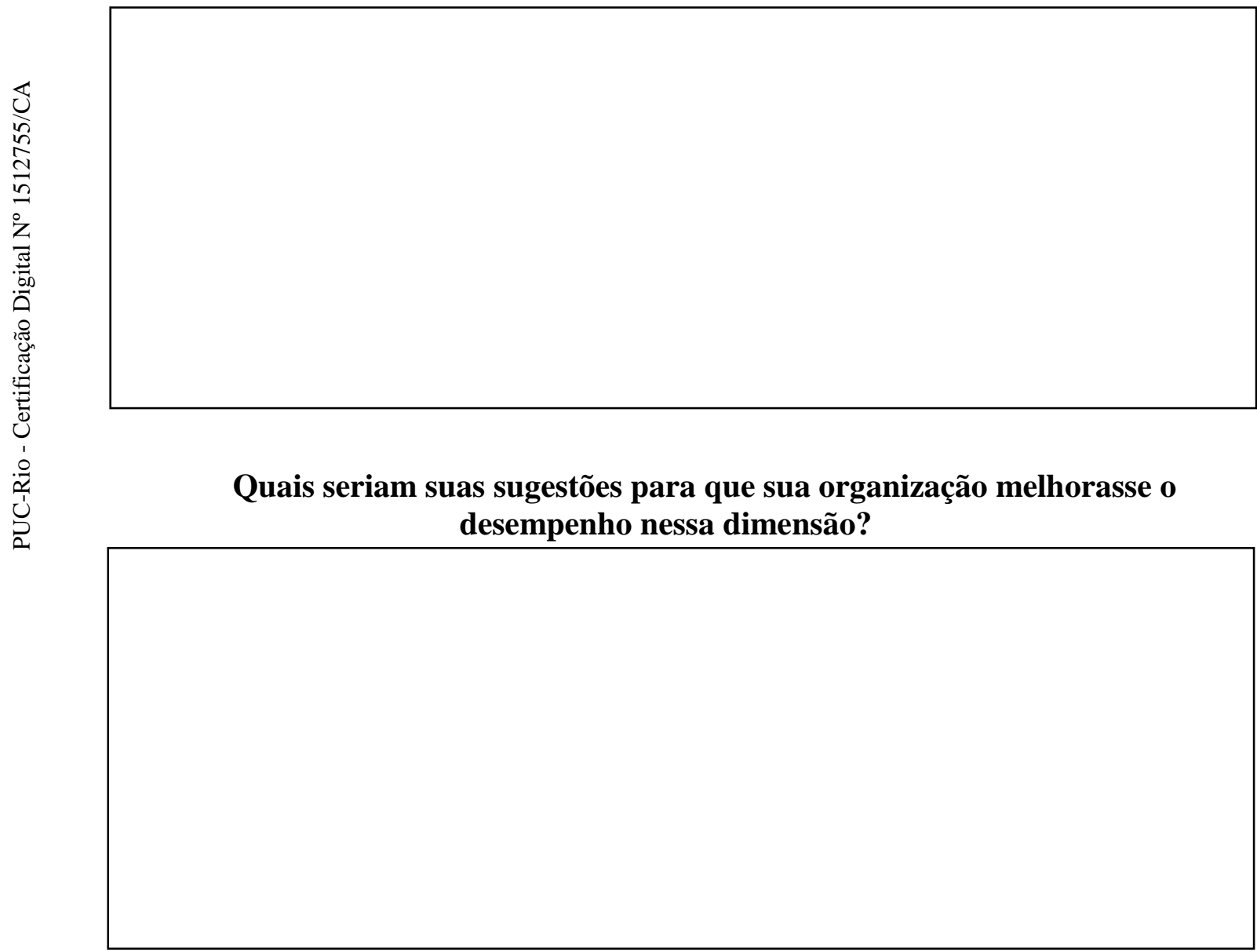

